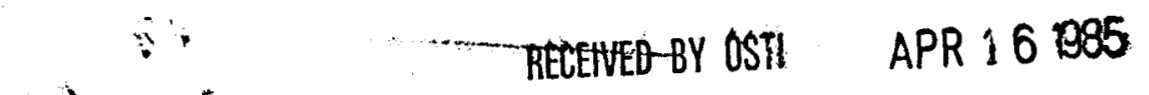

\title{
EXPERIMENTAL DETERMINATION OF THE EFFECTIVE TAYLOR DISPERSIVITY IN A FRACTURE
}

\author{
John R. Gilardi
}

DO NOT MICROFLM
COVER

June 1984

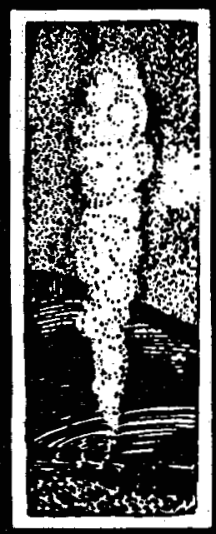

Stanford Geothermal Program INTERDISCIPLINARY RESEARCH

IN ENGINEERING AND EARTH SCIENCES Stanford University, Stanford, California 


\section{DISCLAIMER}

This report was prepared as an account of work sponsored by an agency of the United States Government. Neither the United States Government nor any agency Thereof, nor any of their employees, makes any warranty, express or implied, or assumes any legal liability or responsibility for the accuracy, completeness, or usefulness of any information, apparatus, product, or process disclosed, or represents that its use would not infringe privately owned rights. Reference herein to any specific commercial product, process, or service by trade name, trademark, manufacturer, or otherwise does not necessarily constitute or imply its endorsement, recommendation, or favoring by the United States Government or any agency thereof. The views and opinions of authors expressed herein do not necessarily state or reflect those of the United States Government or any agency thereof. 


\section{DISCLAIMER}

Portions of this document may be illegible in electronic image products. Images are produced from the best available original document. 
John R. Gilardi

June 1984

Financial support was provided through the stanford Geothermal Program under Department of Energy Contract No. DE-AT03-80SF11459 and by the Department of Petroleum Engineering, Stanford University. 


\section{TABLE OF CONTENTS}

LIST OF FIGURES.....................................................................11

LIST OF TABLES.....................................................................

INTRODUCTION ..........................................................................1

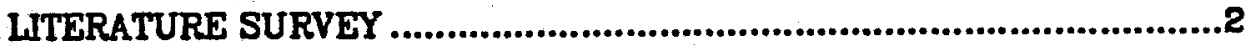

DESIGN

PROCEDURE ...........................................................................11

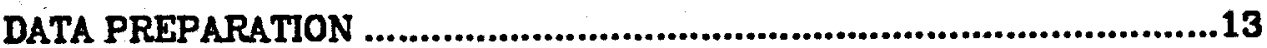

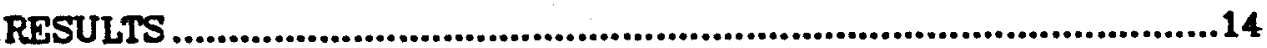

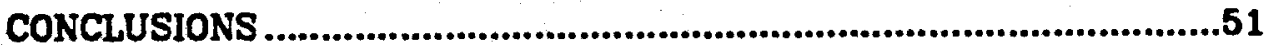

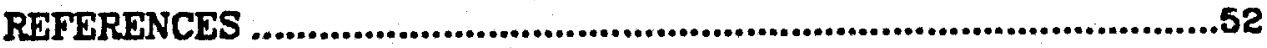

APPENDIX A: MULTIPLEXER BOARD ..........................................53

APPENDDX B: COMPUTER SCANNING ALGORITHMS.........................54

APPENDIX C: COMPUTER PROGRAMS AND SUBROUTINES..................55

\section{DISCLAIMER}

This report was prepared as an account of work sponsored by an agency of the United States Government. Neither the United States Government nor any agency thereof, nor any of their employees, makes any warranty, express or implied, or assumes any legal liability or responsibility for the accuracy, completeness, or usefulness of any information, apparatus, product, or process disclosed, or represents that its use would not infringe privately owned rights. Reference herein to any specific commercial product, process, or service by trade name, trademark, manufacturer, or otherwise does not necessarily constitute or imply its endorsement, recommendation, or favoring by the United States Government or any agency thereof. The views and opinions of authors expressed herein do not necessarily state or reflect those of the United States Government or any agency thereof. 


\section{IIST OF FTGURES}

1. Dispersion Schematics.......................................................................4

2. $\delta\left(t_{D}\right)$ vs. $t_{D}$ (Horne \& Rodriguez, 1983) ..........................................4

3. Hele-Shaw Cell: Overall view.........................................................7

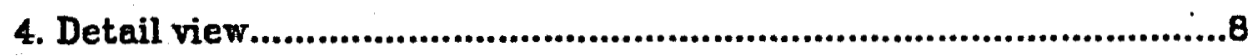

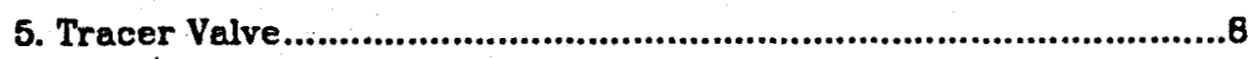

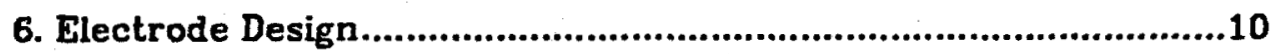

7. Reservoir Design ...............................................................................10

B. Comparison of Estimated and Calculated Dispersivity. Run $3 . \quad . .16$

9. Comparison of Estimated and Calculated Dispersivity. Run 4. ..21

10. Comparison of Estimated and Calculated Dispersivity. Run $5 . \quad 26$

11. Comparison of Estimated and Calculated Dispersivity. Run 7. .31

12. Comparison of Estimated and Calculated Dispersivity. Run 8.36

13. Comparison of Estimated and Calculated Dispersivity. Run 9. 41

14. Comparison of Estimated and Calculated Dispersivity. Run 10.46

A.1.1. Multiplexer Board Design..........................................................53

B.1.1. Computer Scanning Algorithms...............................................54 


\section{IIST OF TABLES}

1. Fracture Dimensions ..........................................................14

2. Measured Data .......................................................................14

3. Estimated Values ...............................................................15

4. Run 3 Results ..................................................................16

5. Run 4 Results ................................................................21

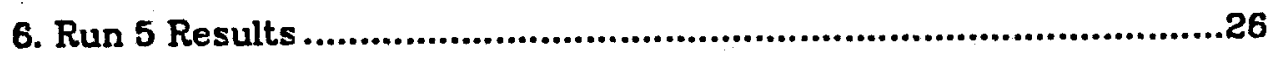

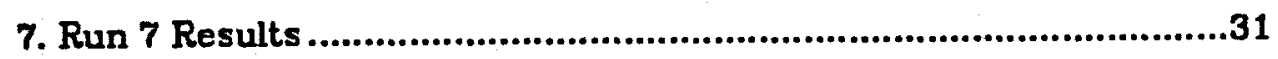

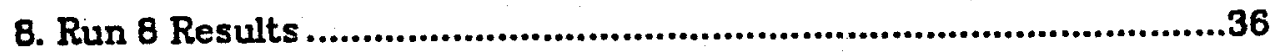

9. Run 9 Results .................................................................41

10. Run 10 Results ...............................................................46 


\section{Section 1: NTRODUCTION}

Reinjection of waste hot water is commonly practiced in most geothermal fields, primarily as a means of disposal. Surface discharge of these waste waters is usually unacceptable due to the resulting thermal and chemical pollution.

Although reinjection can help to maintain reservoir pressure and fluid volume, in some cases a decrease in reservoir productivity has been observed (Horne, 1982). This is caused by rapid flow of the reinjected water through fractures connecting the injector and producers. As a result, the water is not sufficiently heated by the reservoir rock, and a reduction in enthalpy of the produced fluids is seen.

Tracer tests have proven to be valuable to reservoir engineers for the design of a successful reinjection program. By injecting a slug of tracer and studying the discharge of surrounding producing wells, an understanding of the fracture network within a reservoir can be provided.

In order to quantify the results of a tracer test, a model that accurately describes the mechenisms of tracer transport is neccessary. One such mechanism, dispersion, is like a smearing out of a tracer concentration due to the velocity gradients over the cross section of flow. If a dispersion coefficient can be determined from tracer test data, the fracture width can be estimated.

The purpose of this project was to design and construct an apparatus to study the dispersion of a chemical tracer in flow through a fracture. 


\section{Section 2: LTEERATURE SURVEY}

The effects of water reinjection in geothermal systems worldwide is discussed in a paper by Horne(1983), which also includes a summary of tracer testing procedures and results.

In order to derive a model to accurately describe the transport of tracer through a fracture, the physics of dispersion must be understood. Taylor(1953) presented a classic study of dispersion in flow through a capillary tube. He showed that convective dispersion combines with transverse molecular diffusion in what we now know as "Taylor Dispersion" (Fig. 1). He showed that the tracer concentration is dispersed symmetrically about a plane that moves with the mean flow velocity. Taylor presents the equation governing the effective longitudinal dispersion:

$$
\eta \frac{\theta^{2} C}{\partial z^{2}}=\frac{\partial C}{\partial t}
$$

where,

$$
\begin{aligned}
& C=\text { concentration } \\
& z=\text { translated distance }=x \text {-ut } \\
& x=\text { distance } \\
& t=\text { time } \\
& u=\text { mean velocity of fow } \\
& \eta=\text { net longitudinal dispersivity (derived for pipe flow in Taylor's } \\
& \text { model) }
\end{aligned}
$$

The solutions to eqn (1) for different initial and boundary conditions can be found in Carslaw and Jaeger(1959). For a step input, 
found in Carslew and Jaeger(1959). For a step input,

$$
C=C_{0}+\frac{1}{2}\left(C_{1}-C_{0}\right)\left[\operatorname{erfc}\left(\frac{x-u t}{2(\eta t)^{1 / 2}}\right)+\exp \frac{u x}{\eta} \operatorname{erfc}\left(\frac{x+u t}{2(\eta t)^{1 / 2}}\right)\right]
$$

where,

$$
\begin{aligned}
& C_{0}=\text { base concentration } \\
& C_{1}=\text { injected concentration } \\
& C=\text { concentration at } x \\
& \text { erfe }=\text { complimentary error function }
\end{aligned}
$$

Horne and Rodriguez(1883) used a method similar to Taylor's to derive an expression for the net longitudinal dispersivity. $\eta$, for flow in a fracture:

$$
\eta=\frac{2}{105} \frac{b^{2} u^{2}}{D}
$$

where,

$$
\begin{aligned}
& \mathbf{b}=\text { fracture half-width } \\
& \mathbf{u}=\text { mean flow velocity } \\
& D=\text { coefficient of molecular diffusion }
\end{aligned}
$$

They also showed that, due to the effects of transverse molecular diffusion, any concentration gradients across the fracture would be equalized after a nondimensional time, $t_{D}=0.5$ (Fig. 2), where

$$
t_{D}=\frac{D}{b^{2}} t
$$

Fossum and Horne(1982) show how the subroutine VARPRO can be used to determine both linear and non-linear parameters from a set of experimental data. VARPRO uses a non-linear least squares method of curve fitting. ${ }^{12}$ Fossum and Horne(1982) matched the calculated response to field data from tracer 


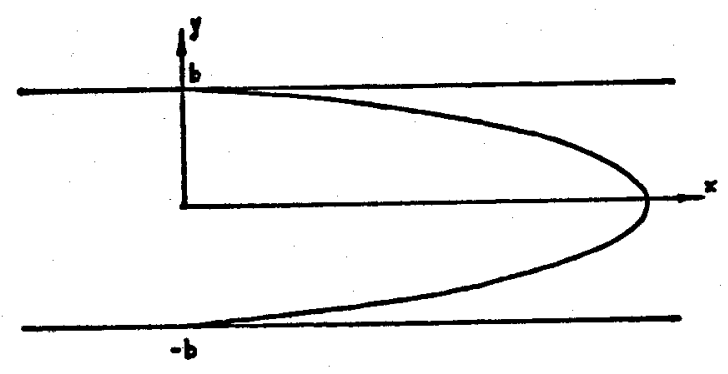

convective dispersion

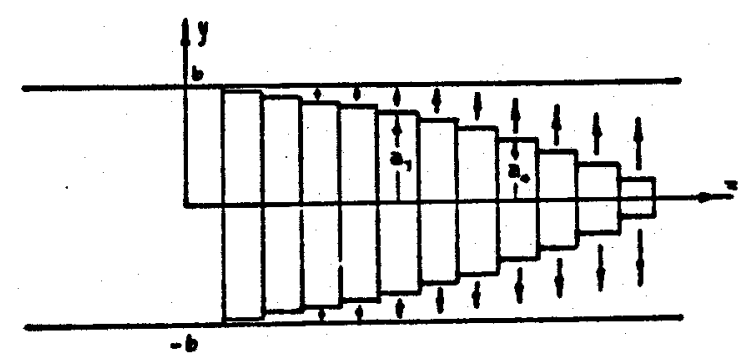

Taylor disperaion

(convective dispersion + transverse difusion)

Fig. 1. Dispersion Schematics

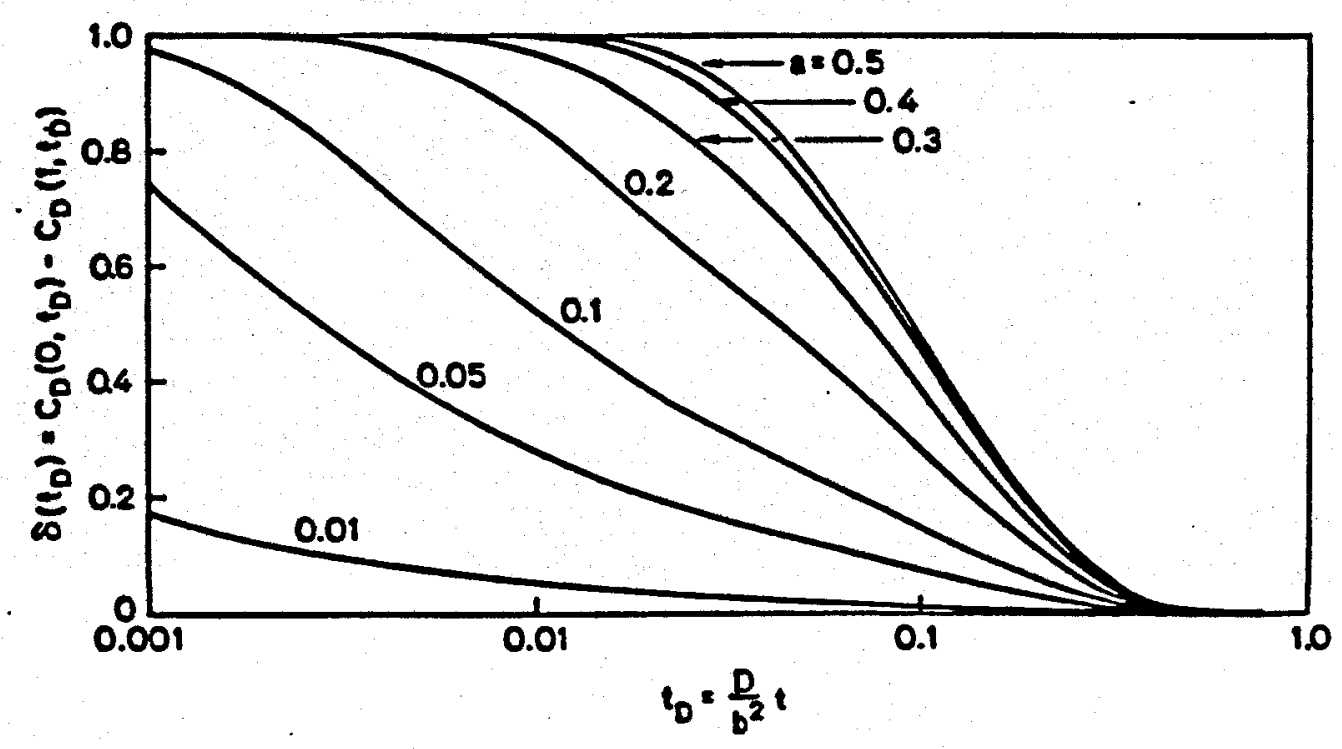

Fig. 2. $\delta\left(t_{d}\right)$ vs. $t_{d}$ (Horne \& Rodriguez, 1983) 
The present study set out to examine and confirm the applicability of Equation (3), which is only approximate, and to initiate broader investigations into dispersion in fractures. To these ends, an experimental program was undertaken.

The results of several experiments to study dispersion were found in the literature. Bear(1961) performed both one- and two-dimensional studies of dispersion through porous media and produced results which agreed with his theory. Hull and Koslow(1982) present the results of a study of dispersion in a network of chennels. 


\section{Section 3: DESTGN}

The design objectives were aimed at building an apparatus capable of studying dispersion through a fracture in both one- and two-dimensions. The possibility of testing both chemical and fuorescent tracers was another requirement.

\section{HELE-SHAW CELL}

The size of the model fracture, particularly its aperture, was constrained by the results of Horne and Rodriguez (1983). Any concentration gradient across the width of the fracture will be equalized after a non-dimensional time, $t_{D}=0.5$ (Fig. 2). The real time it takes to become equalized is proportional to the square of the fracture half-width:

$$
t=\frac{0.5 b^{2}}{D}
$$

Using a diffusion coefficient for potassium iodide $(K I) \simeq 2 \pi 10^{-9} \mathrm{~m}^{2} / \mathrm{sec}$ and a fracture half-width of $0.25 \mathrm{~mm}$, the time required is about $16 \mathrm{sec}$. By using an aperture of $0.54 \mathrm{~mm}$ and flowrates of approximately $50 \mathrm{cc} / \mathrm{min}$ we could keep the apparatus small enough to fit on a lab bench! The cell is $6 \mathrm{ft}$ long by $1 \mathrm{ft}$ wide. Fig. 3 shows an overall view and Fig. 4 a detail of the design.

The lower plate is $1 \mathrm{in}$. thick cast aluminum alloy. It is hard anodized to prevent corrosion and provide a tough, non-conductive finish. The upper plate is $1 / 4$ in. float glass and is separated from the aluminum by gasket made up of three layers of plastic electrical tape. A series of aluminum clamps holds the cell together while four adjustable legs support it horizontally on the lab bench.

\section{VALVES}

The inlet and outlet ports were implemented by drilling holes 11 in. through the width of the plate. A 0.25 in. slit was then sawed through the surface (Fig. 4) Since the pressure drop across the length of the drilled hole is negligible com- 


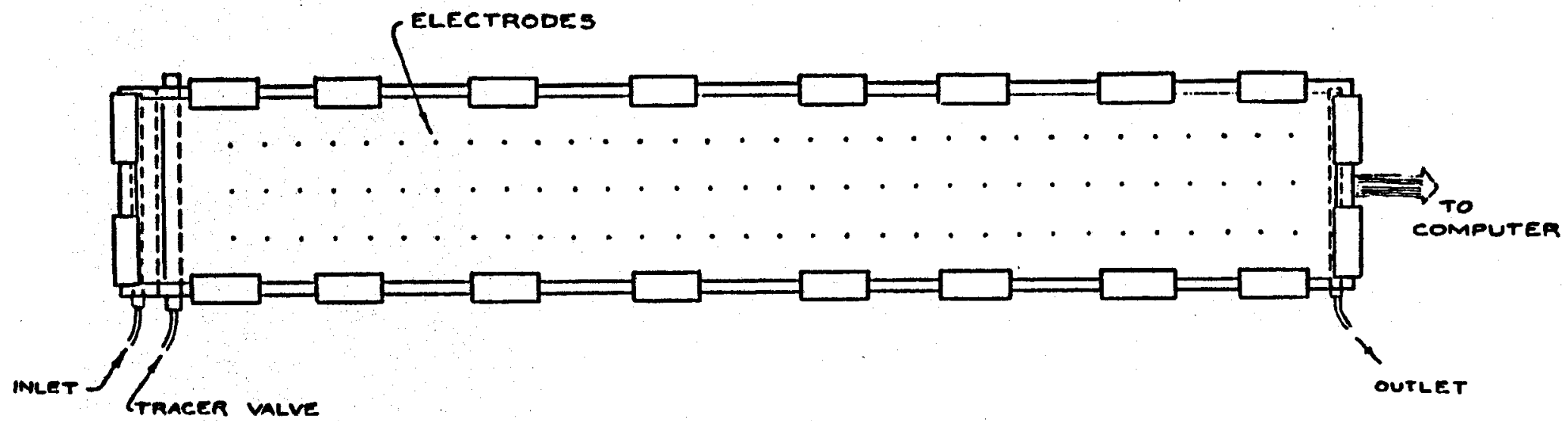

TOP VIEW

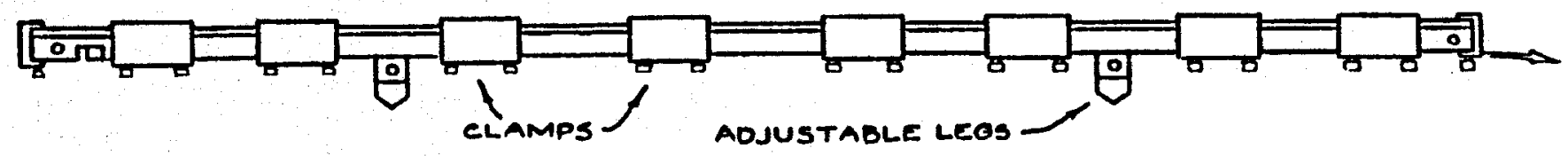

SIDE VIEW

FIG. 3 HELE- SHAW CELL

IFT. 
$\therefore$

$=$

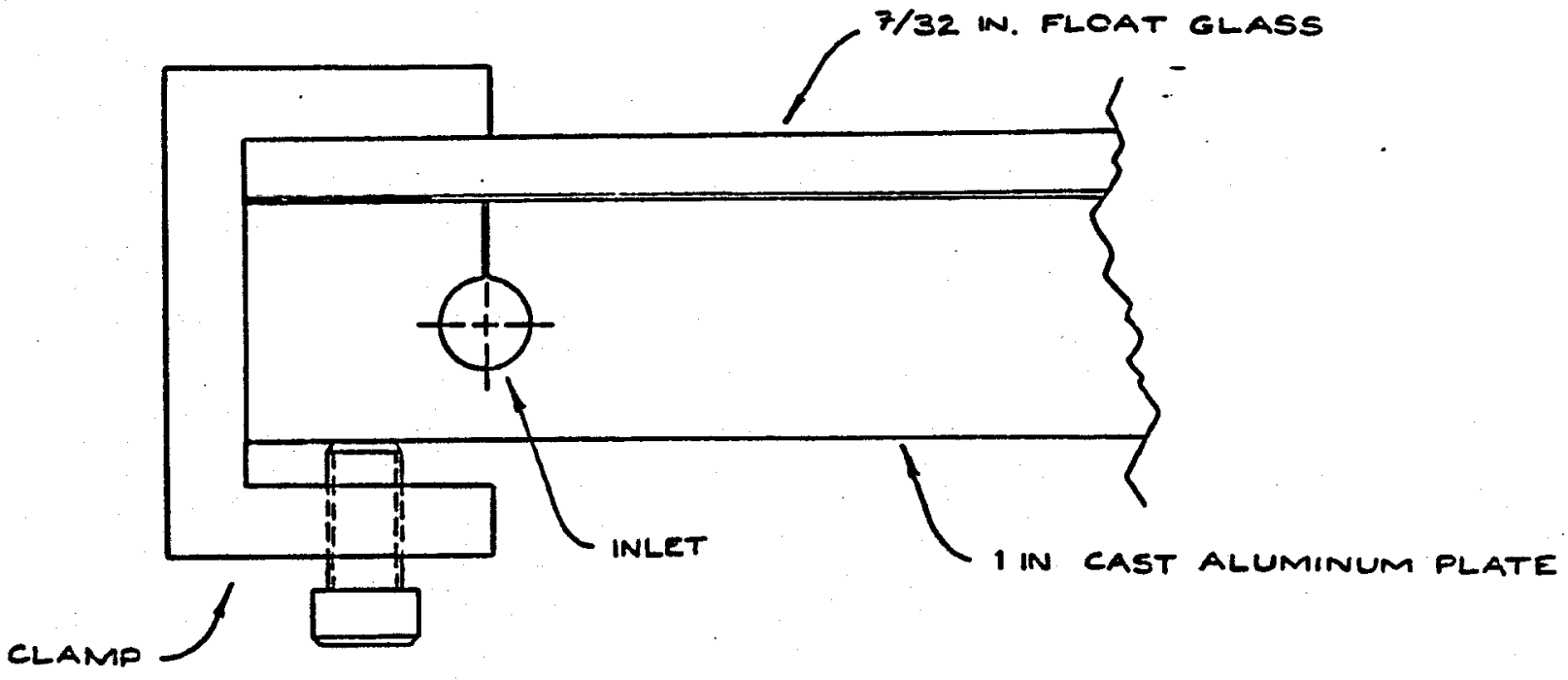

FIG. 4. DETAIL VIEW

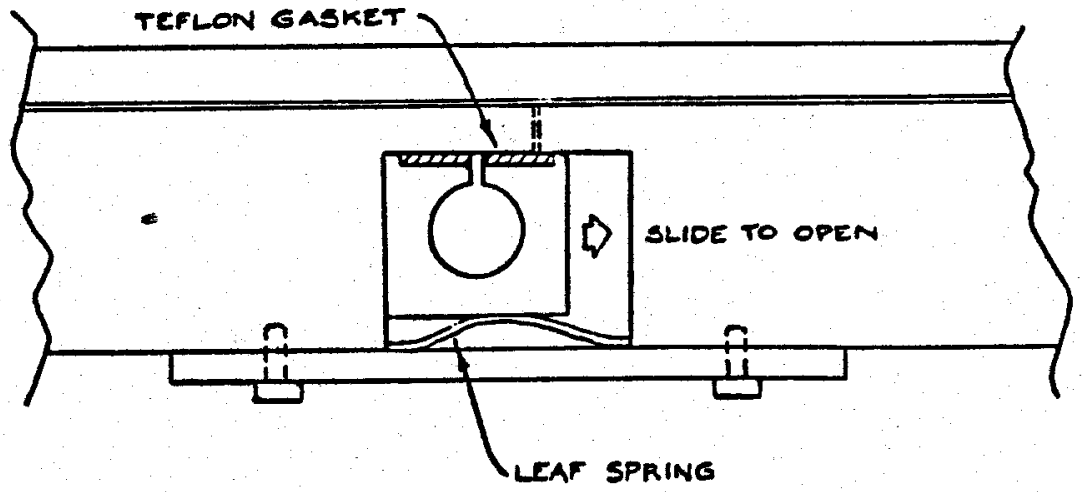

fig. 5. tracer valve 
pared with that across the slit, water will thow into the cell at uniform velocity over its width.

An on-off valve (Fig. 5) was designed to allow instantaneous injection of tracer. The valve is activated by hand and can be locked in either on or off position.

\section{ELECTRODES}

In order to continuously monitor the tracer concentration as it flows through the cell, an array of 96 electrodes was employed. For a KI tracer the conductivity of solution will increase linearly with the log of concentration. Thus we are able to measure the tracer concentration at any electrode location and any chosen time.

The coaxial electrodes were constructed using brass conductive elements and a teflon insulator (Fig. 6). The brass surfaces were electroplated with gold to prevent corrosion and polarization. Each electrode is press fit in to the aluminum plate and mounted tat to within .0015 in. The central electrode is connected to the data equisition system, and the outer electrode is grounded to the plate.

An instantaneous current is flowed across the electrode while the resulting voltage is measured (requiring less than $0.1 \mathrm{sec}$.). Voltages can be measured once each second and are stored in Compaq personal computer. The date is displayed on the screen so it is possible to "watch" the tracer as it flows through the cell. The curcuitry and electronics are described in Appendix A, and the computer scanning algorithms are described in Appendix B.

\section{CONSTANT FLOWRATE SOURCE}

Two constant pressure reservoirs, one for the base concentration and one for the tracer, were constructed (Fig. 7). The tlowrate can be adjusted by 
changing the height of the center tube.
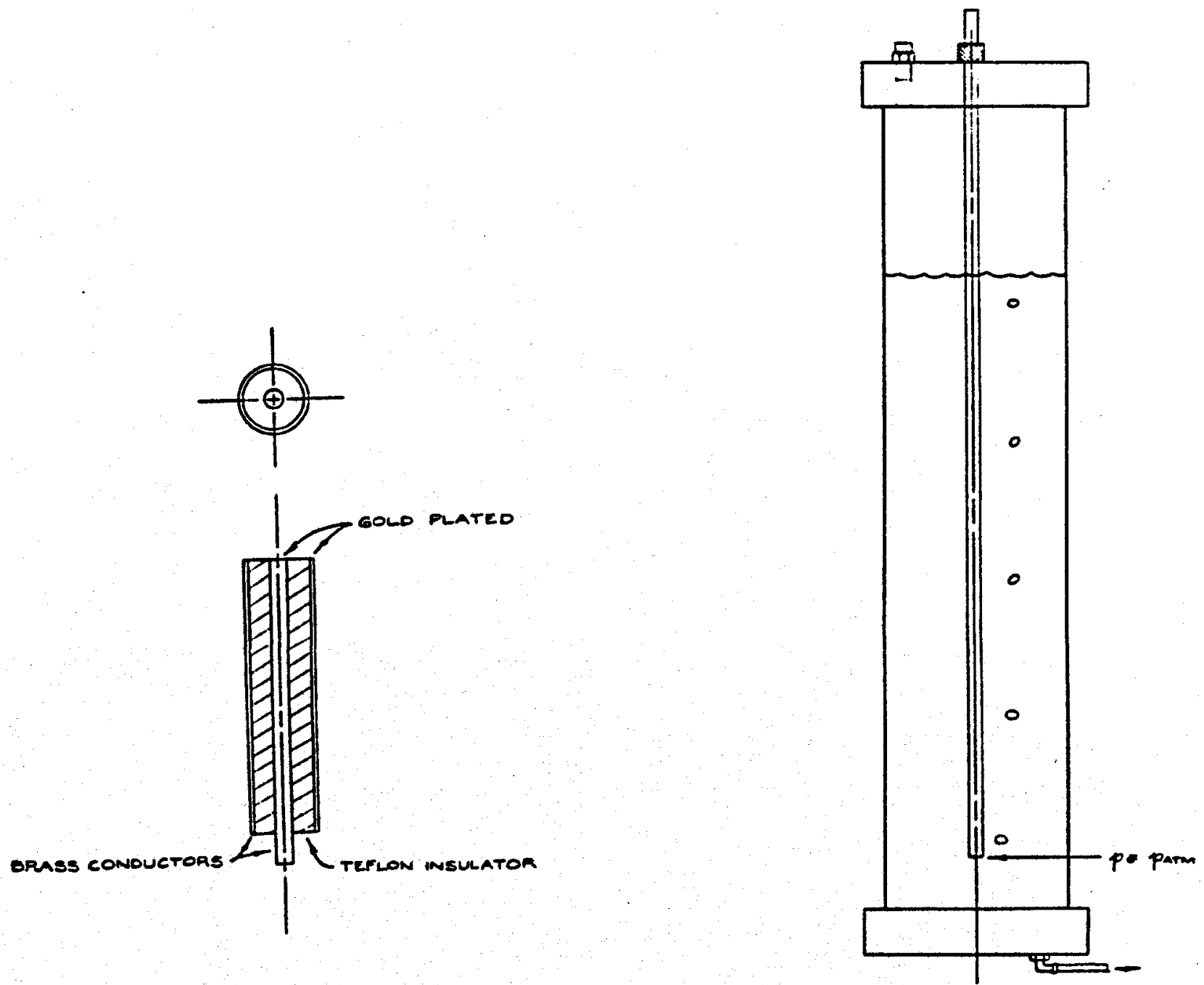

FiG. 6 CLECTRODE DESION W/210. 


\section{Section 4: PROCEDURE}

I. Solution Preparation

(a) Prepare solutions of desired concentrations using distilled water and iodide standard. A base concentration of 175-200 ppm should be used. Voltage readings from lower concentrations tend to be too unstable for accurate analysis. By injecting $\sim 300$ ppm the electode response remains in the linear portion of the voltage vs. log concentration curve. thus simplifying analysis. Using the $1000 \mathrm{ml}$ volumetric flask, the concentration is:

$$
C(p p m)=\frac{(x) \text { liter of iodide standard }-12690 \mathrm{mg} / \mathrm{l}}{1 \text { liter }}
$$

(b) Clean reservoirs and fill with solution.

II. Assembly

(a) Wipe clean the aluminum and glass plates with wet sponge and assemble; clamps should be finger tight.

(b) Flush the Hele-Shaw cell with $\mathrm{CO}_{2}$ (at $\mathrm{p}<2$ psi or glass may shatter).

(c) Begin flowing water slowly, making sure to clear both the inlet and tracer valve of air, otherwise bubbles will become trapped in the cell. (distilled water was flowed until the cell was void of all air bubbles to save the prepared solutions for test experimental runs.) Pounding on the glass with the butt of your hand, or tapping the glass with the rubber mallet while flowing at high rate can prevent the water front from fingering and forming air pockets.

(d) Now start flowing the solution of base concentration; allow 2 pore volumes $(\sim 500 \mathrm{cc}$ ) to flow before starting to SCAN (see next step).

III. Prepare computer for run 
(a) Plug in the multiplexor board power supply (Appendix A describes the design and operation of the multiplexor): turn on printer, then computer.

(b) When "clock" appears ( 60 sec) hit 〈F10〉.

(c) Type b:

(d) Remove system diskette from the A drive; replace with a blank diskette.

IV. Ready to run

(a) To begin recording, enter SCAN. Note time. SCAN will measure and store the voltage at each electrode, once per second, and will fill the C (internal) diskette after about $7 \mathrm{~min}$. The voltages will be plotted against the location of each electrode on the screen (they will vary for each electrode since each has different sensitivity): SCAN will stop automatically after $7 \mathrm{~min}$. or sooner if you hit $\langle\mathrm{F} 1\rangle$.

(b) Allow base concentration to flow for $\sim 1 \mathrm{~min}$. before injecting tracer. To inject, open gate valve, slide tracer valve into position and shut off inlet valve. Record time of injection.

(c) When run is over, enter FIXUP. FIXUP processes the data ( 15 min) and stores it in a new file named labfix.dat on the A diskette.

(d) Enter PLOTFIX. This plots the voltage vs. time for each electrode, individually.

(e) Take diskette out and lebel it; these are your results.

(f) To start a new run, insert a blank disc in the a drive, shut off the tracer, and flow the base concentration ( $500 \mathrm{cc})$. Repeat steps 7-11.

(g) After runs are finished, disassemble and wash down thoroughly. Unplug the multiplexor board, shut off computer and printer. 


\section{Section 5: DATA PRBPARATION}

The processed data (labfix.dat) can be matched to the model given by Equation (2) to provide estimates of the mean speed of flow (u), and the effective dispersivity $(\eta)$. A FORTRAN program, CURVEFIT, performs this operation, and simultareously calibrates the measured voltages to concentrations. The program is run as follows:

(a) Copy labfix.dat from drive $A$ to drive $C$ ( $C$ must be erased first).

(b) Create a file PARAMS on $\mathrm{C}$ as follows:

1. $\quad N=$ number of unknowns (I2). $\left[=2\right.$ ( $u$ and $\eta$ ), can be 3 if $t_{c}$ is unknown as well].

2. Initial estimates of $u, \eta$; one per line (F10.4).

3. Base concentration $\left(C_{0}\right)$ and injected concentration $\left(C_{1}\right)$ : one per line (F10.4).

4. Number of electrodes to be analyzed and electrode numbers (40I2); e.g. 080104052122232932 will analyze 8 electrodes $-1,4,5,21,22,23,29$ and 32.

(c) Load a blank diskette in drive $\mathrm{A}$.

(d) Type a:

(e) Type b:curvefit

(f) Type c: params <CR>, con <CR>, c:labfix.dat <CR>, prn <CR>.

(g) The program will output a summary of estimated parameters on the printer, and will create output files (1.dat through 32.dat) on A. These may be used for plotting. The program takes several hours to run.

(b) On completion, type b:plot, this will plot the results on the screen for a specified range of electrodes. 


\section{Section 6: RESULTS}

The results of seven one-dimensional experiments are presented in this section. The results from CURVEFIT are displayed in Tables 4-10, and are compared with the dispersivity predicted by Equation (3) in Figures 8-14. Graphs of the data collected from each electrode and the curve that fits it are also presented. Since it was a one-dimensional study, only the central row of 32 electrodes was used.

The actual fracture dimensions are shown in Table 1. Since the glass plate used for thes runs was slightly curved, the aperture was measured at the centerline.

\begin{tabular}{|c|c|c|}
\hline \multicolumn{3}{|c|}{ Table 1. FRACTURE DIMENSIONS (cm) } \\
\hline \hline Aperture & wldth & length \\
\hline 0.0515 & 24.46 & 179.1 \\
\hline
\end{tabular}

Table 2 shows the concentrations of the base, $\left(C_{0}\right)$, and injected $\left(C_{1)}\right.$ solutions for each run. The flowrate was measured by recording the time required to fill a $50 \mathrm{ml}$ flask at the outlet. The time of injection, $t_{0}$, was only recorded for runs 8,9 , and 10 .

\begin{tabular}{|c|c|c|c|c|}
\hline \multicolumn{5}{|c|}{ Table 2. MEASURED DATA } \\
\hline \hline Run \# & $C_{0}(\mathrm{ppm})$ & $C_{1}$ (ppm) & $q\left(\mathrm{~cm}^{9} / \mathrm{sec}\right)$ & $t_{0}$ (sec) \\
\hline 3 & 203 & 305 & 0.80 & - \\
4 & 203 & 305 & 1.25 & - \\
6 & 177 & 305 & 0.82 & - \\
7 & 177 & 305 & 1.38 & - \\
8 & 177 & 305 & 0.66 & 60 \\
9 & 177 & 305 & 0.48 & 42 \\
10 & 177 & 305 & 0.57 & 43 \\
\hline
\end{tabular}

The velocities listed in Table 3 are values from CURVEFIT that best match the data (since the fracture cross-section did not have constant aperture, the 
flow velocity was not constant over the width of the cell, and $u=q / A$ may not be accurate). These best-fit values are used in Equation (3) to provide an estimate of the dispersivity $(\eta)$. The estimated times of injection, $t_{0}$. used in PARAMS are also listed in Table 3.

\begin{tabular}{|c|c|c|c|}
\hline \multicolumn{4}{|c|}{ Table 3. ESTIMATED VALUES } \\
\hline \hline Run & $u(\mathrm{~cm} / \mathrm{sec})$ & $\eta\left(\mathrm{cm}^{2} / \mathrm{sec}\right)$ & $t_{0}(\mathrm{sec})$ \\
\hline 3 & 0.642 & 0.210 & 73.0 \\
4 & 0.824 & 0.486 & 56.6 \\
6 & 0.539 & 0.208 & 79.6 \\
7 & 0.890 & 0.567 & 73.4 \\
8 & 0.451 & 0.146 & 60.0 \\
9 & 0.375 & 0.101 & 42.5 \\
10 & 0.416 & 0.124 & 42.6 \\
\hline
\end{tabular}

The dispersivities predicted by Equation (3) are compared with those estimated by CURVEFIT in Figures 8-14. Only selected electrodes are plotted, as some are inconsistent due to faulty data collection or transmission. Electrodes 1 and 2 were usually inconsistent, probably because the tracer front had not yet become equalized. 


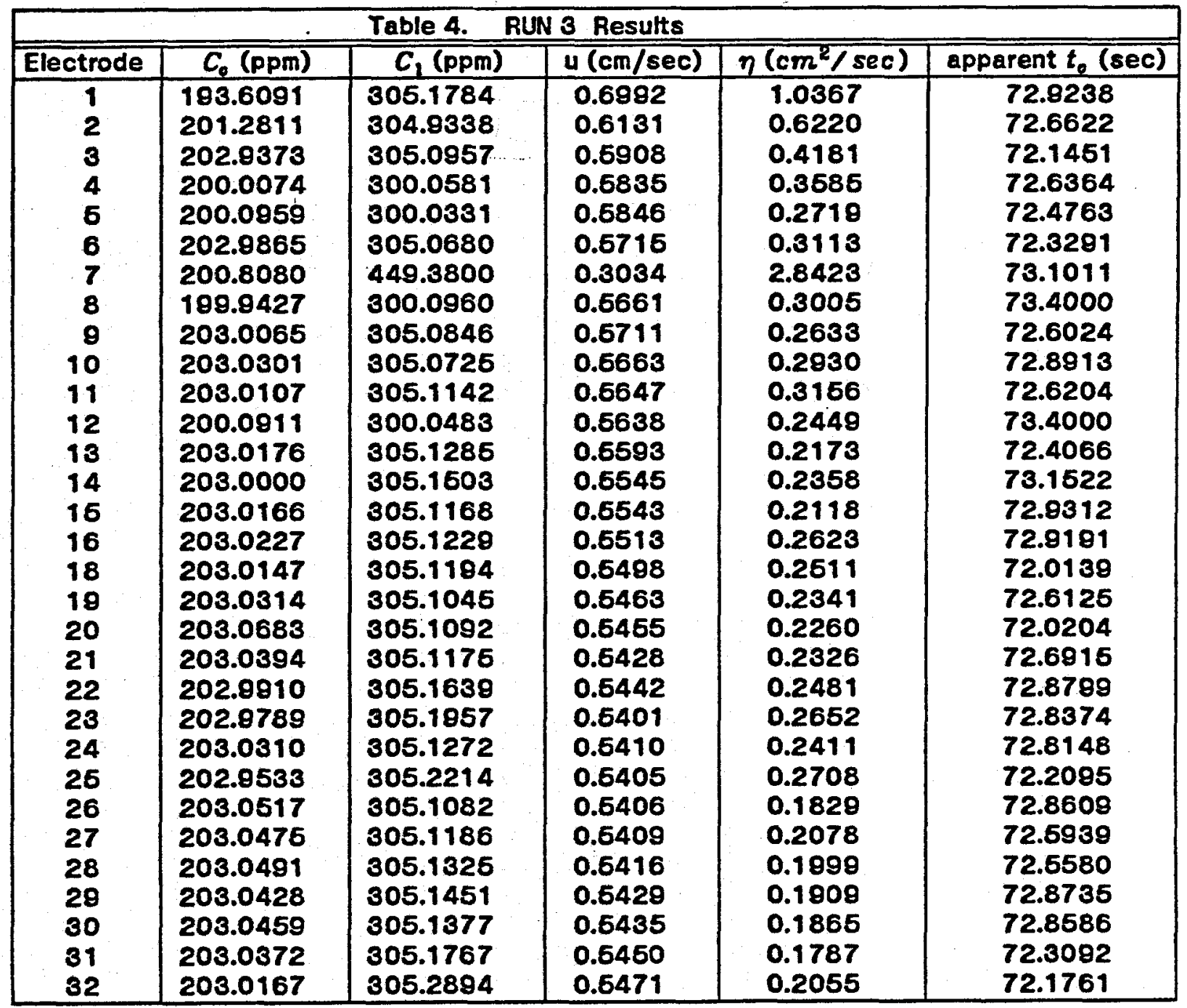

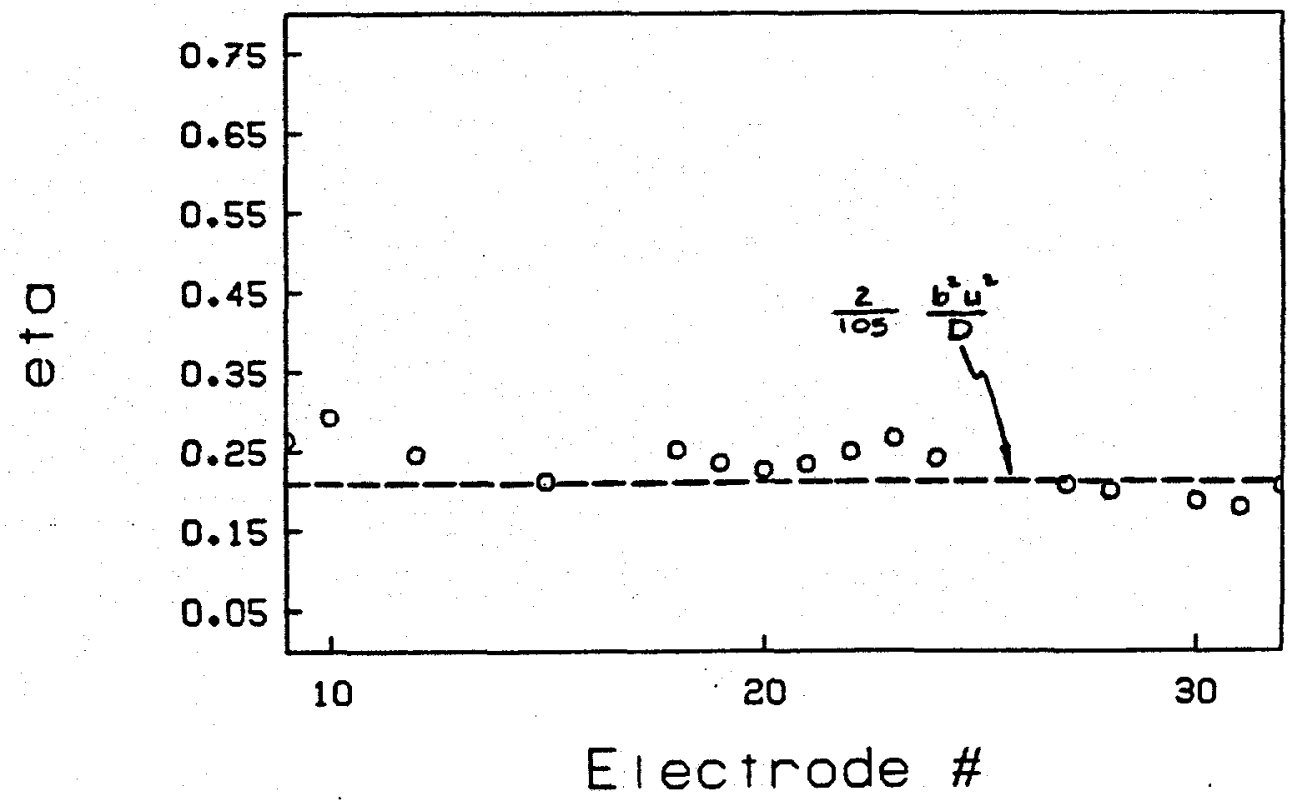

Fig. 8. Comparison of estimated and calculated dispersivity. Run 3. 

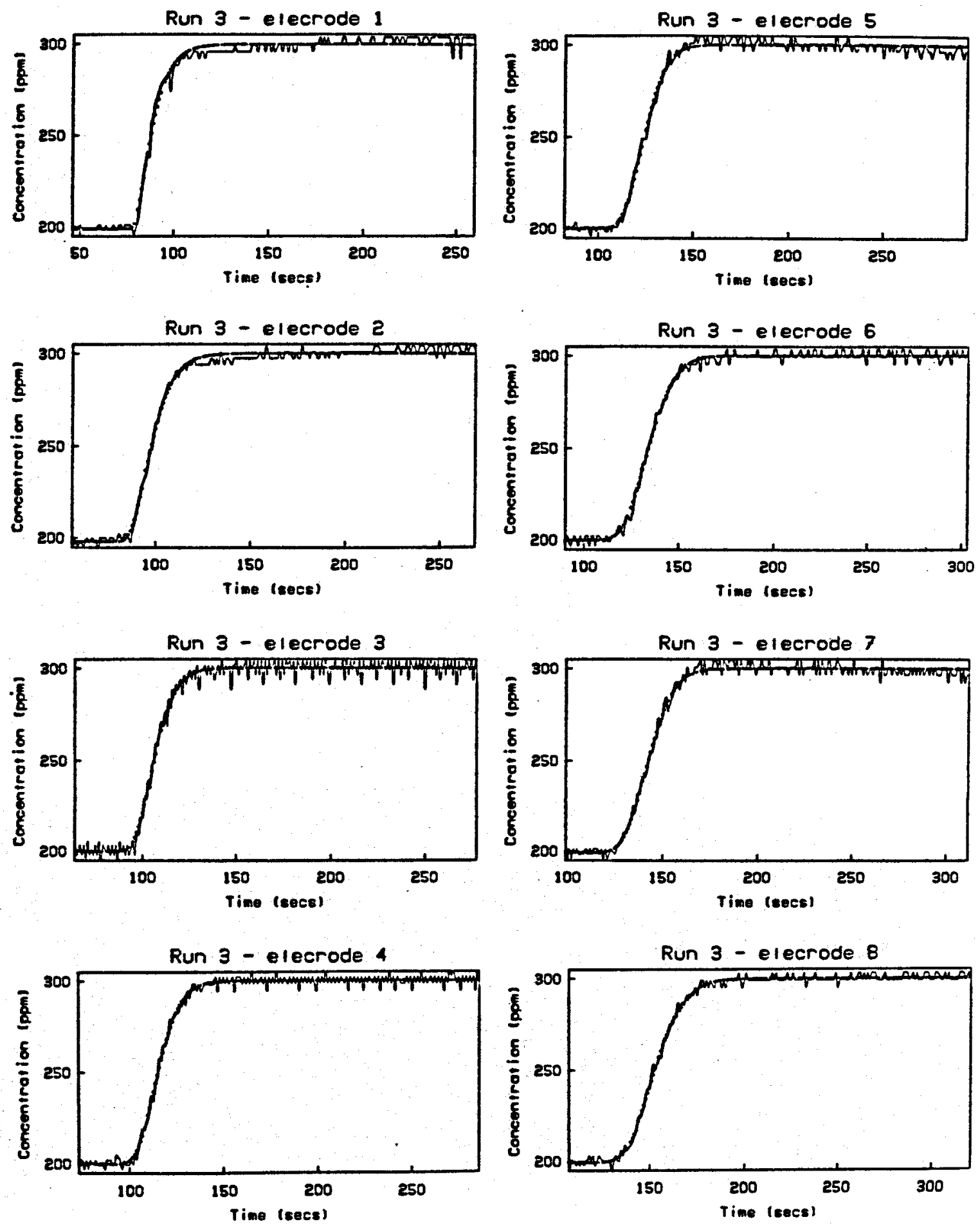

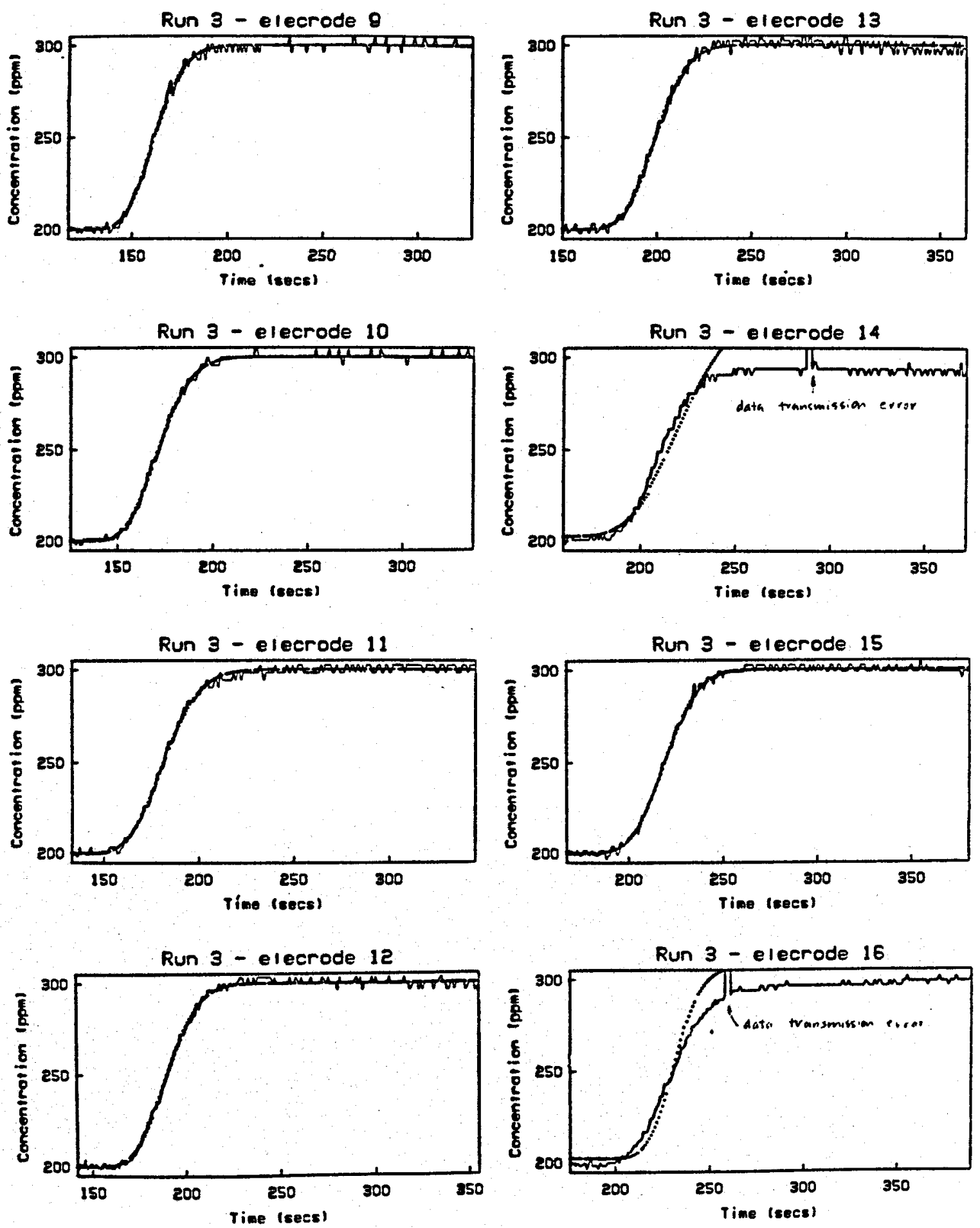

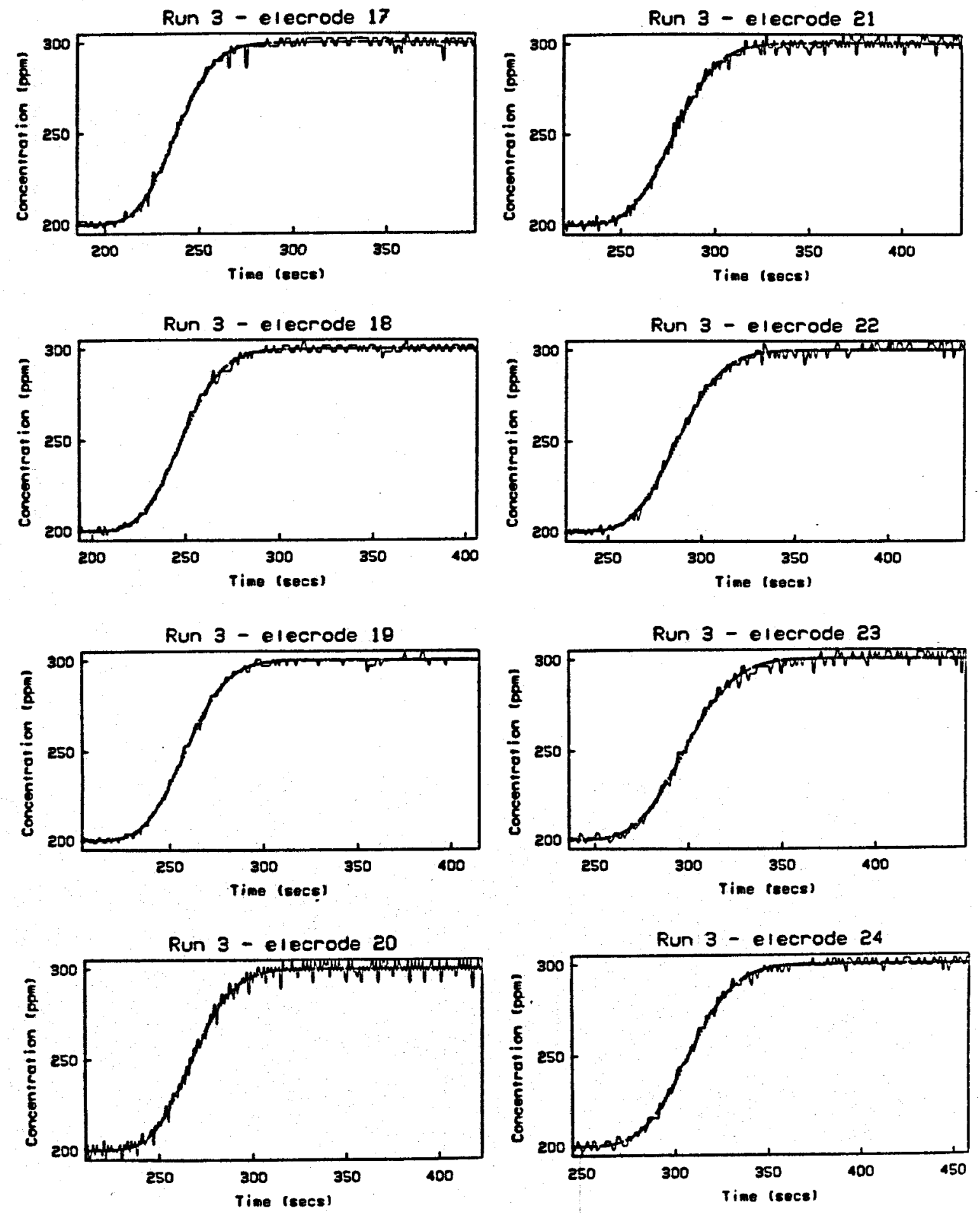

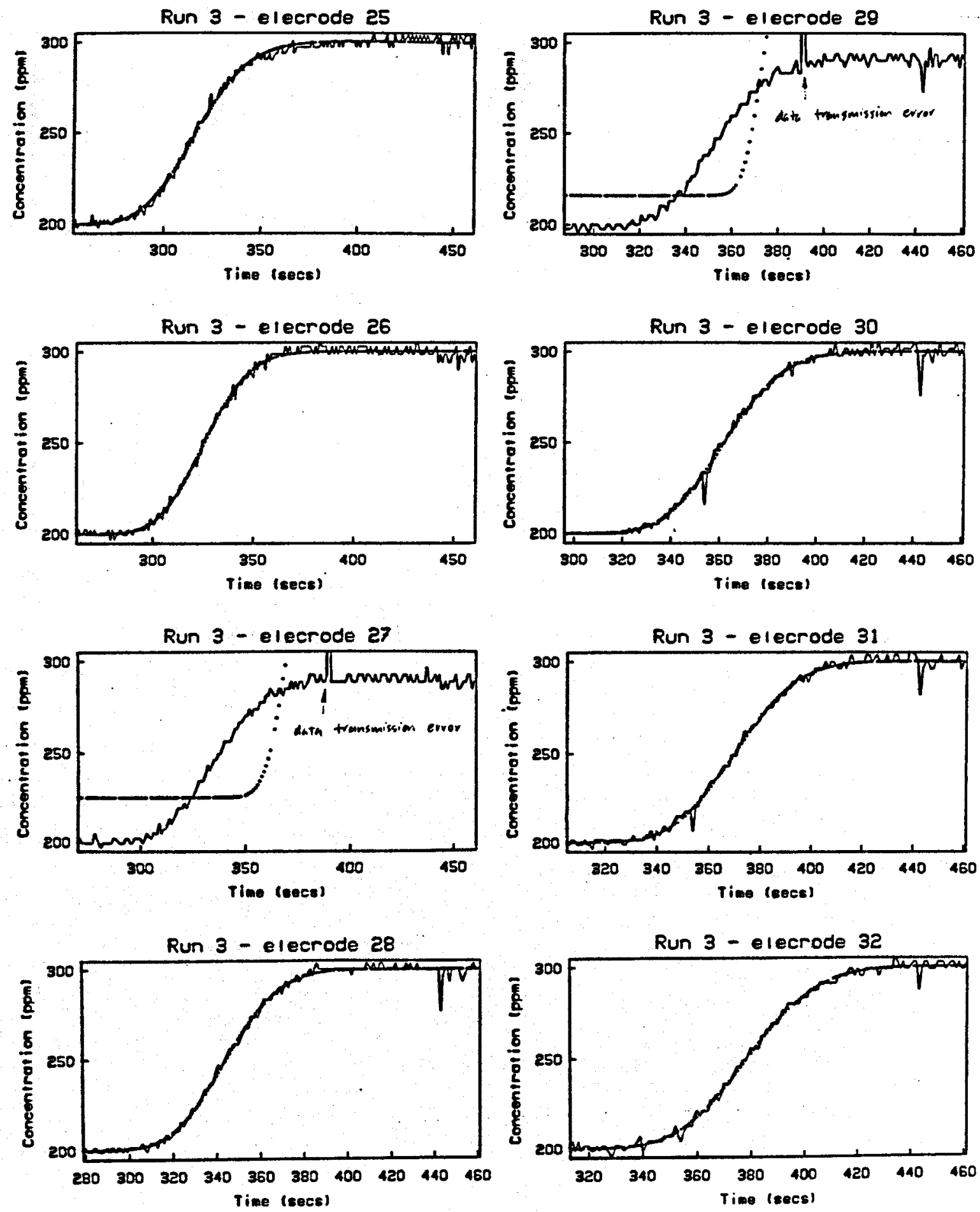


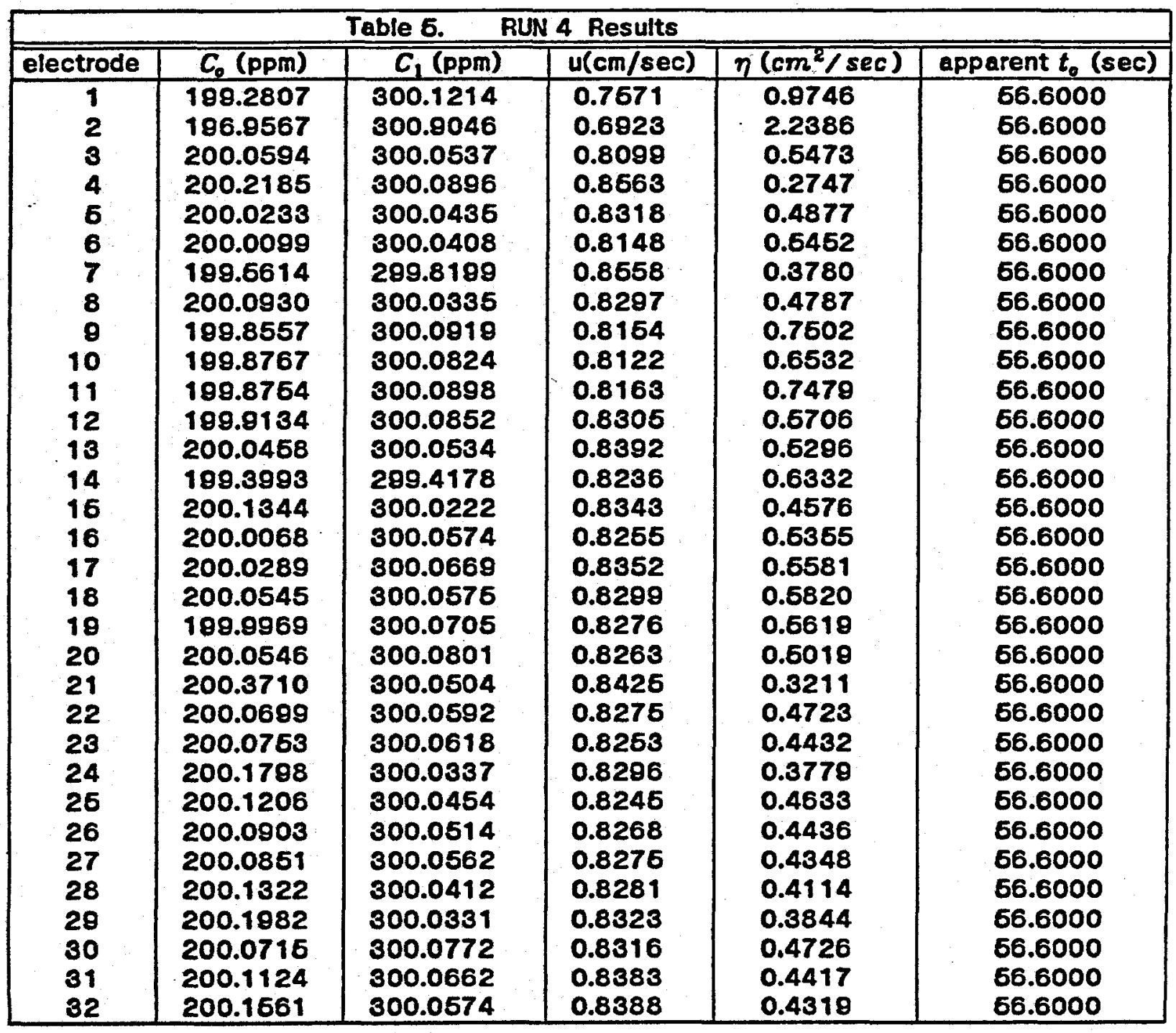

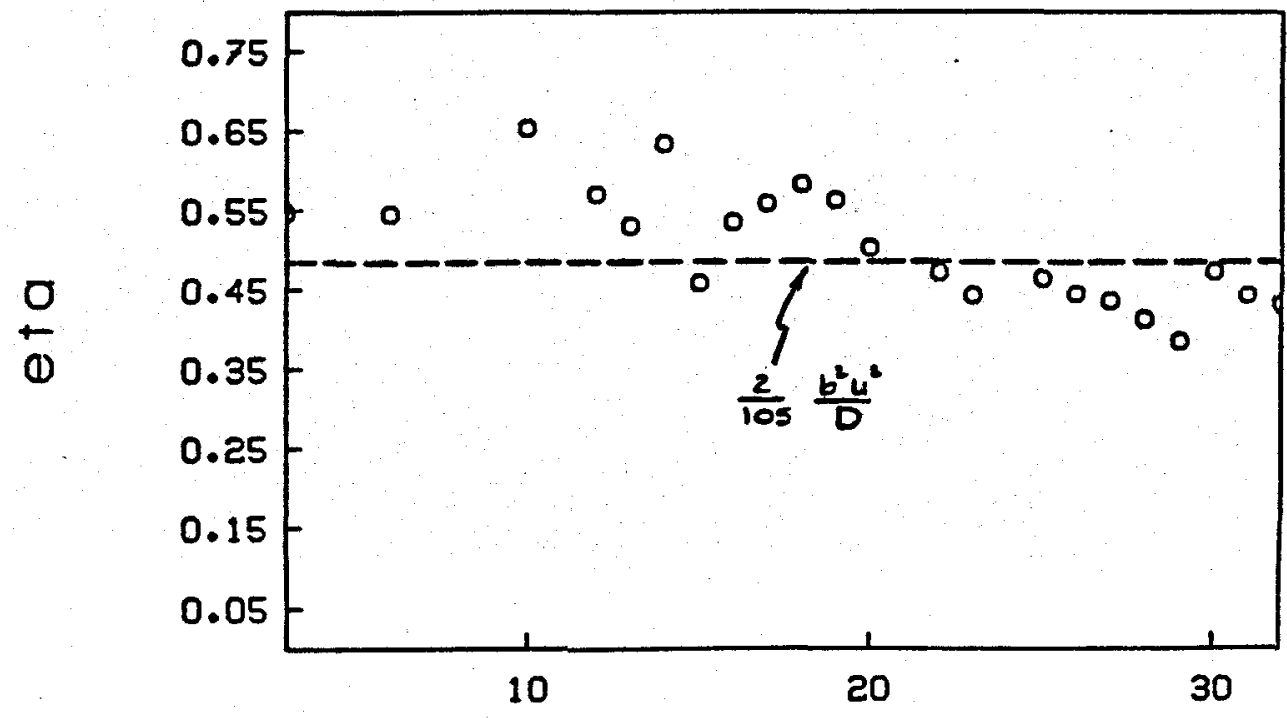

Electrode \#

Fig. 9. Comparison of estimated and calculated dispersivity. Run 4. 

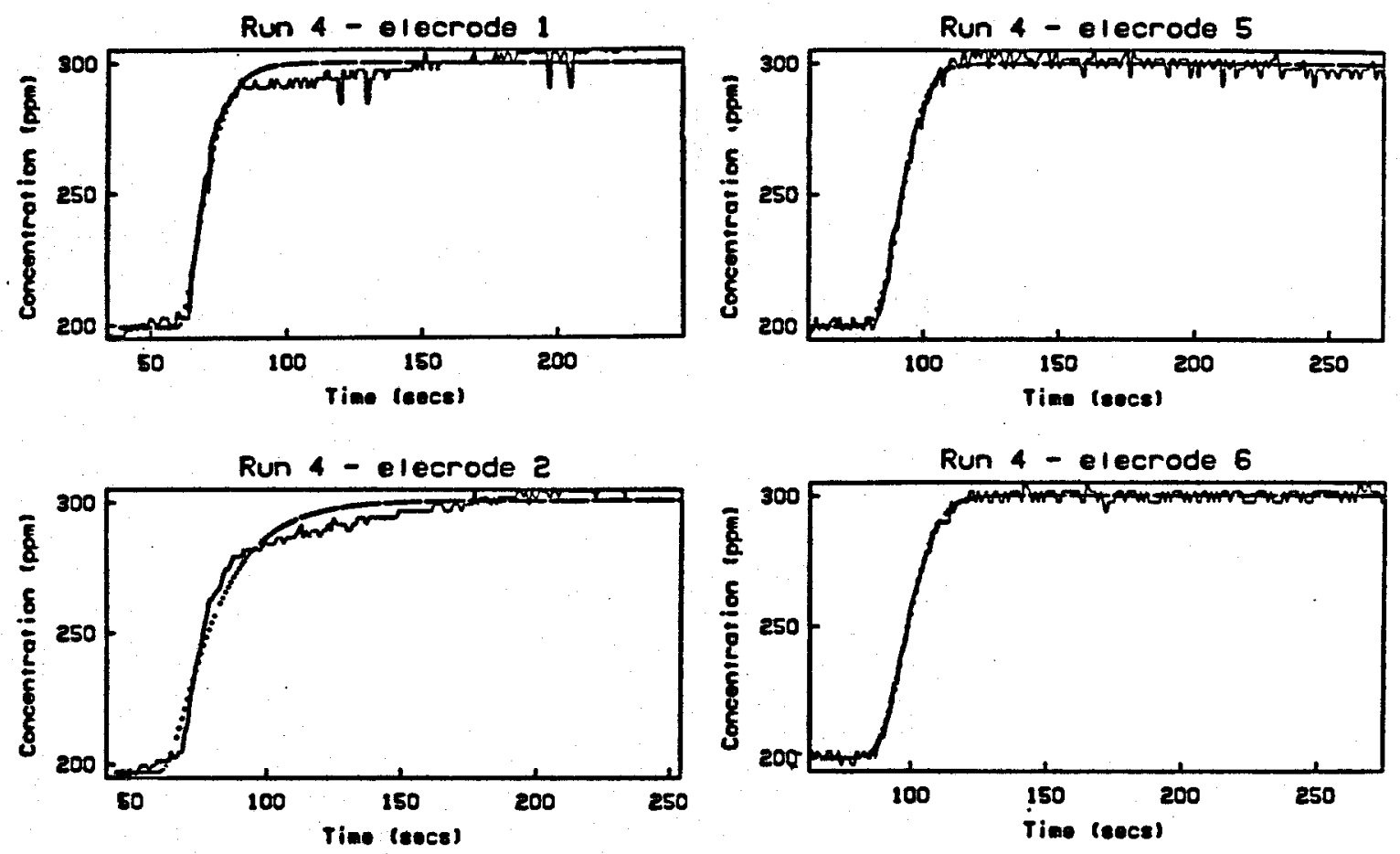

Run 4 - el ecrode 3
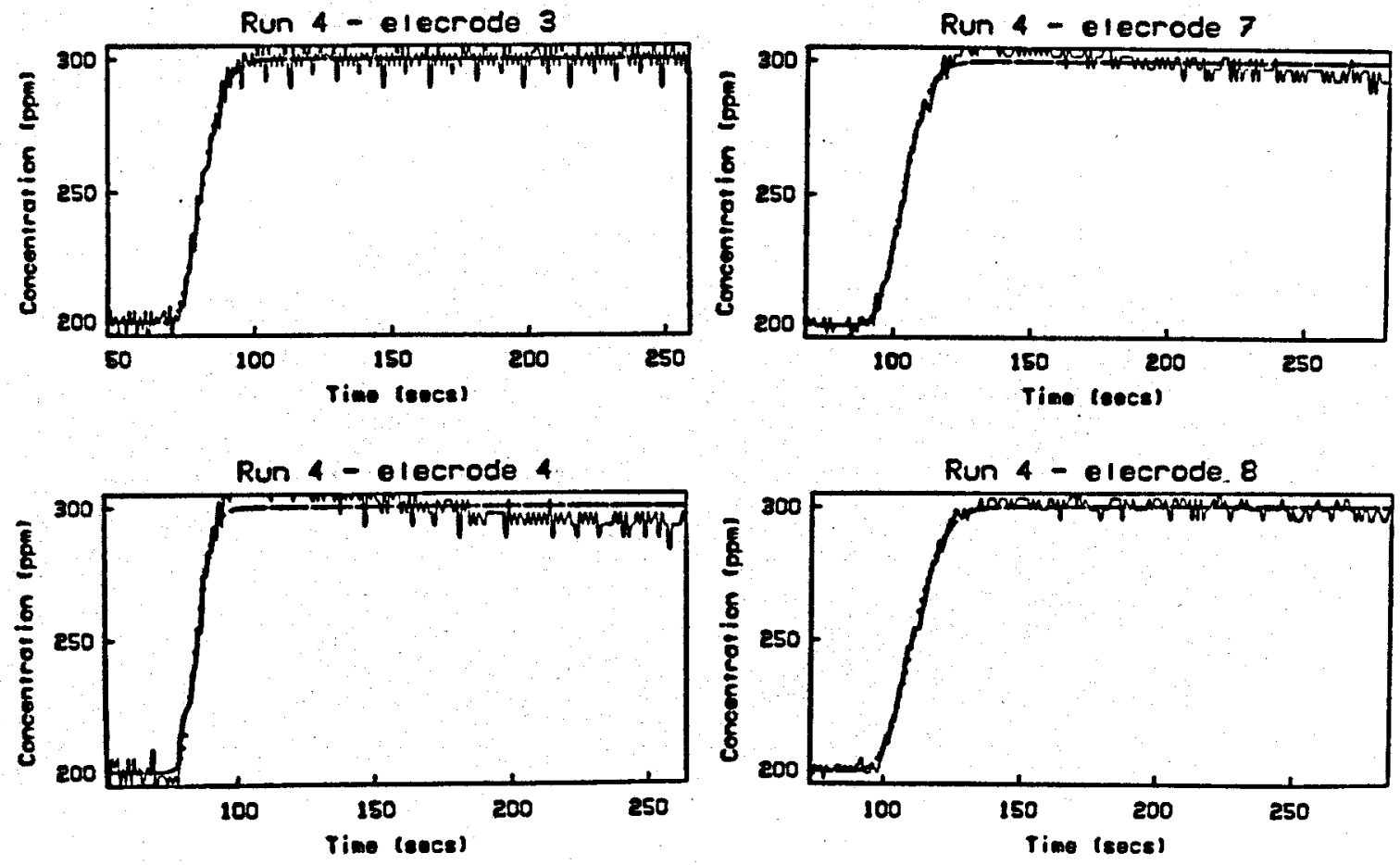

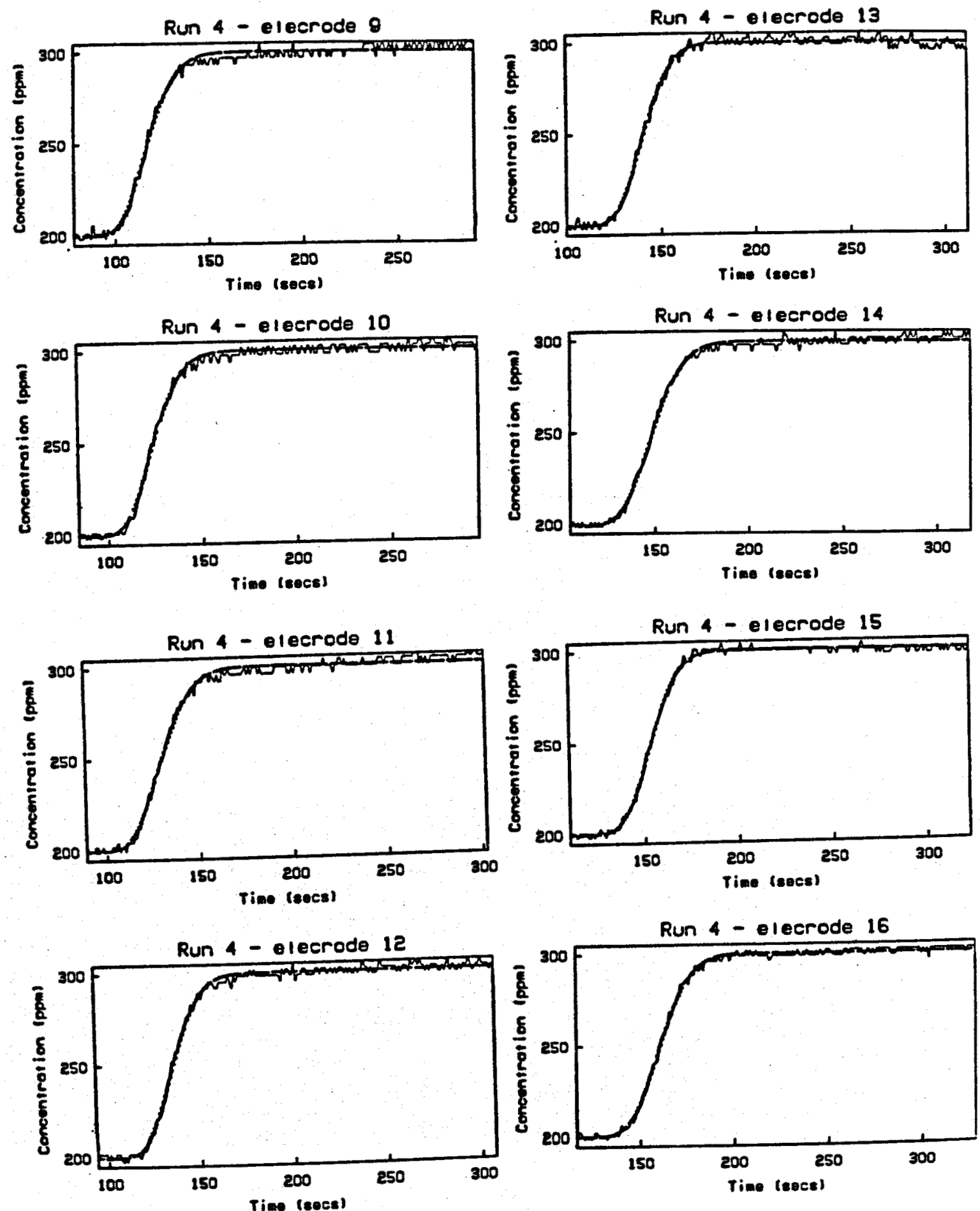

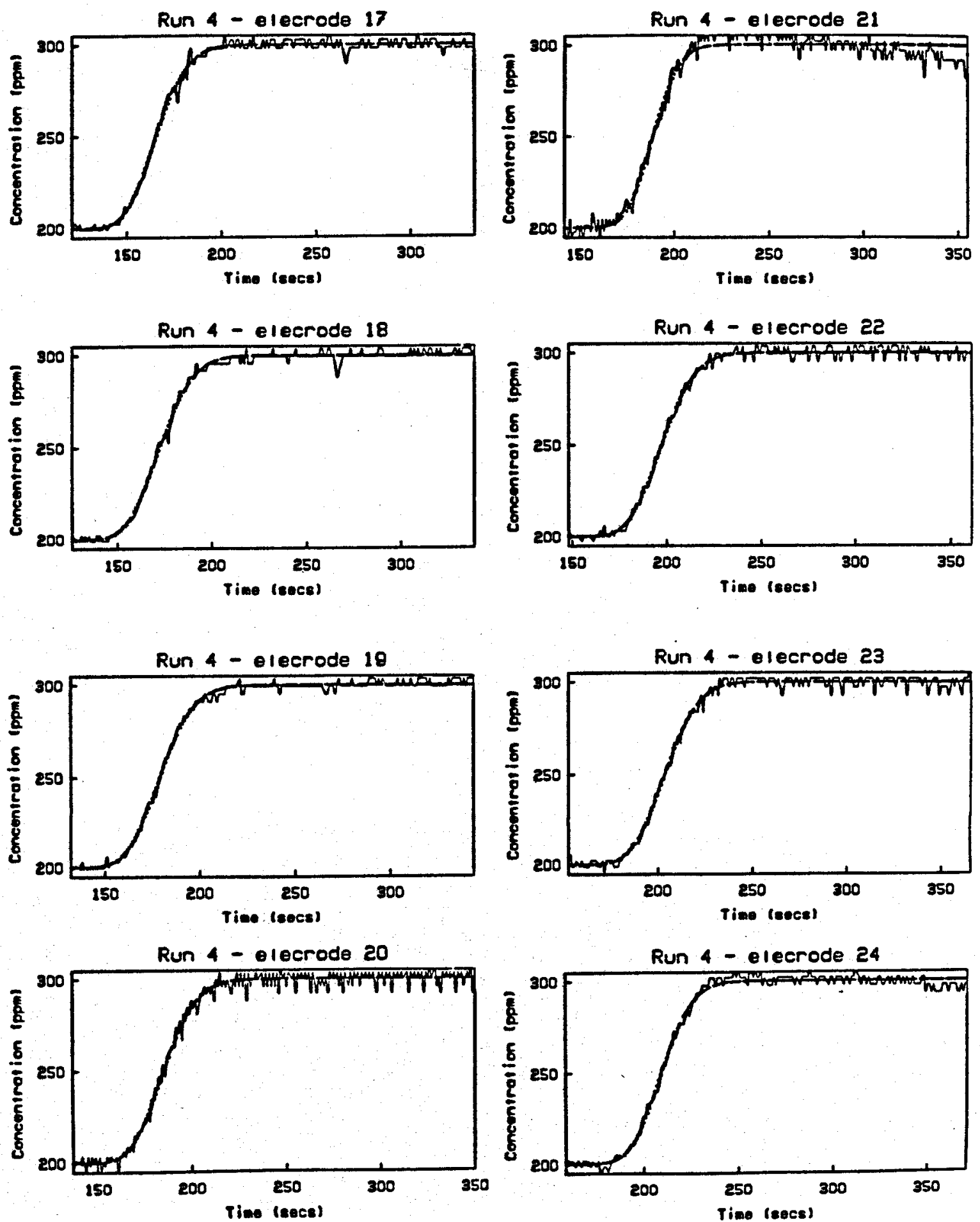

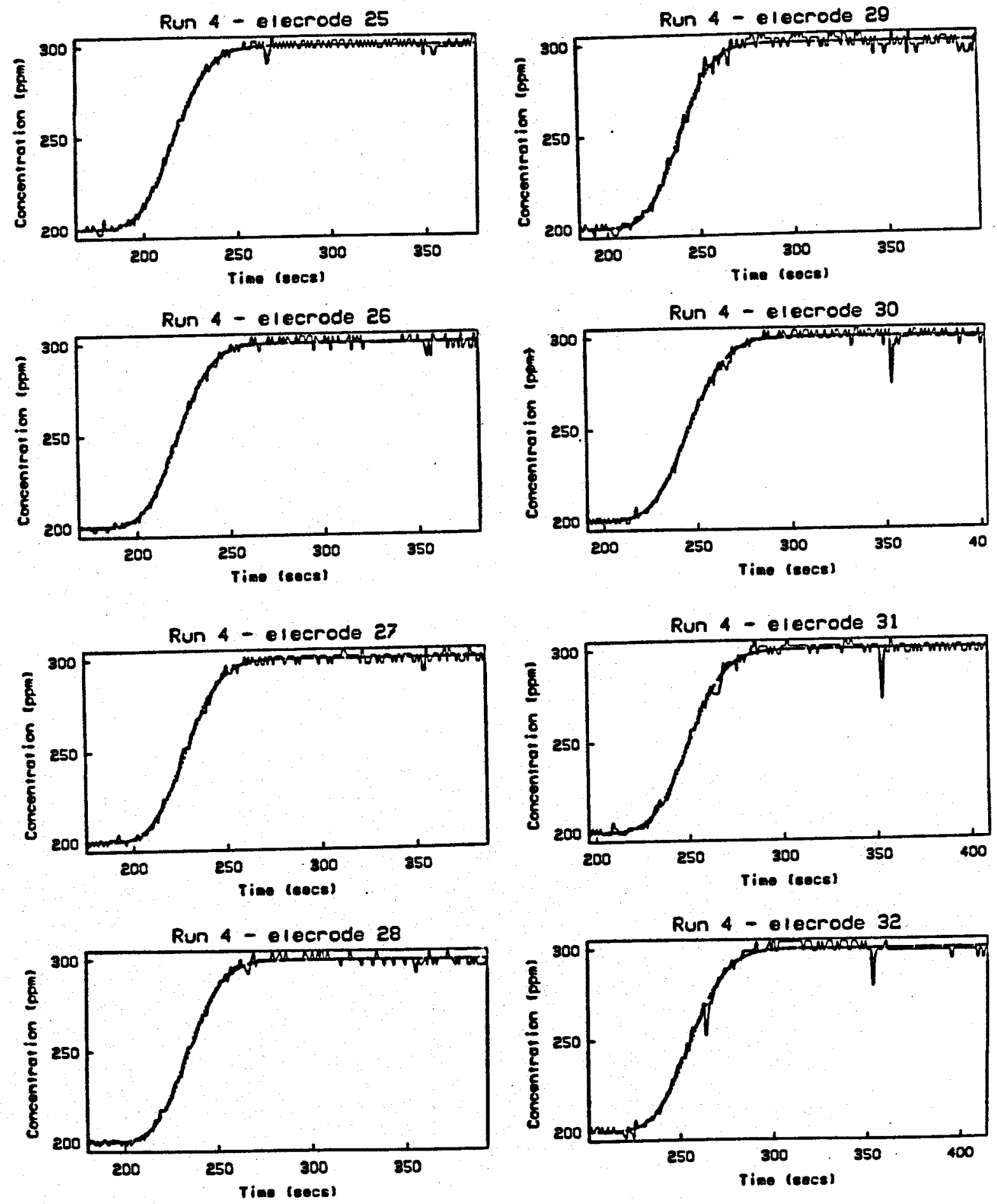


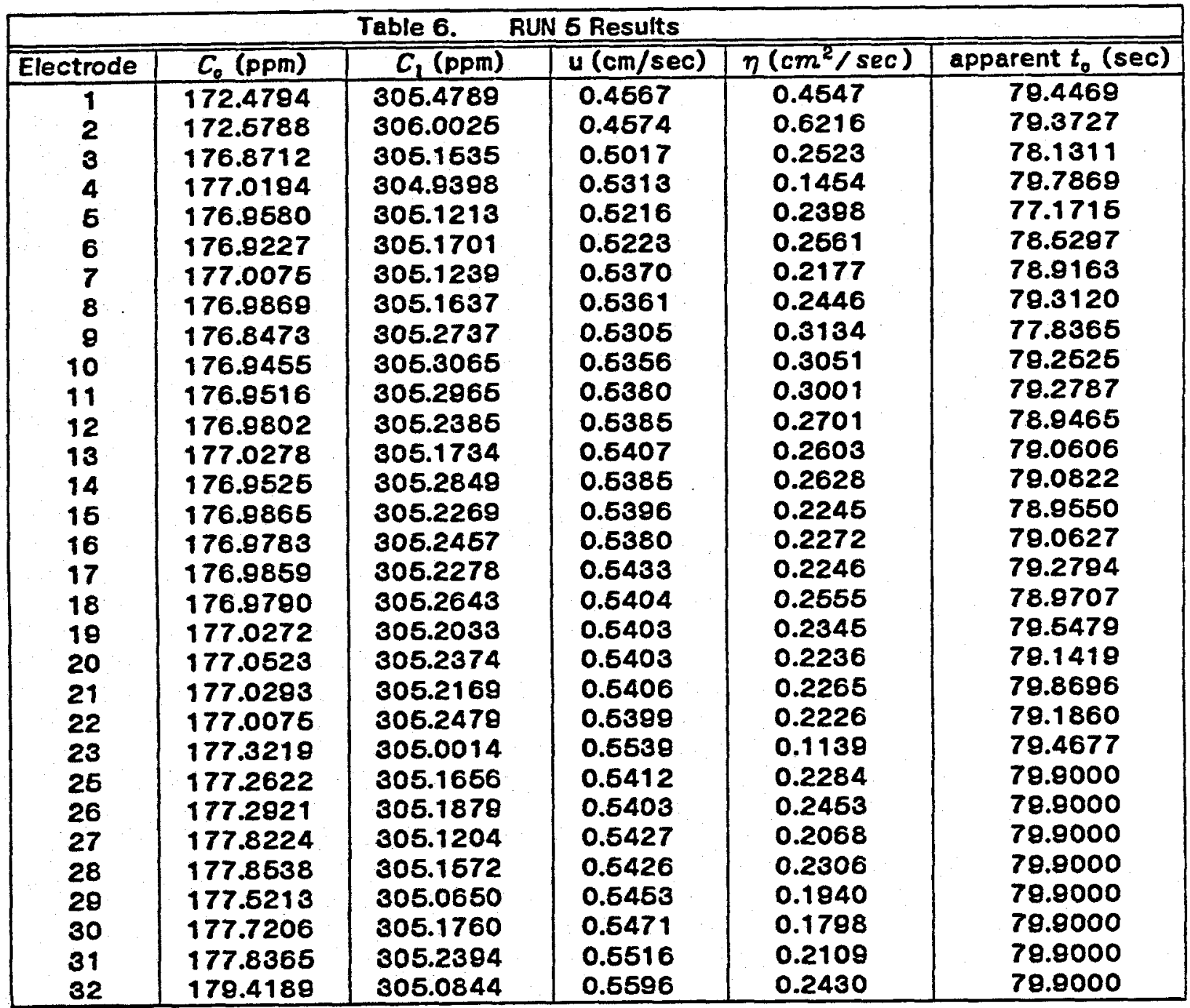

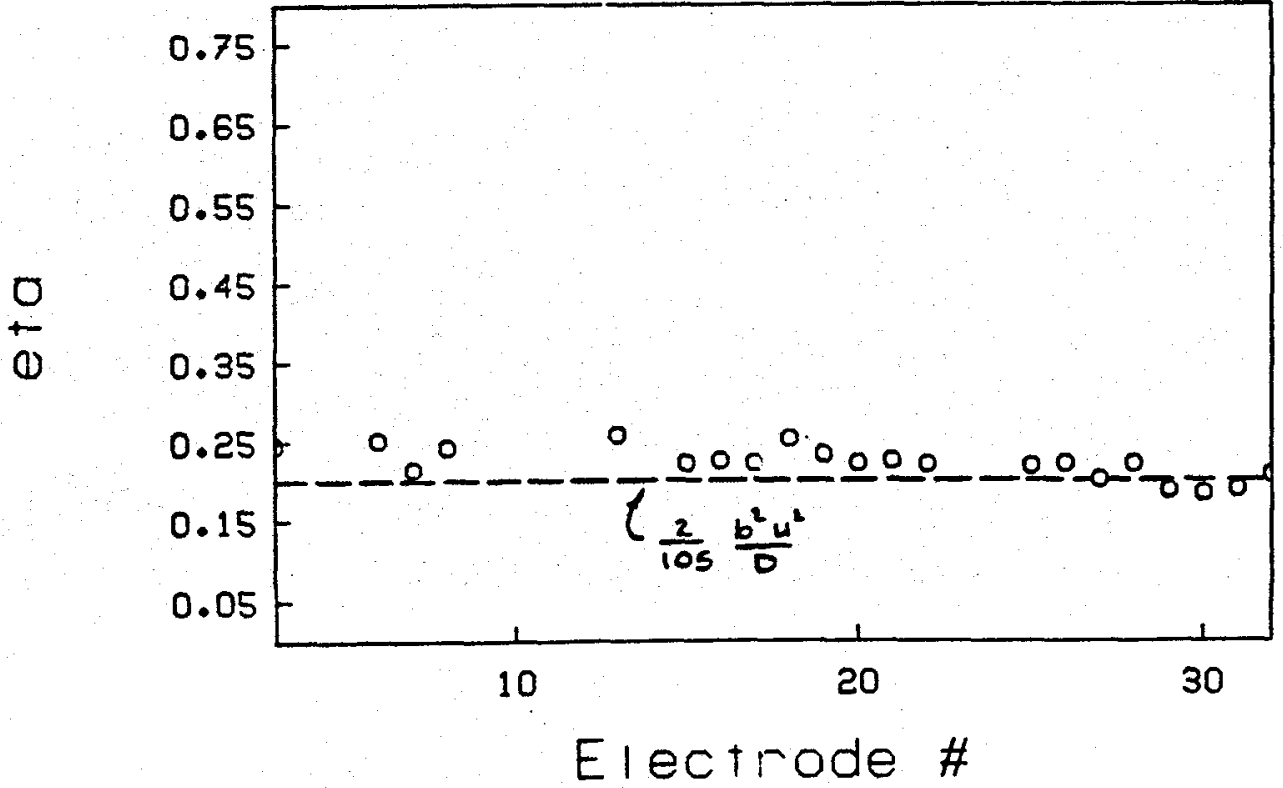

Fig. 10. Comparison of estimated and calculated dispersivity. Run 5. 

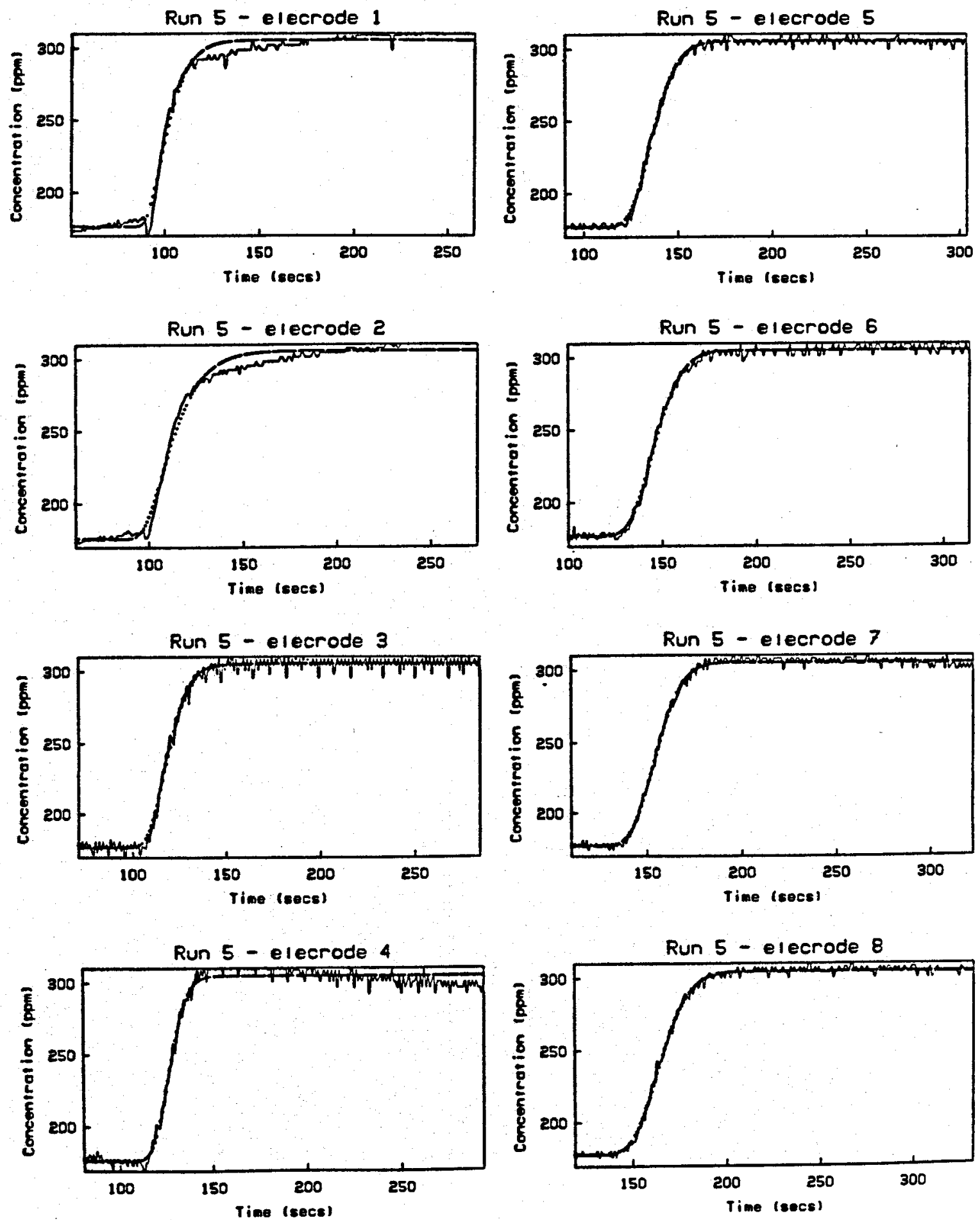

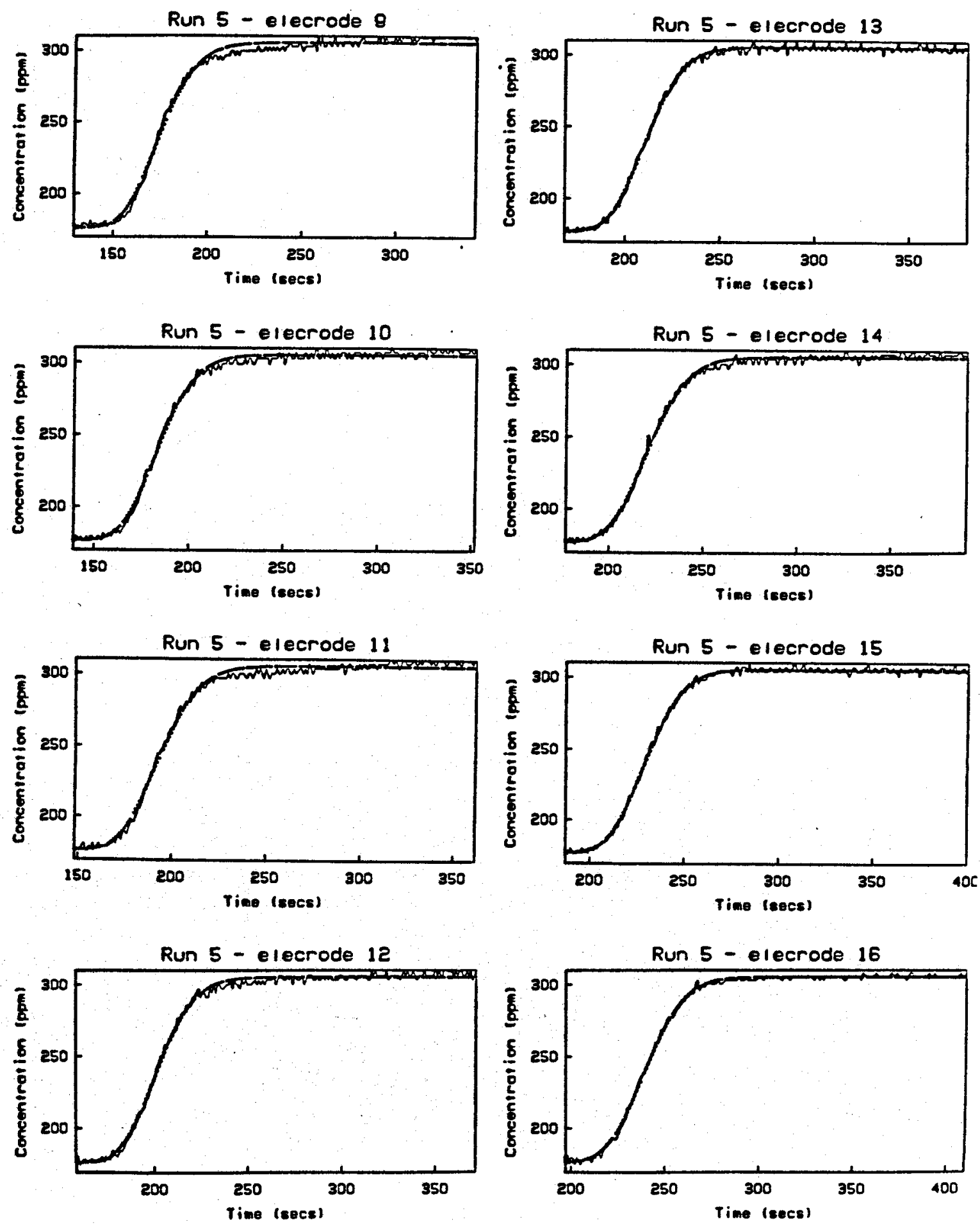

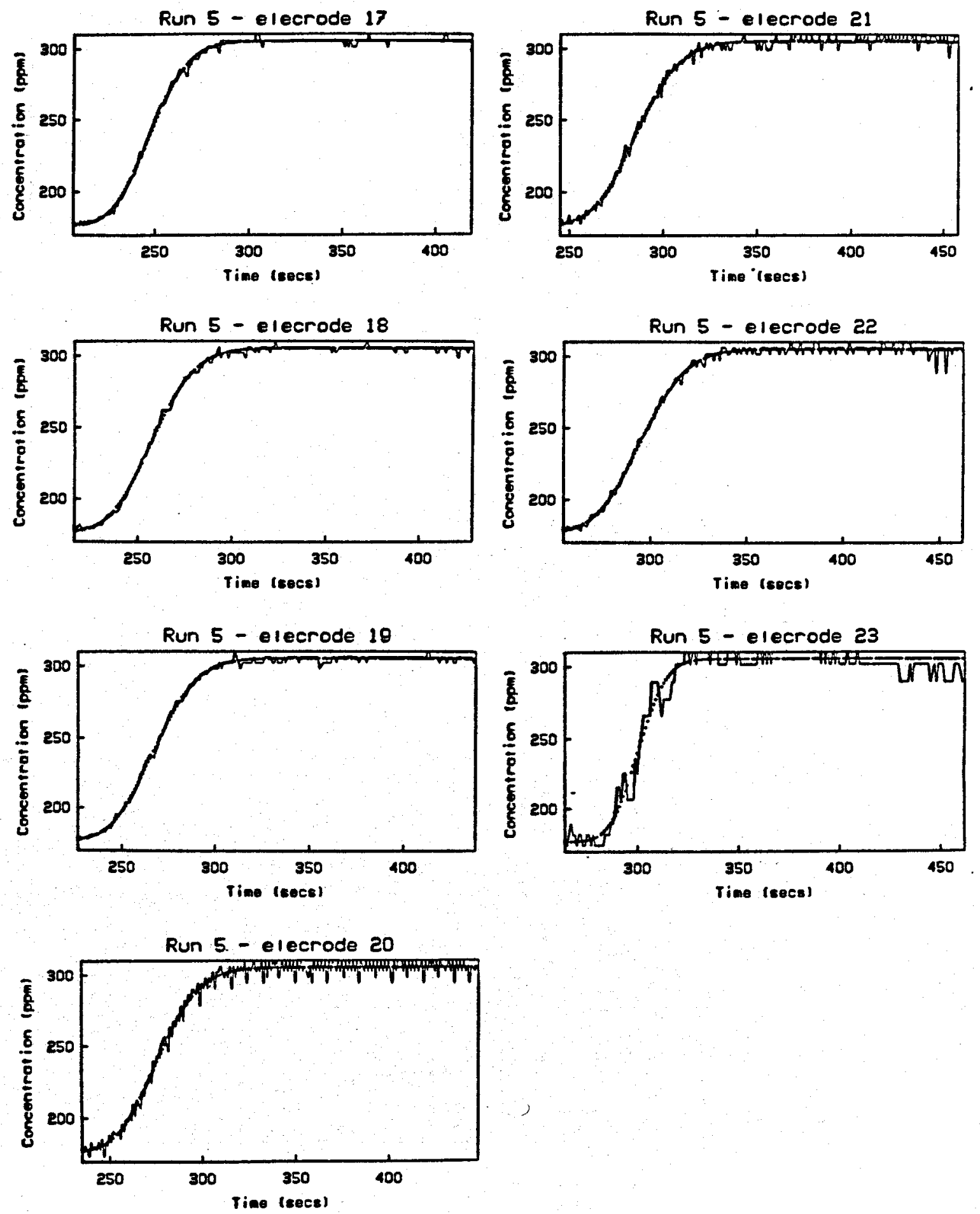

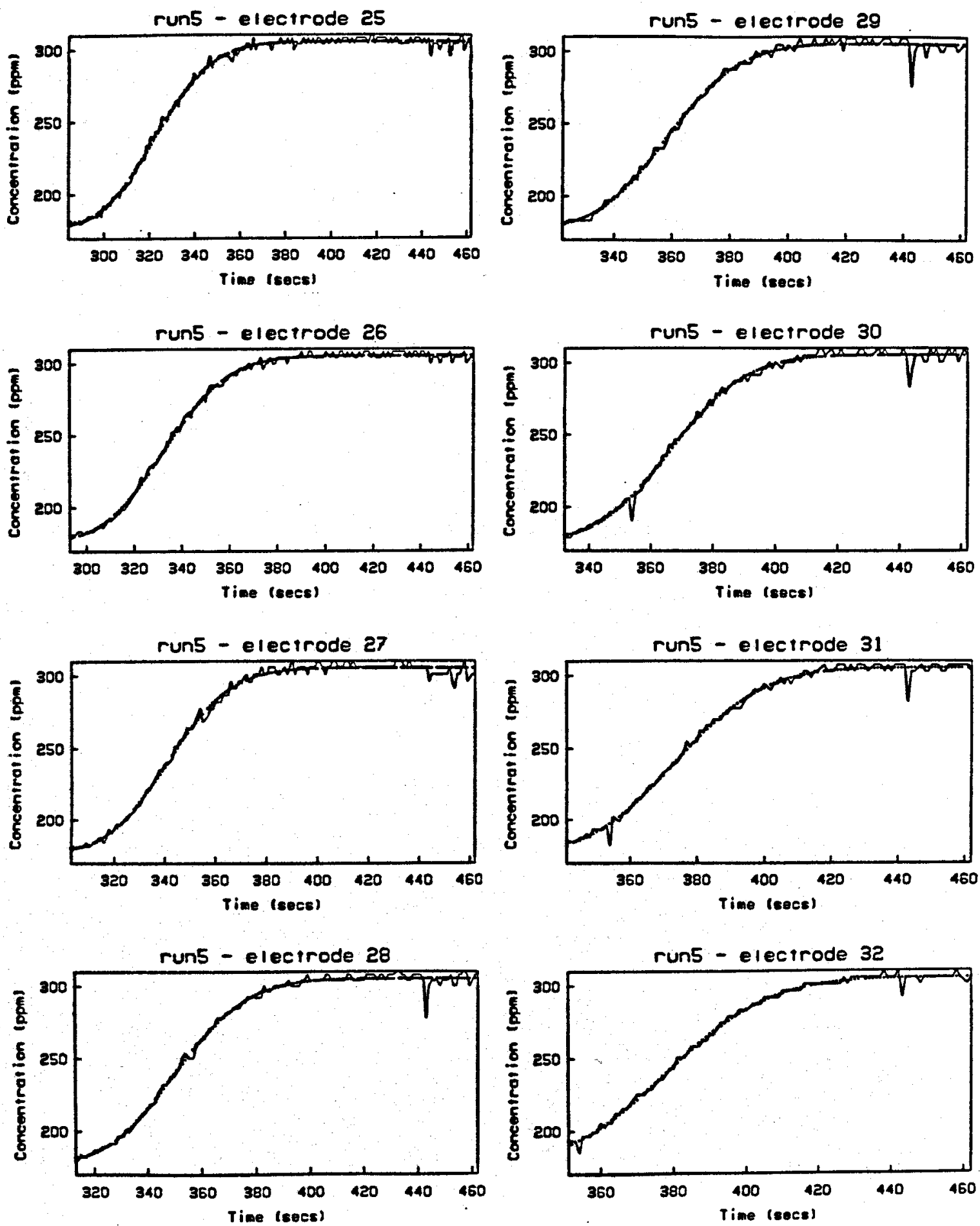


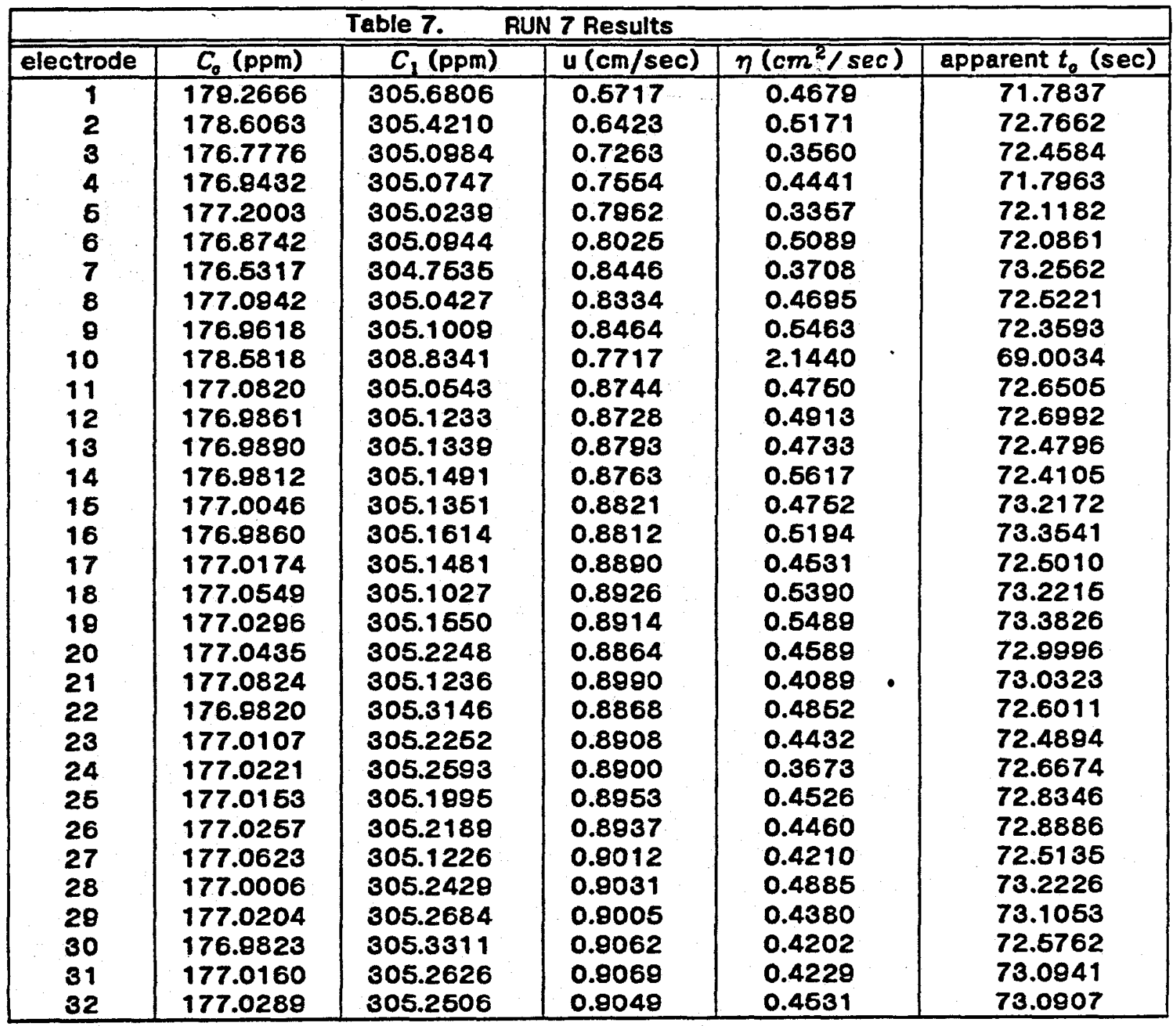

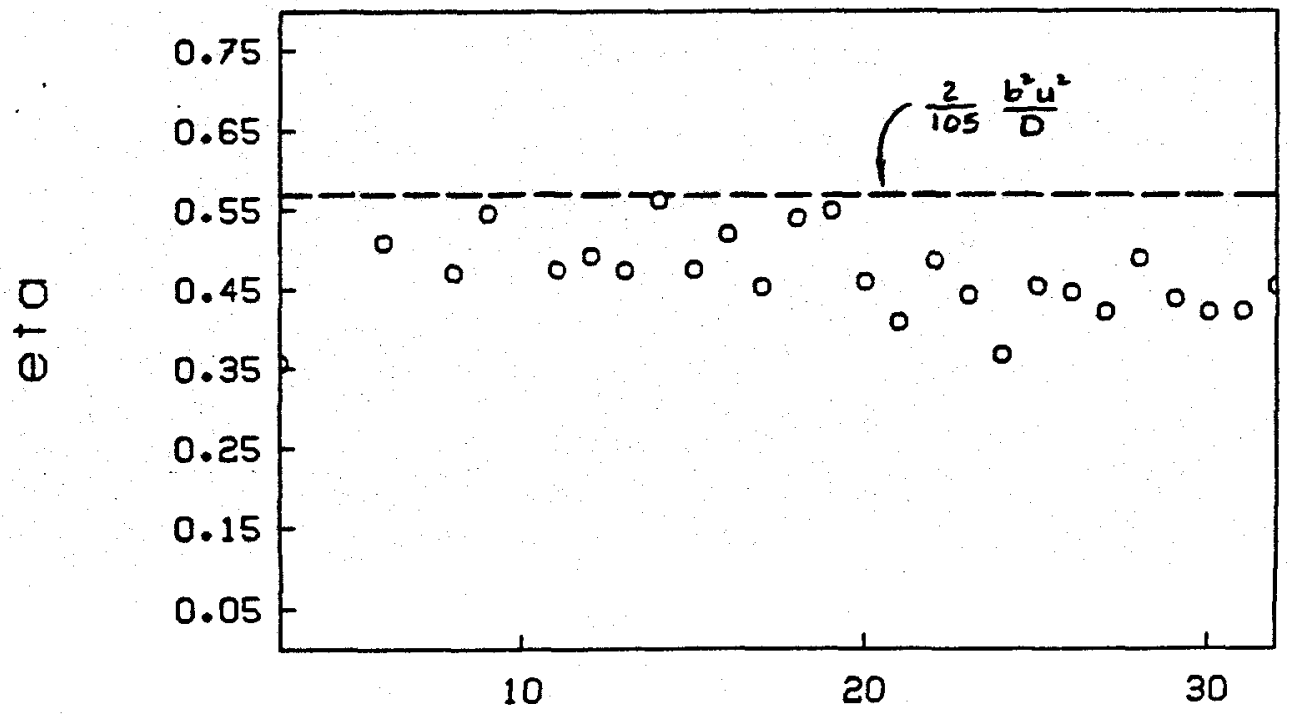

Electrode \#

Fig. 11. Comparison of estimated and calculated dispersivity. Run 7. 

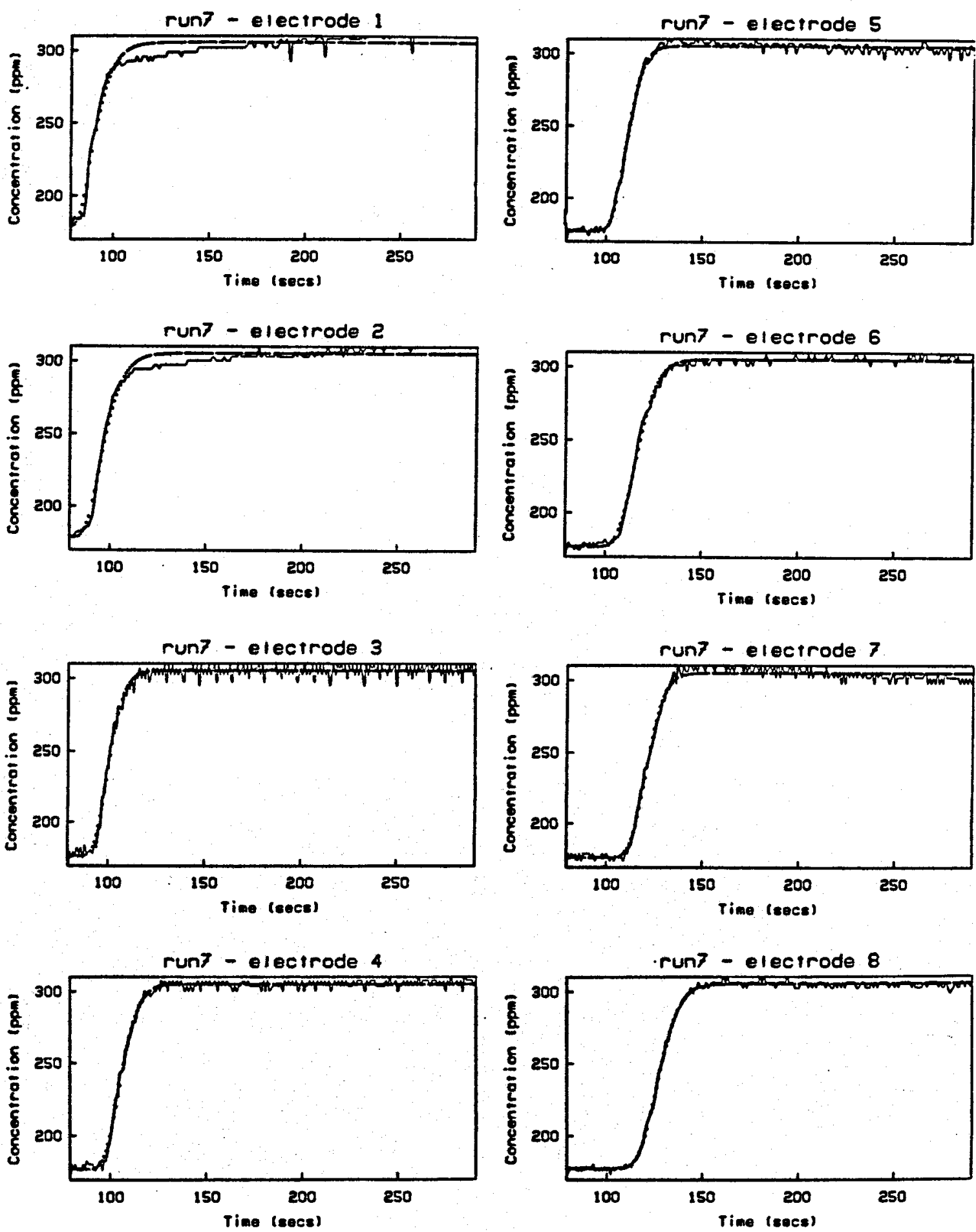

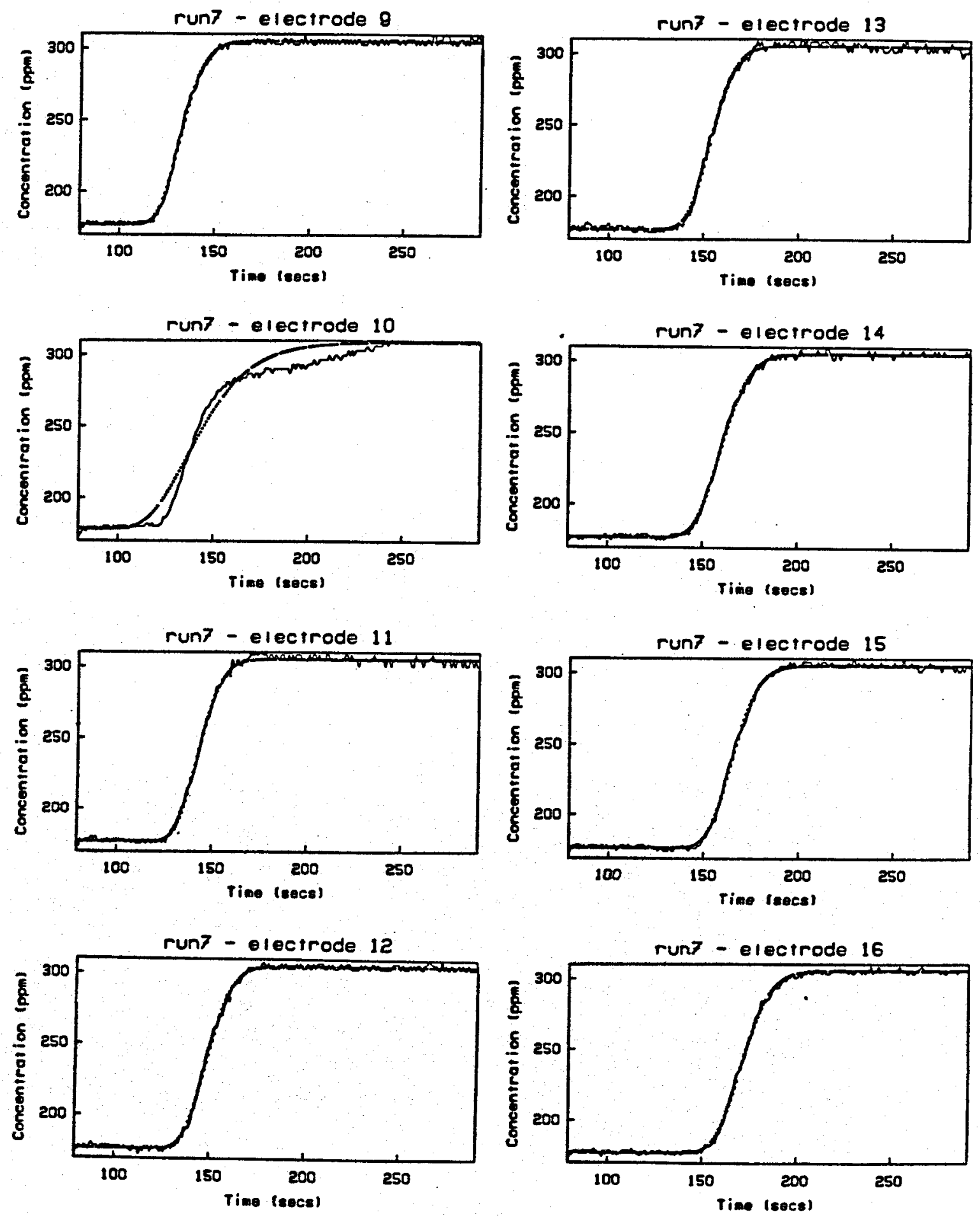

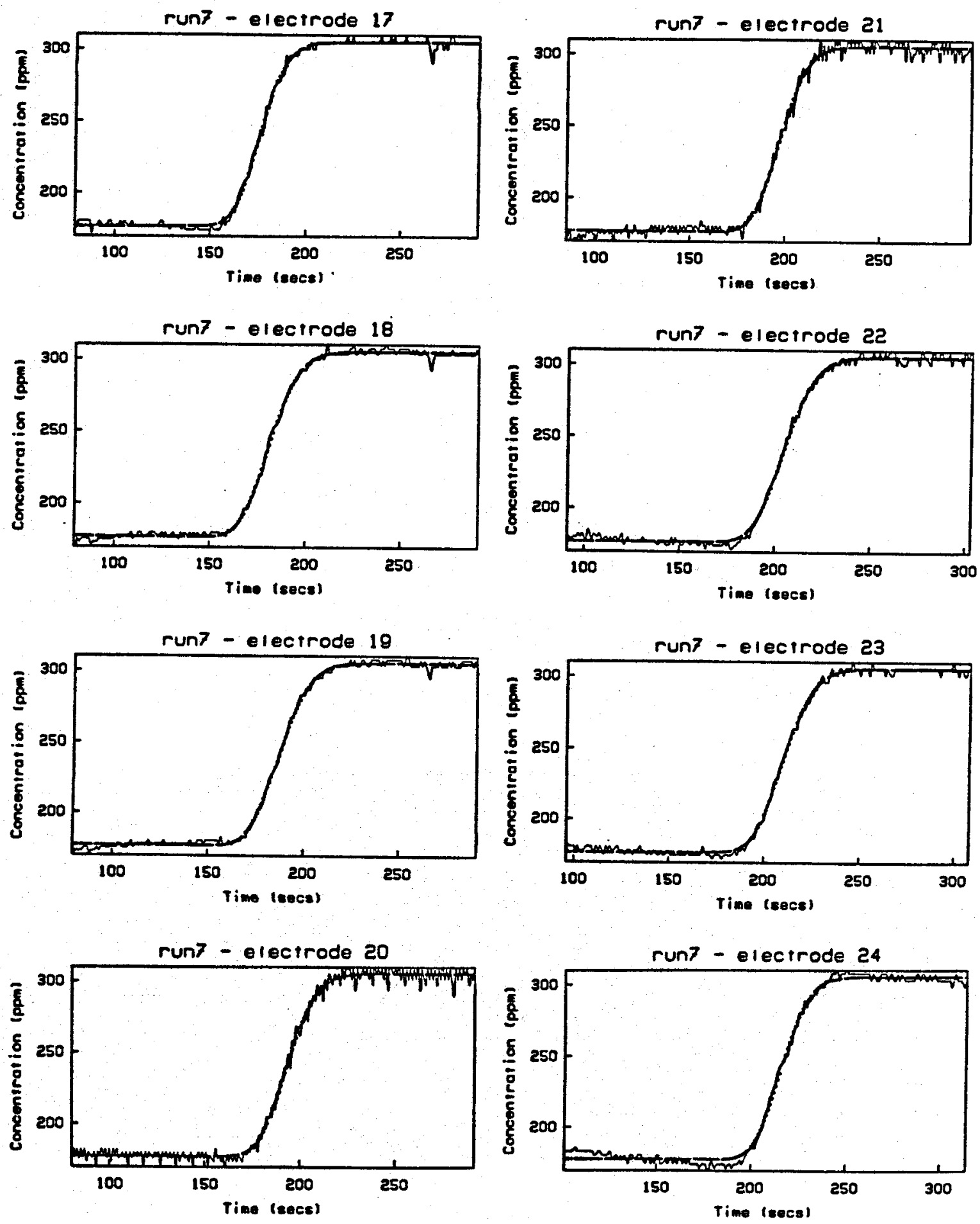

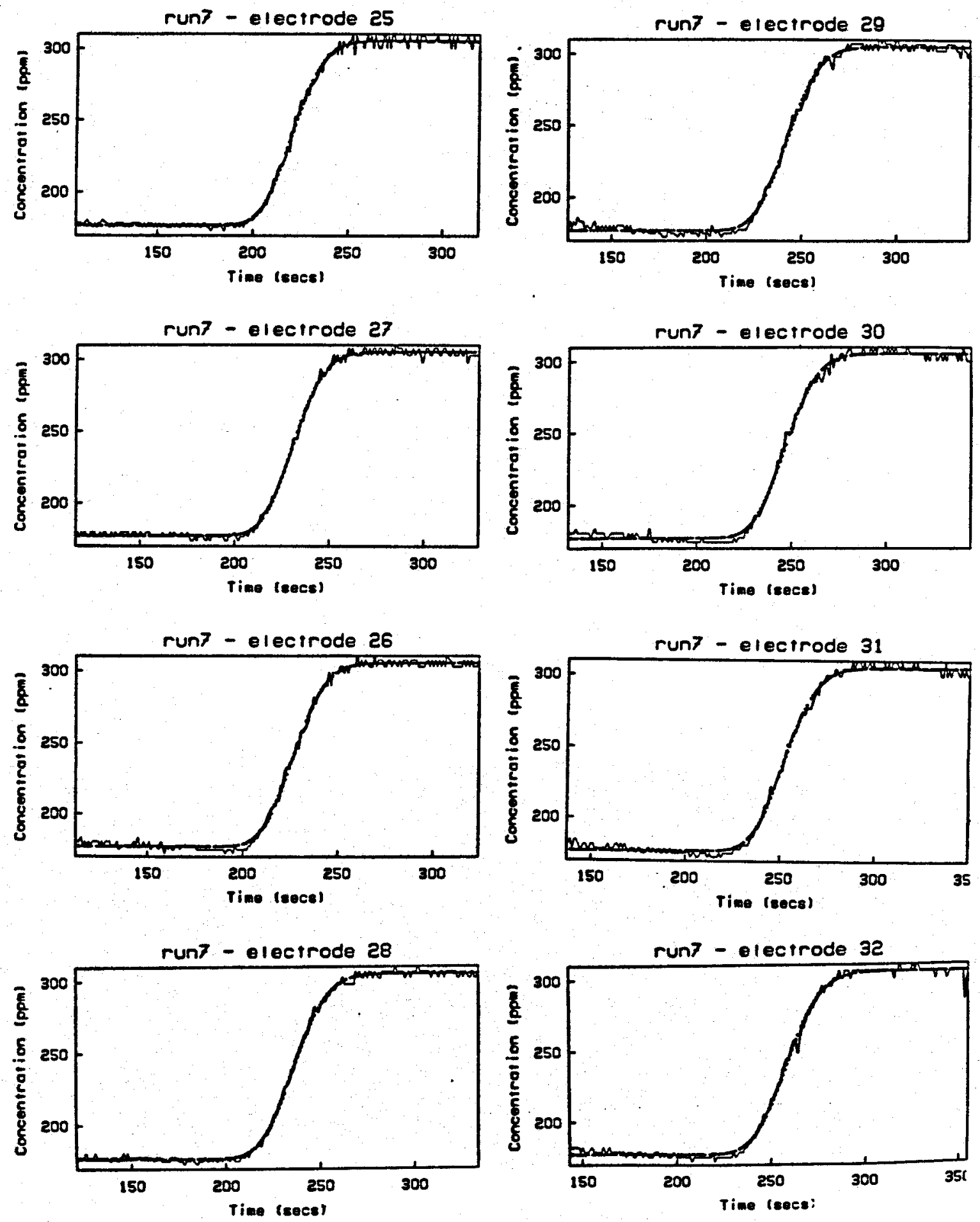
Table 8. RUN 8 Results

\begin{tabular}{|c|c|c|c|c|c|}
\hline \multicolumn{6}{|c|}{ Table 8. RUN 8 Results } \\
\hline Electrode & $\overline{C_{0}(\mathrm{ppm})}$ & $\overline{C_{1}(\mathrm{ppm})}$ & $u(\mathrm{~cm} / \mathrm{sec})$ & $\eta\left(\mathrm{cm}^{2} / \mathrm{sec}\right)$ & apparent $t_{0}$ (sec) \\
\hline $\begin{array}{l}2 \\
3 \\
4 \\
5 \\
6 \\
7 \\
8 \\
9 \\
10 \\
11 \\
12 \\
13 \\
14 \\
16 \\
16 \\
17 \\
18 \\
18 \\
20 \\
21 \\
22 \\
23 \\
24 \\
26 \\
26 \\
27 \\
28 \\
29 \\
30 \\
31 \\
32\end{array}$ & $\begin{array}{l}170.1389 \\
179.8520 \\
176.8666 \\
176.7606 \\
176.9526 \\
176.9783 \\
176.8639 \\
176.8430 \\
176.8034 \\
176.8416 \\
176.9483 \\
176.9379 \\
176.8700 \\
176.9528 \\
176.9221 \\
177.1410 \\
176.9500 \\
176.9141 \\
176.9196 \\
177.0144 \\
176.8655 \\
176.9429 \\
176.9425 \\
176.9841 \\
176.9982 \\
176.9812 \\
177.0265 \\
176.9814 \\
177.0031 \\
176.9886 \\
176.9780\end{array}$ & $\begin{array}{l}304.8965 \\
306.0940 \\
305.3446 \\
305.5164 \\
306.1938 \\
305.4040 \\
305.6481 \\
305.6109 \\
305.7105 \\
305.6765 \\
305.3648 \\
305.4082 \\
305.4972 \\
305.3391 \\
305.3843 \\
305.1577 \\
305.3545 \\
305.4277 \\
305.6346 \\
305.3112 \\
305.6125 \\
305.4110 \\
305.4284 \\
305.4207 \\
305.4667 \\
305.6110 \\
305.6131 \\
306.3142 \\
306.6916 \\
308.1860 \\
310.6608\end{array}$ & $\begin{array}{l}0.5513 \\
0.4889 \\
0.4808 \\
0.4685 \\
0.4655 \\
0.4734 \\
0.4668 \\
0.4658 \\
0.4613 \\
0.4622 \\
0.4629 \\
0.4610 \\
0.4588 \\
0.4695 \\
0.4569 \\
0.4646 \\
0.4557 \\
0.4545 \\
0.4527 \\
0.4628 \\
0.4489 \\
0.4499 \\
0.4502 \\
0.4494 \\
0.4490 \\
0.4498 \\
0.4507 \\
0.4496 \\
0.4511 \\
0.4516 \\
0.4541\end{array}$ & $\begin{array}{l}0.9233 \\
0.4890 \\
0.2899 \\
0.2779 \\
0.2636 \\
0.1685 \\
0.2108 \\
0.2067 \\
0.2355 \\
0.2043 \\
0.1351 \\
0.1314 \\
0.1966 \\
0.1341 \\
0.1555 \\
0.2326 \\
0.1753 \\
0.1594 \\
0.1775 \\
0.1384 \\
0.1951 \\
0.1390 \\
0.1712 \\
0.1376 \\
0.1397 \\
0.1285 \\
0.1225 \\
0.1238 \\
0.1401 \\
0.1342 \\
0.1365\end{array}$ & 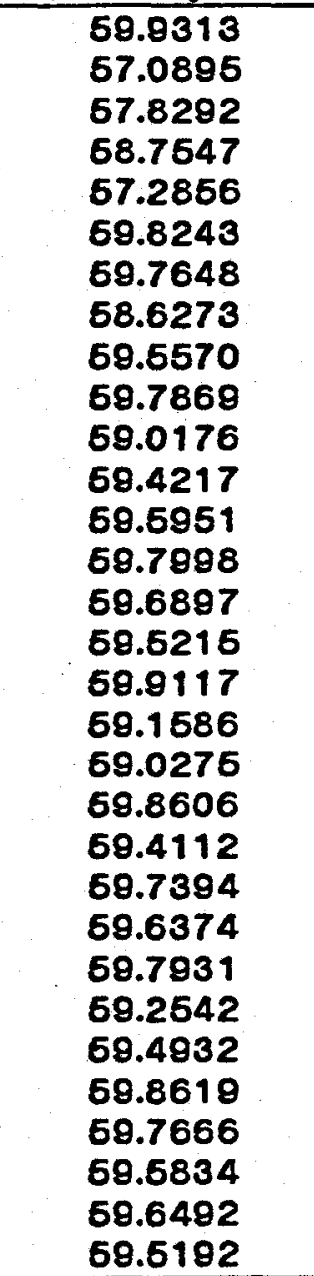 \\
\hline
\end{tabular}

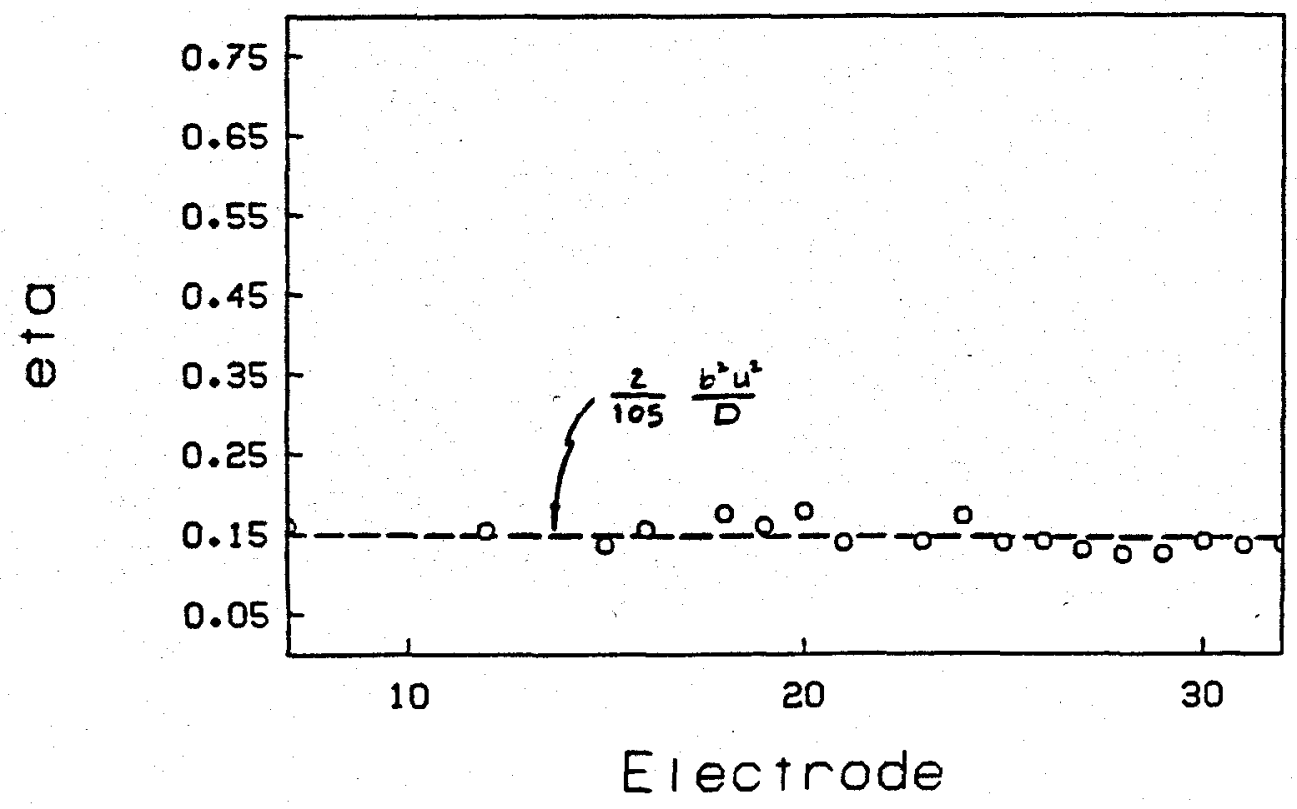

Fig. 12. Comparison of estimated and calculated dispersivity. Run 8. 

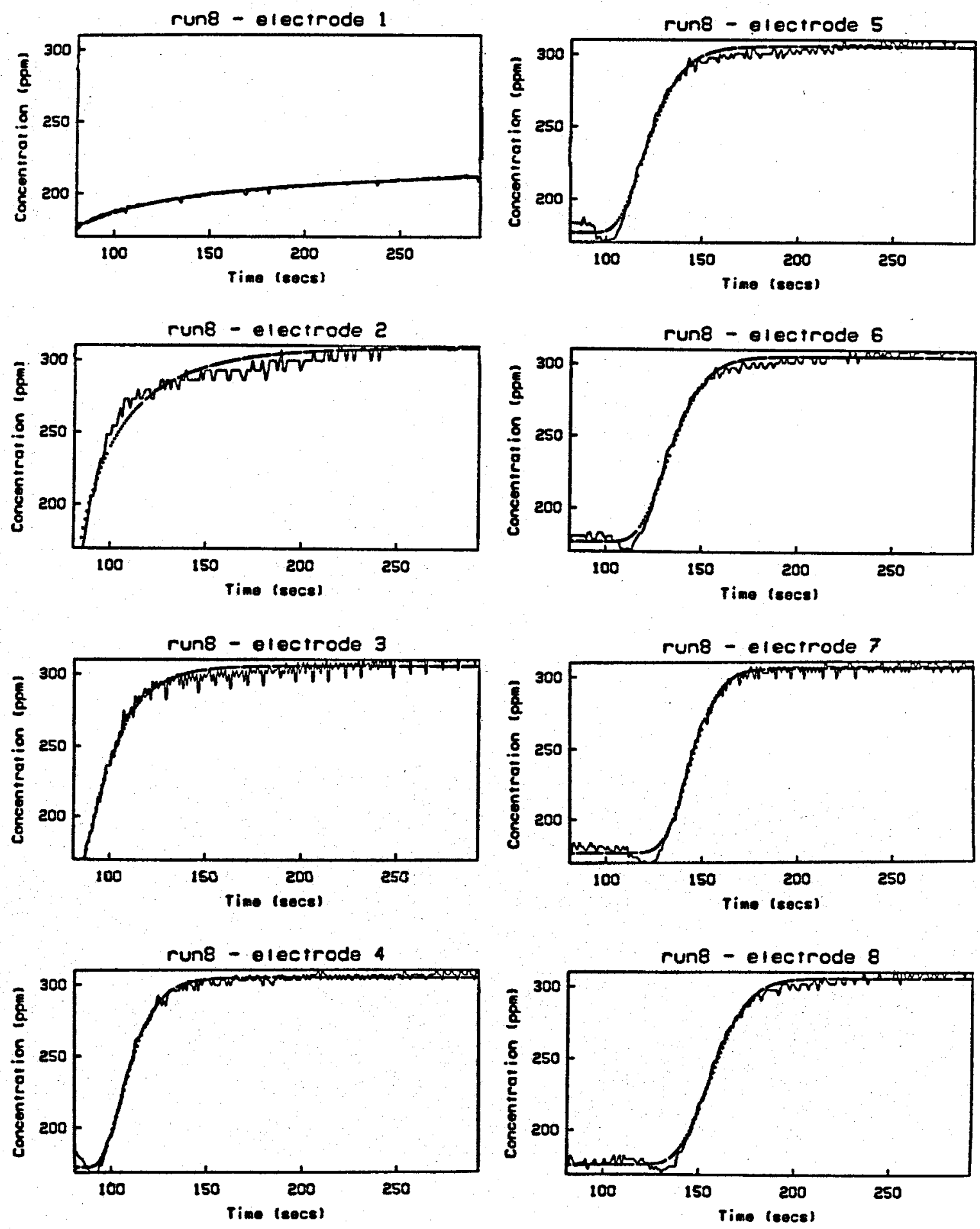

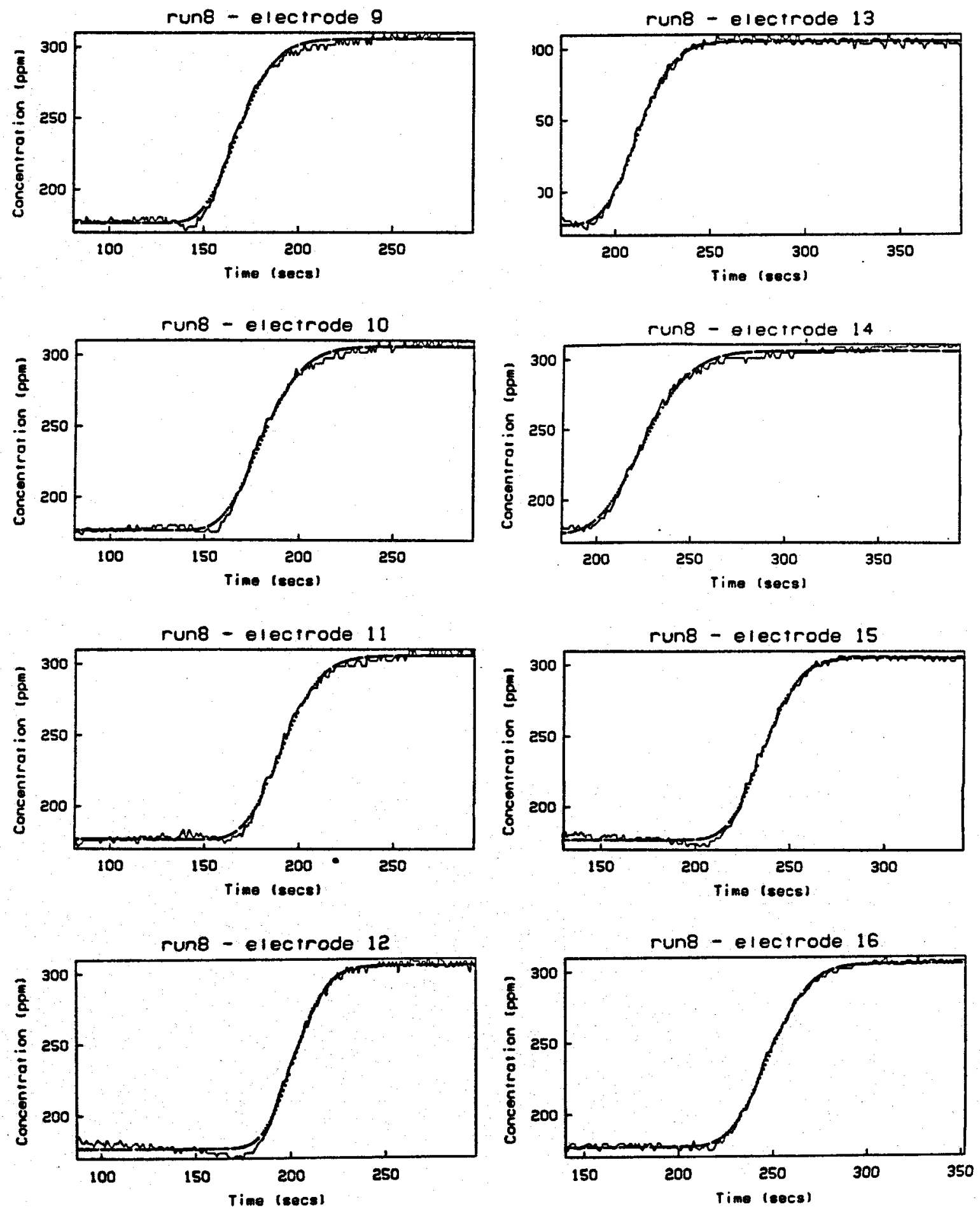

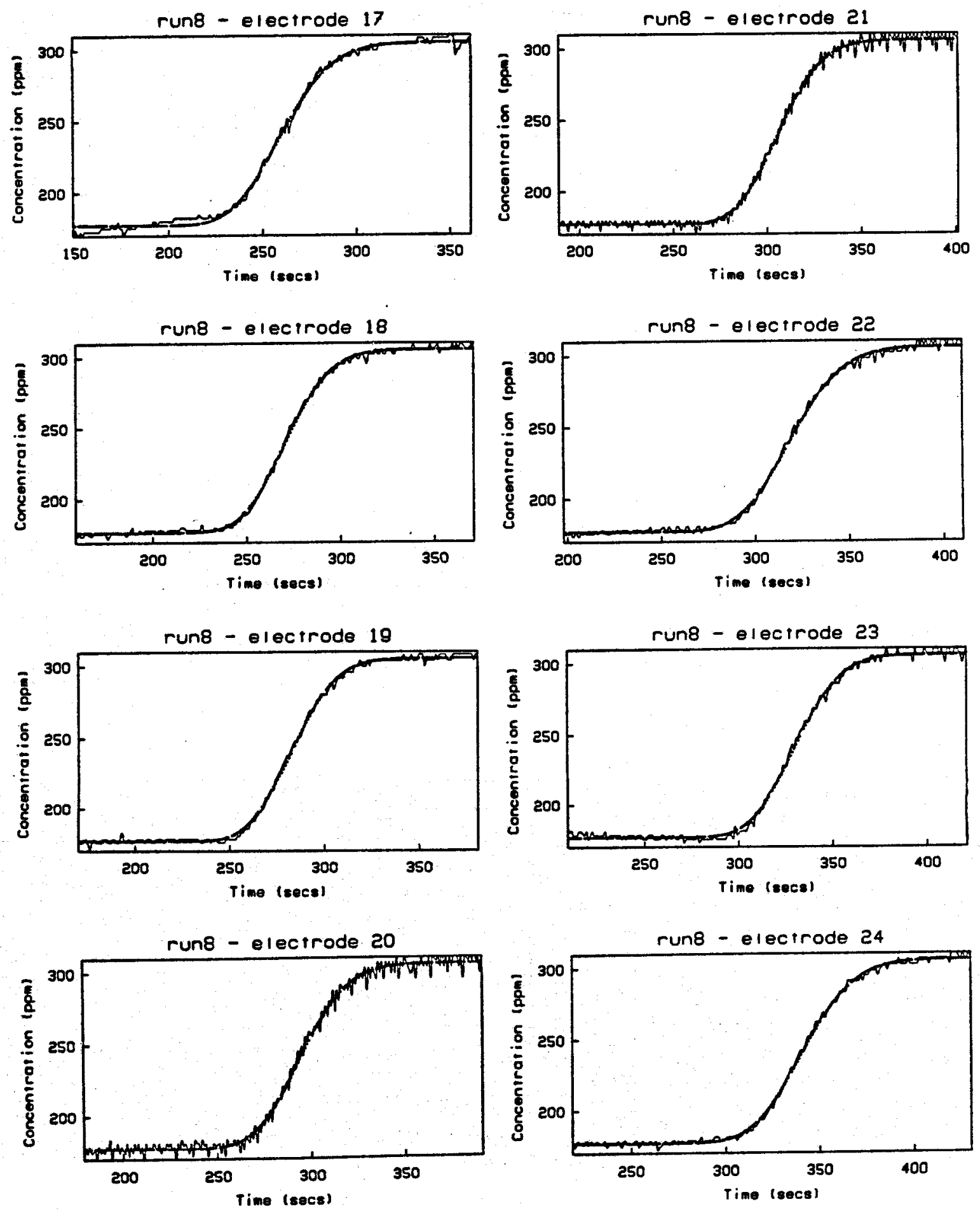

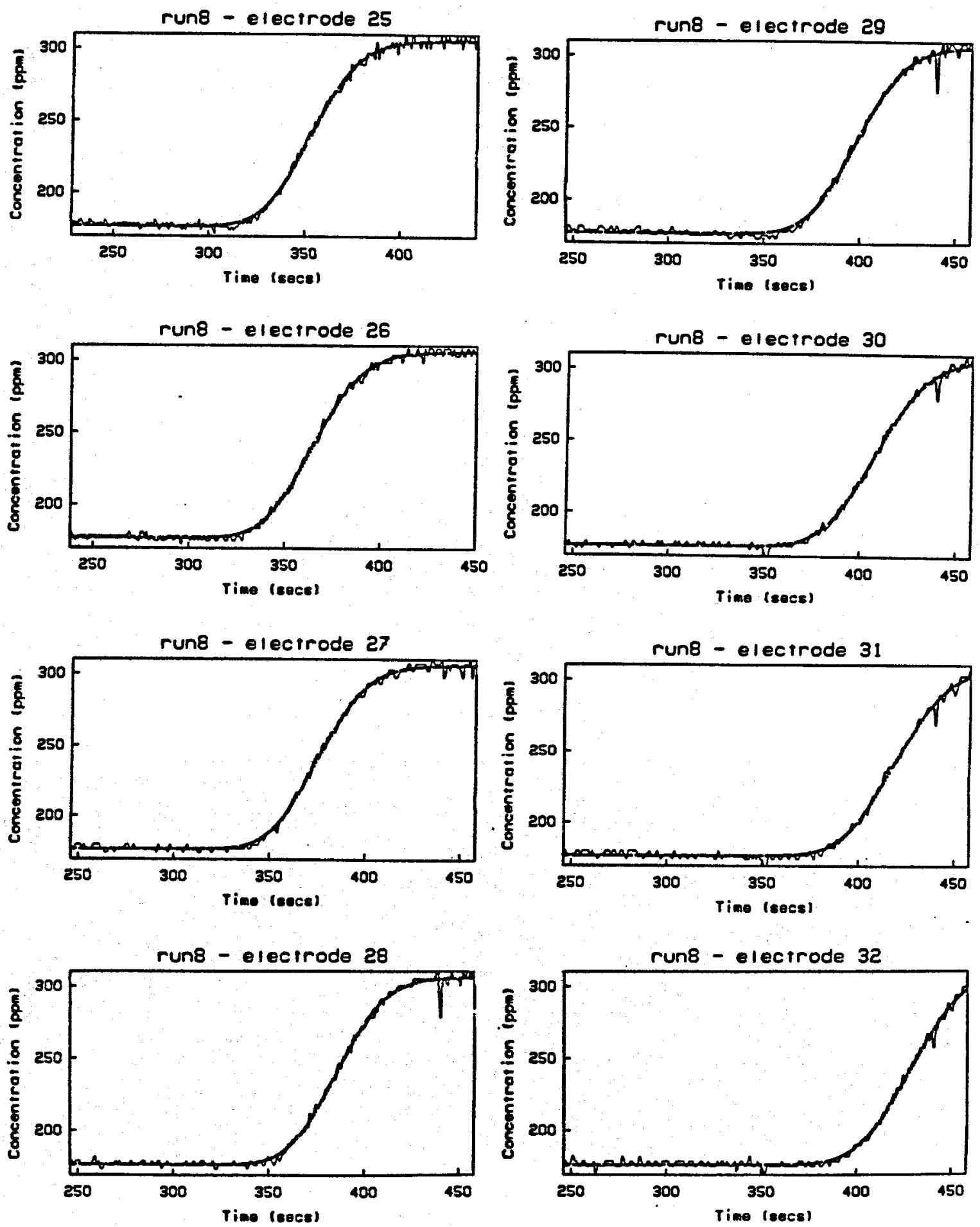


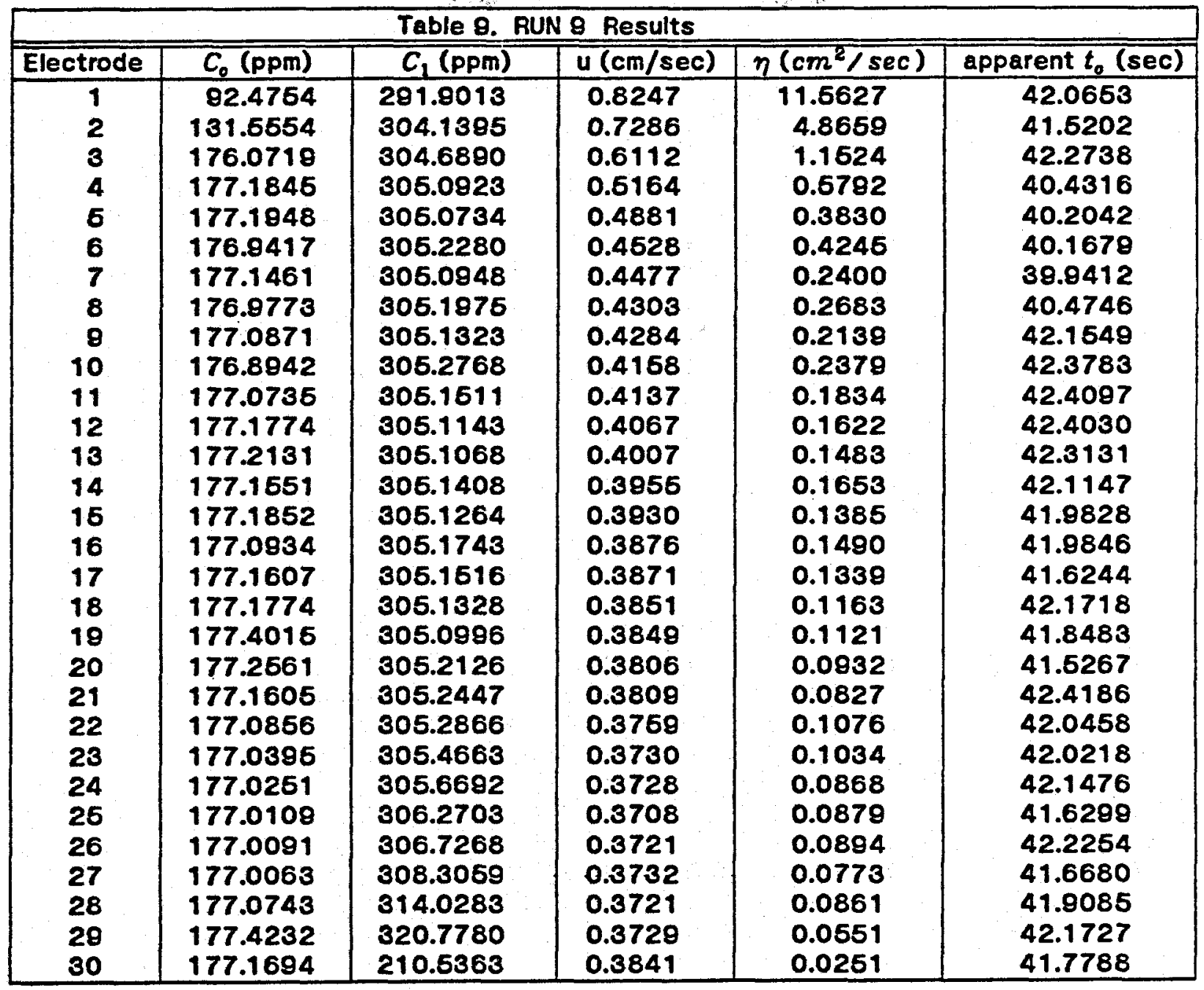

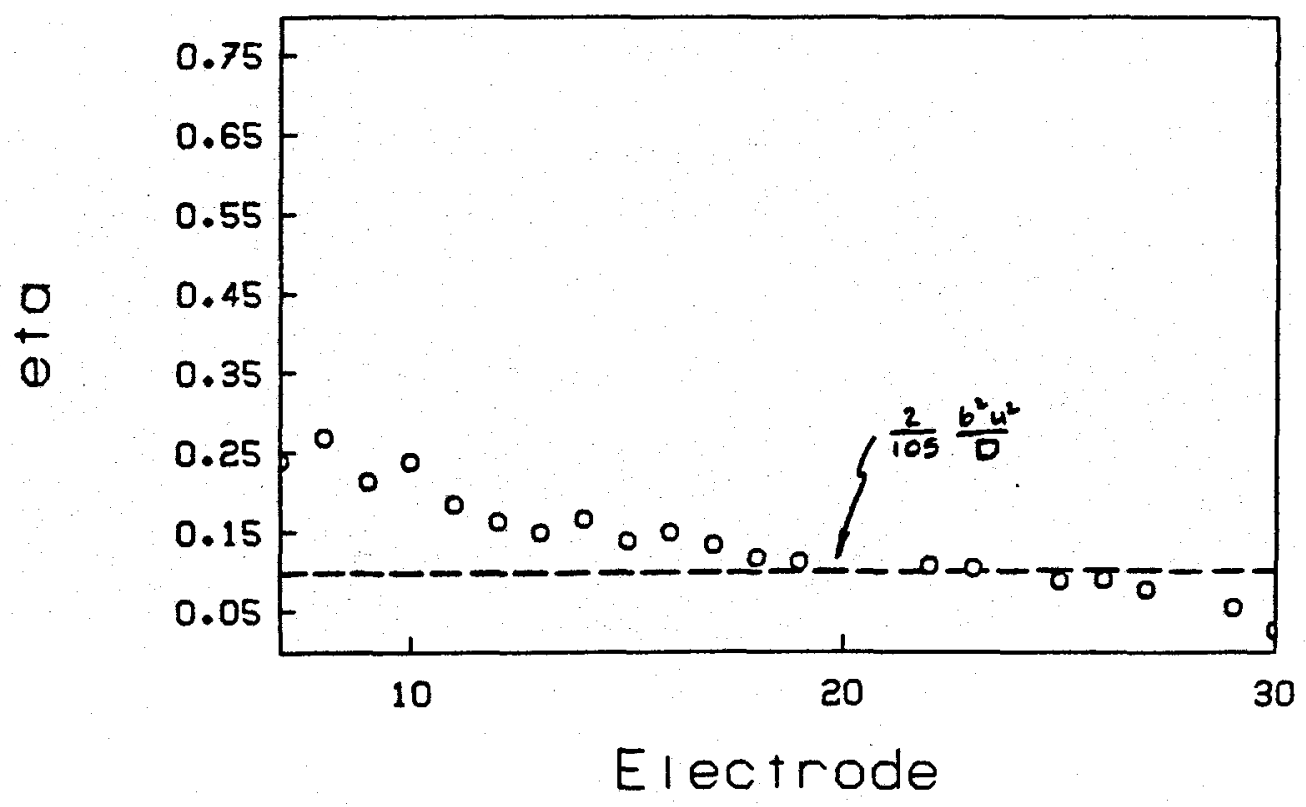

Fig. 13. Comparison of estimated and calculated dispersivity. Run 9. 

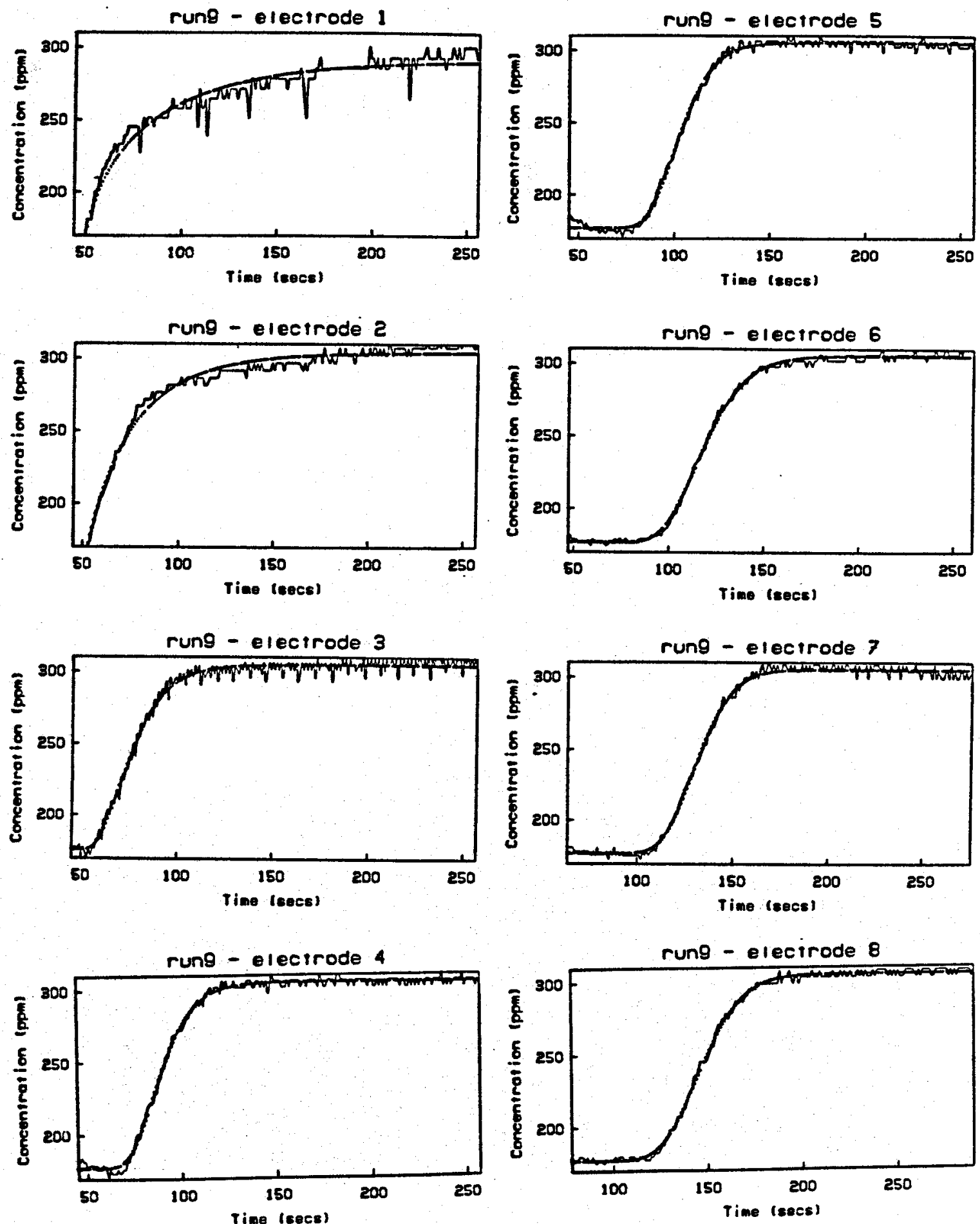

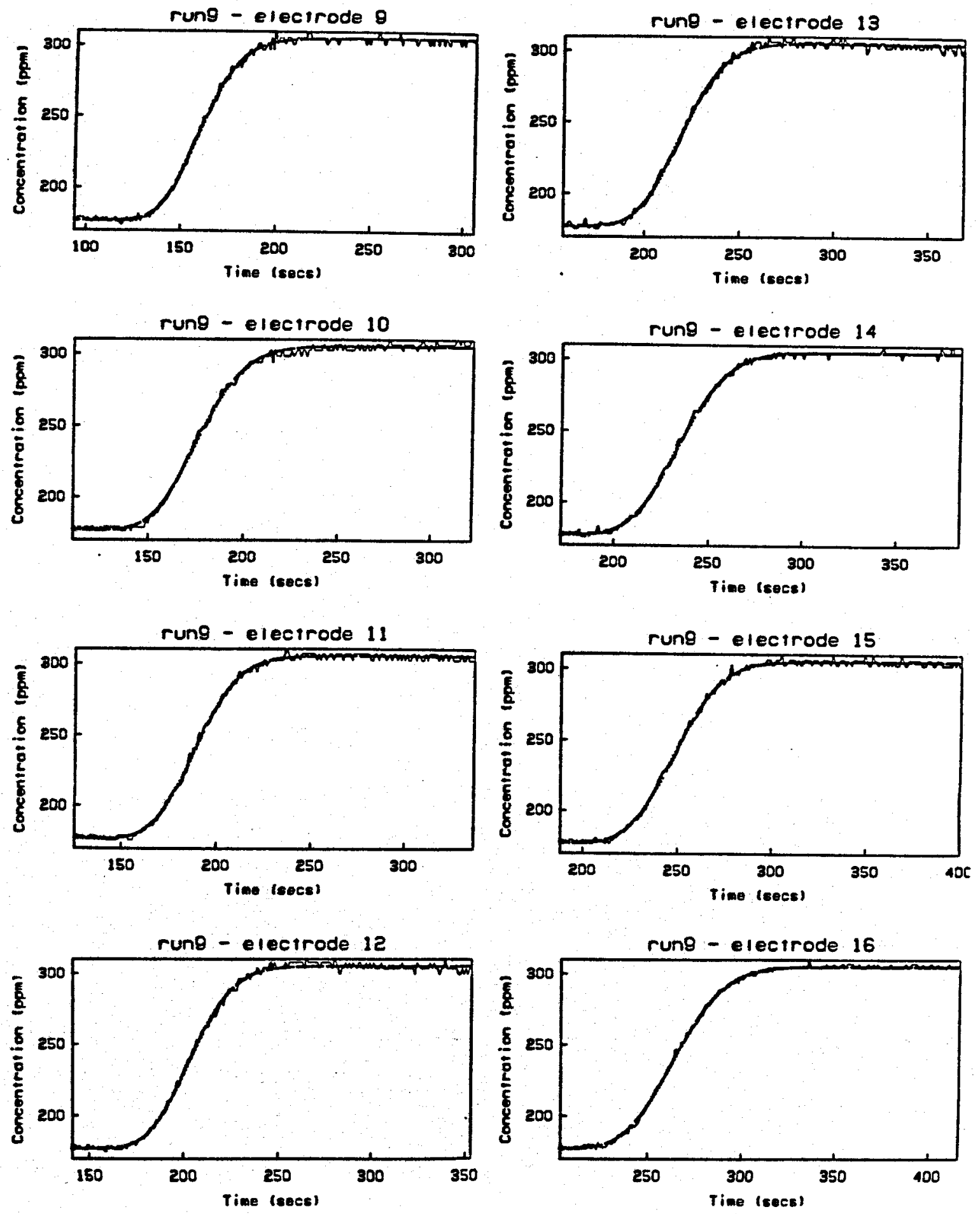

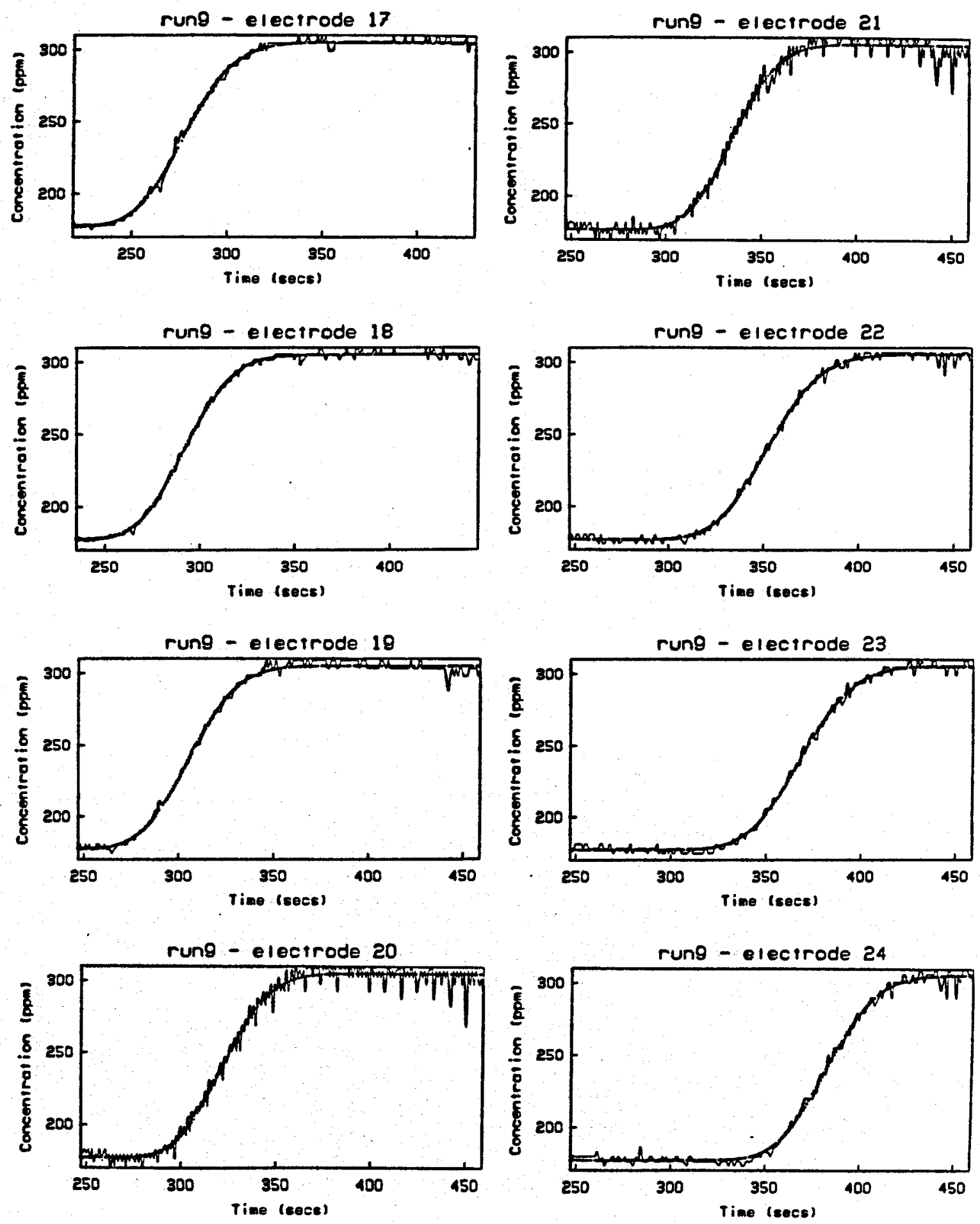

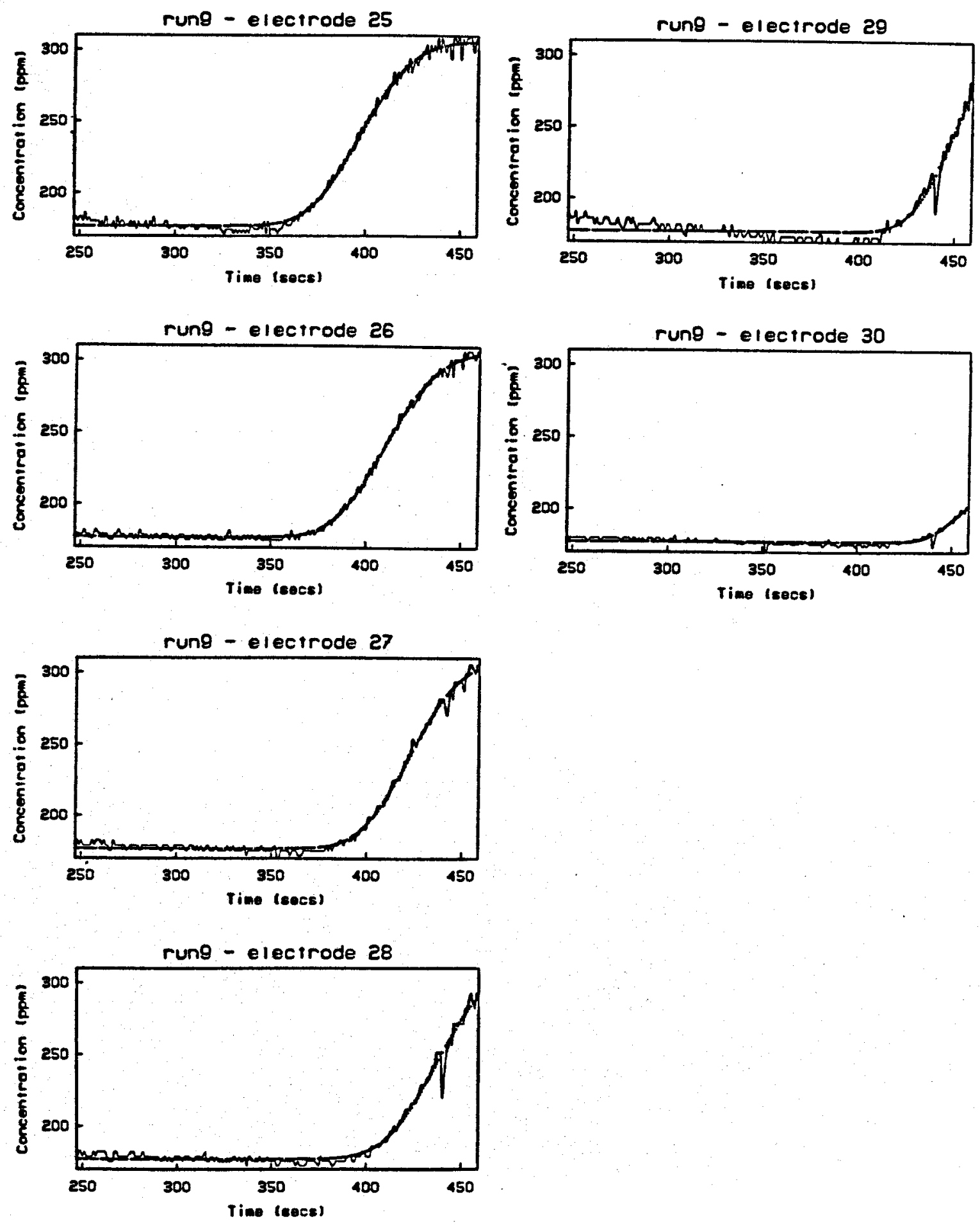


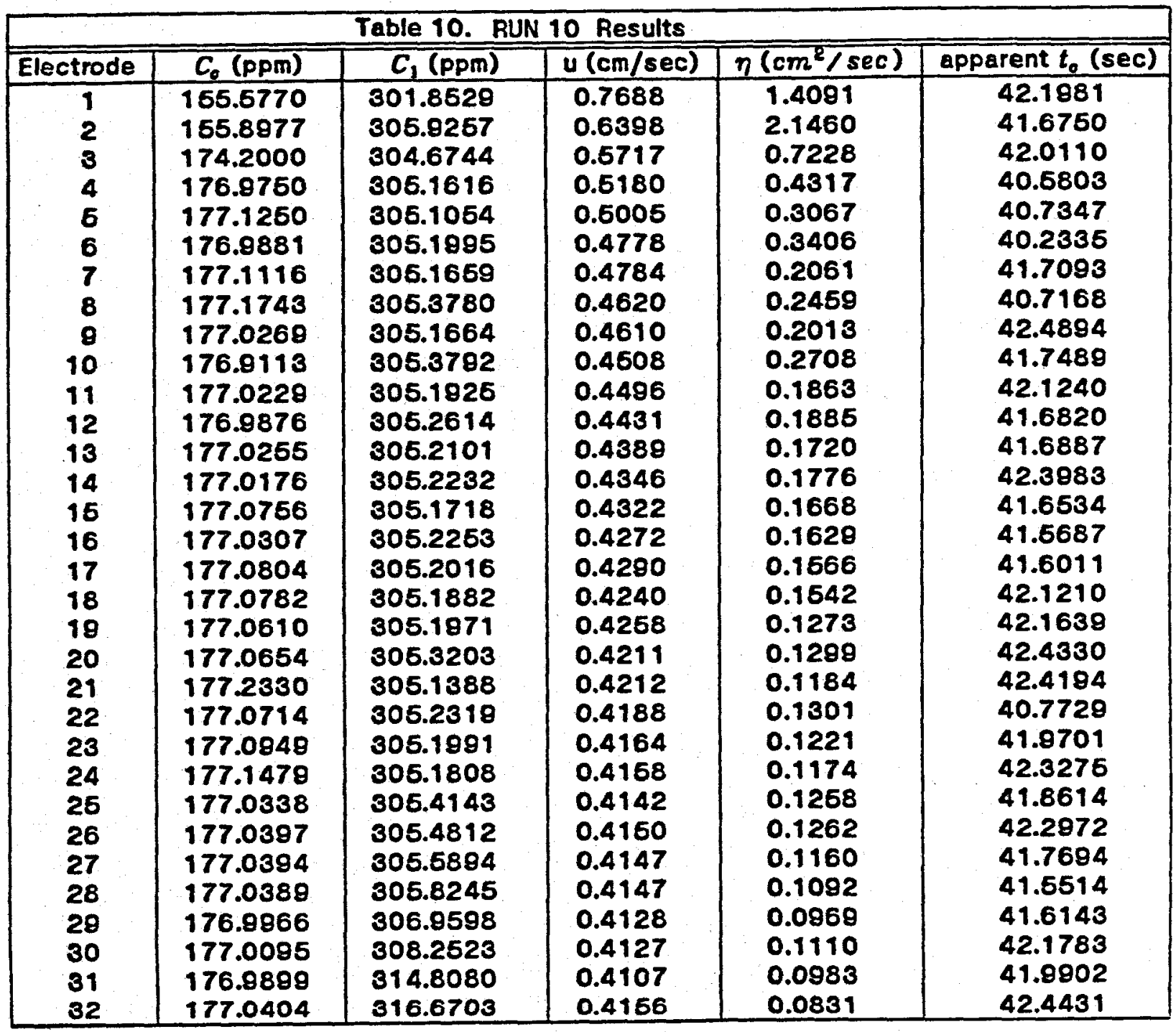

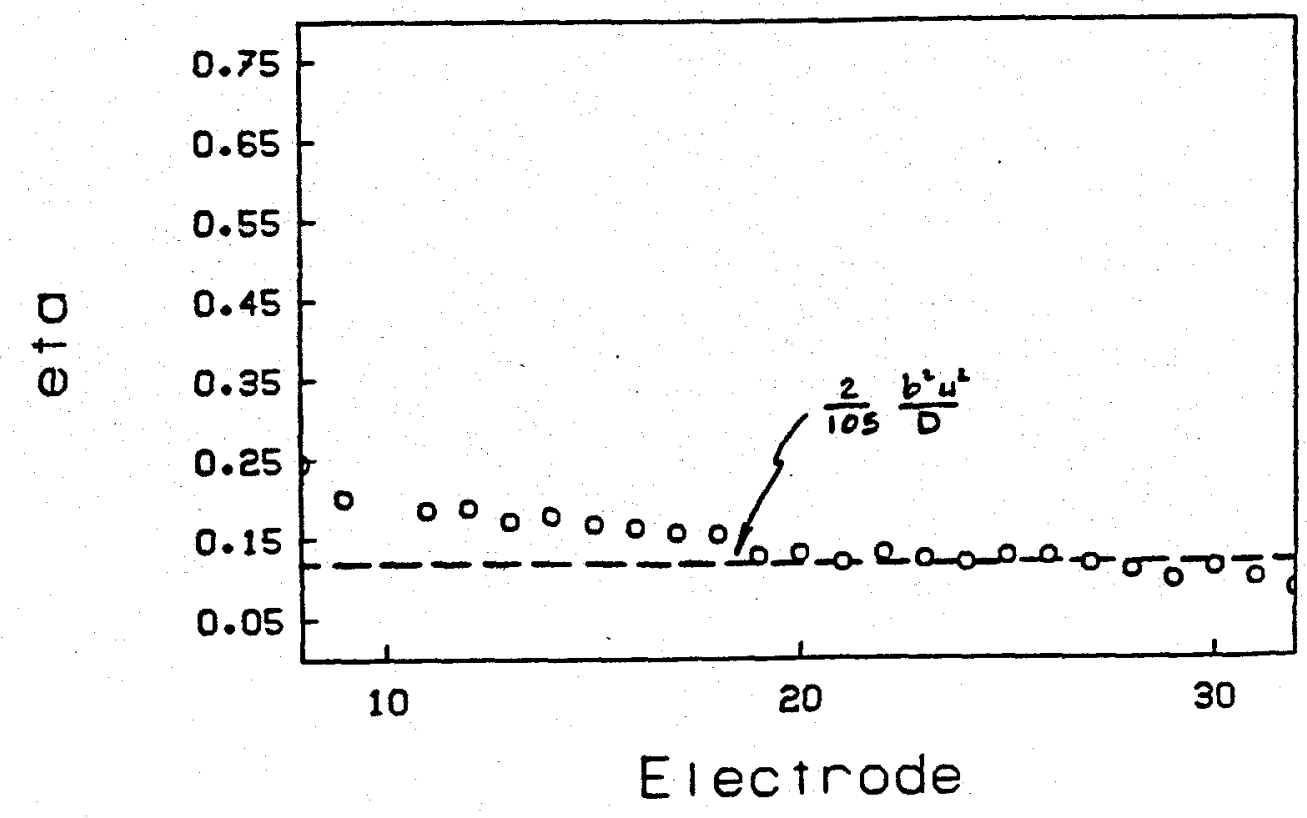

Fig. 14. Comparison of estimated and calculated dispersivity. Run 10. 

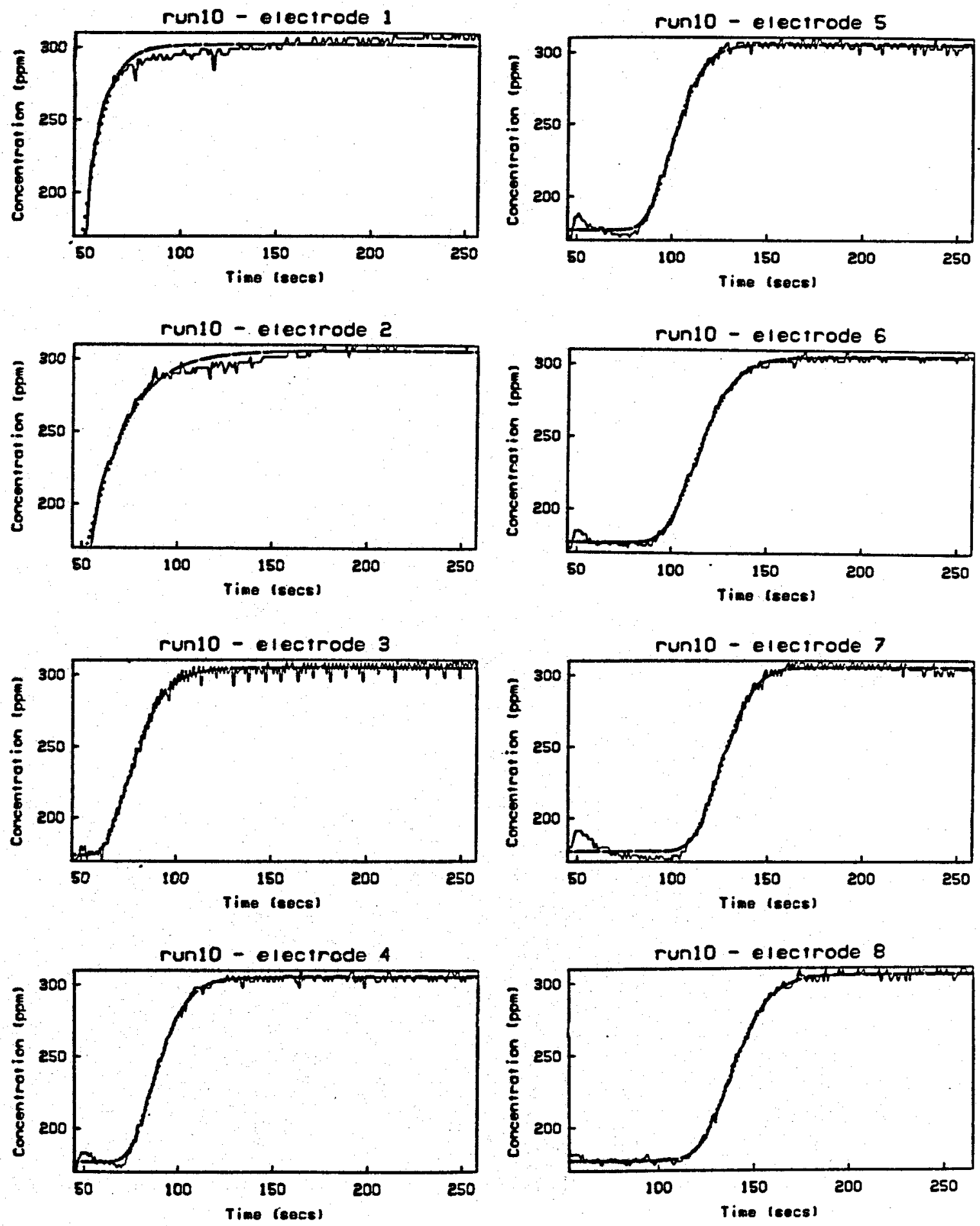

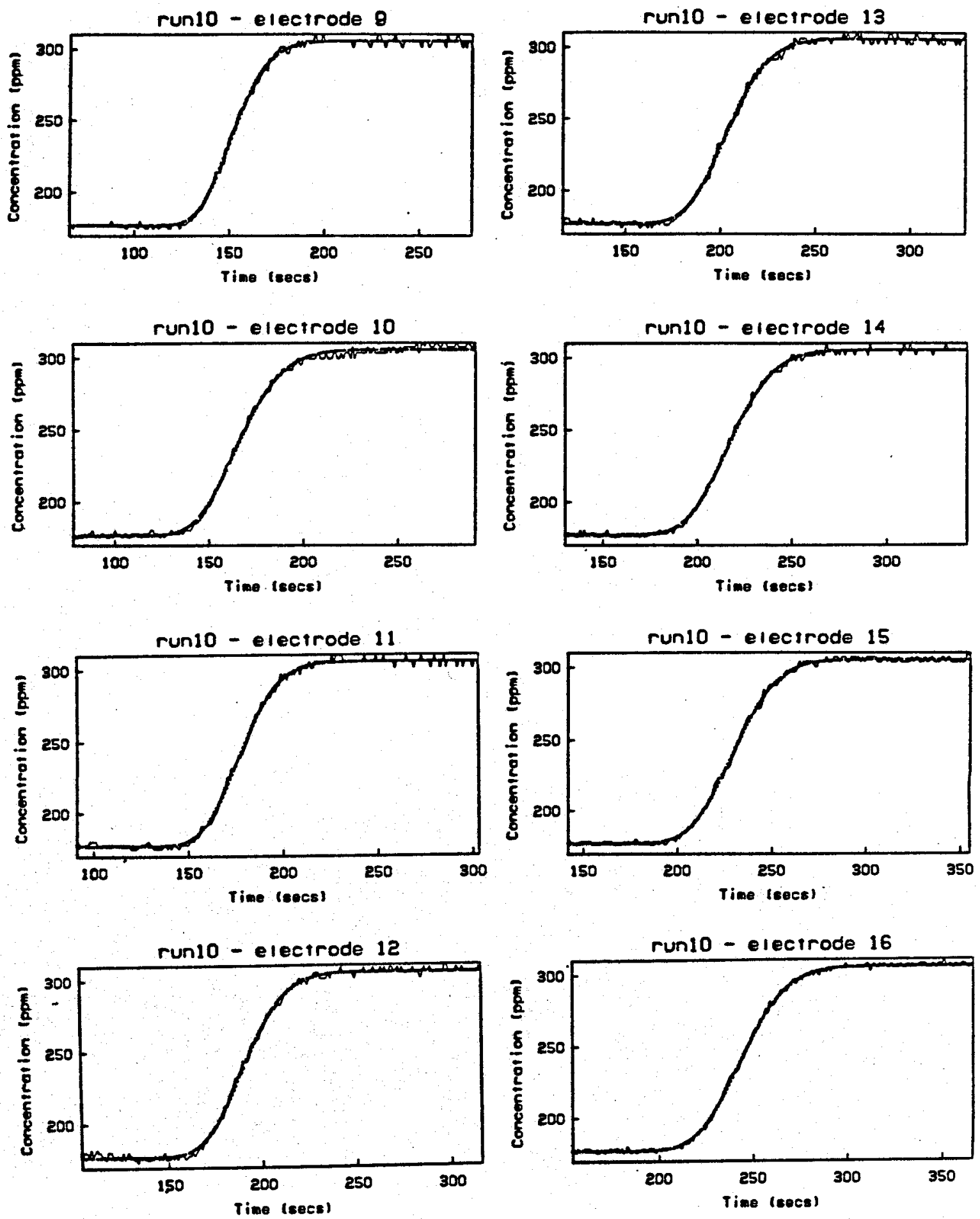

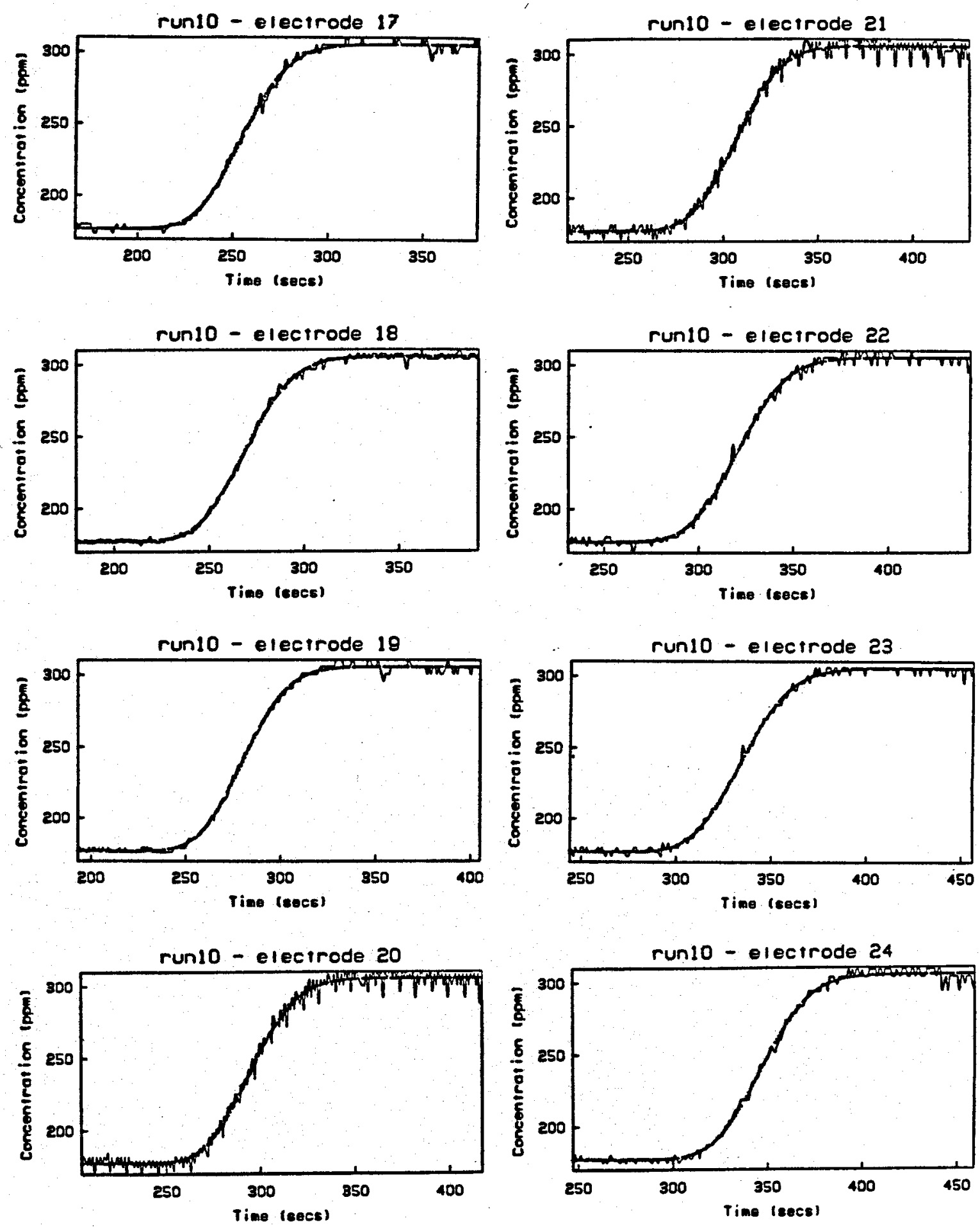

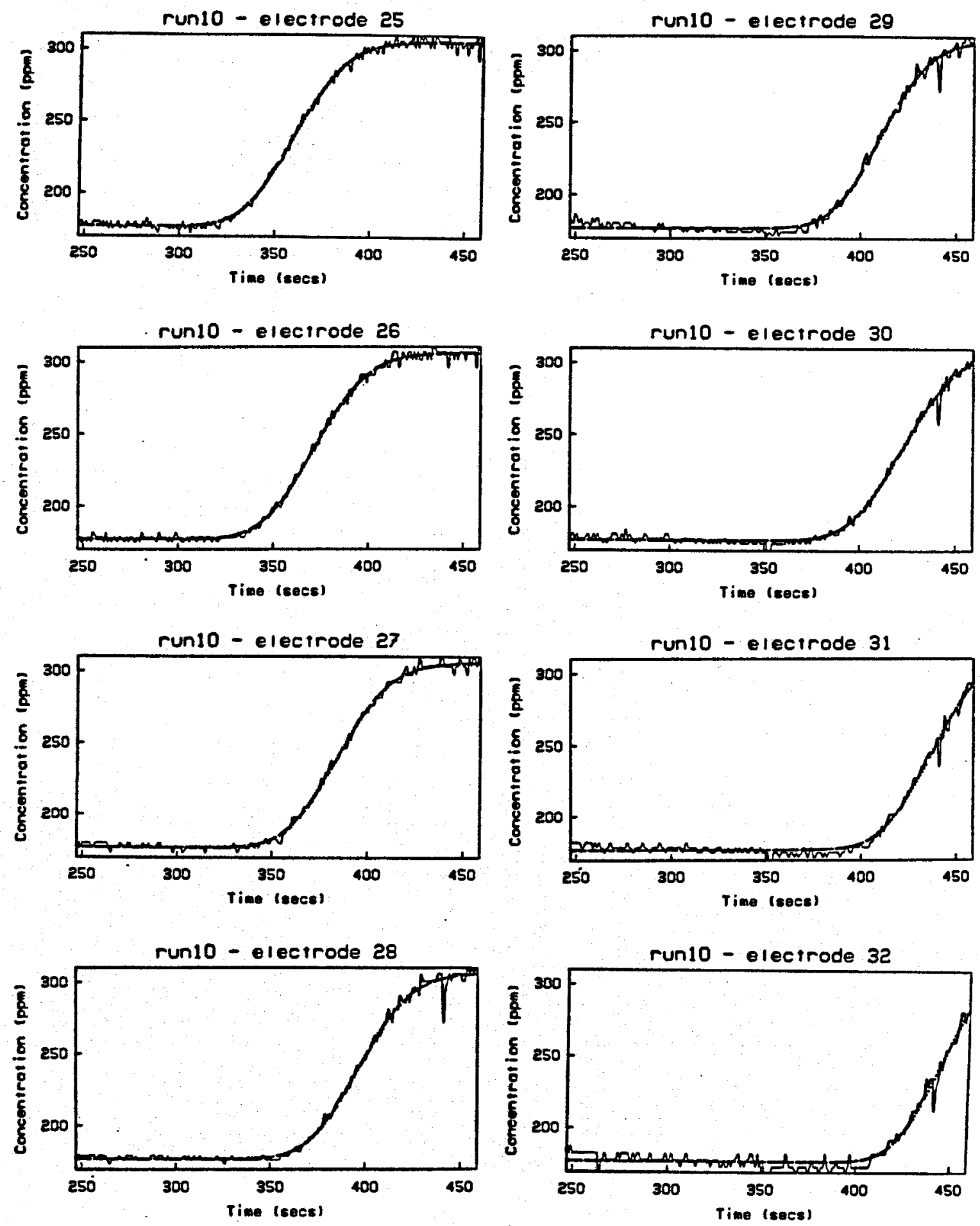


\section{Section 7: coNCLUSIONS}

The approximation for Taylor Dispersion, Equation (3), is sufficiently accurate to be used in a fracture flow model for tracer test analysis.

The slight decline of dispersivity with distance suggests that further studies may find a stricter criterium for the non-dimensional time before tracer front equalization. 
Section 8: RIIFERENCES

1. Bear. Jacob. Dynamics of Fluids in Porous Media . American Elsevier, New York, NY. 1972.

2. Bear, Jacob. "Some Experiments in Dispersion", J. Geoph. Res. ,Volume 66, no. 8. pp. 2455-2467.

3. Carslaw, H.S. \& Jaeger, J.C. Conduction of Feat in Solids . Oxford University Press, 2nd Ed., 1959.

4. Coats, K.H. "Dead End Pore Volume and Dispersion in Porous Media". Soc. Pet. Eng. Jour. , March 1964.

5. Davies, Cecil W. The Conductivity of Solutions . John Wiley \& Sons, Ine., New York. 2nd Ed. 1933.

6. Fossum, M.P. Tracer Analysis in a Fractured Geothermal Reservoir , Masters Report, Stanford University. June 1982.

7. Fossum, M.P. and Horne, R.N. "Interpretation of Tracer Return Profiles at Wairakei Geothermal Field Using Fracture Analysis", Geoth. Res. Counc., Transaction 6. 1982.

8. Horne, R.N. "Reservoir Engineering Aspects of Reinjection", Japan Geoth. Energy Assoc. Jour. , 19, 23-30, (1982). (in Japanese).

9. Horne, R.N. and Rodriguez, F. "Dispersion in Tracer Flow in Fractured Geothermal Systems", Geoph. Res. Let. , Vol. 10, no. 4, 289-292. 1983.

10. Hull, L.C. and Koslow, K.N. "Dispersion in Fracture Networks", Proc., Eighth Wkshp Geoth. Res. Engr.. Stanford University, Dec. 1982.

11. Taylor, Sir Geofirey, F.R.S. "Dispersion of Soluble Matter Flowing Slowly Through a Tube", Proc. Roy. Soc. , A 219, pp 186-203, 1953.

12. VARPRO, Computer Science Dept., Stanford University. 


\section{APPENDIX A: MULTIPLEXXER BOARD}

The multiplexer board contains circuitry which switches through the electrode array, allowing instantaneous voltage measurement at each location. Its design is described by the flow dagram of Fig. A.1.1.

The circuitry is capable of testing 128 electrodes, divided into 8 groups of 16. The computer selects a bank of 16 electrodes and the voltage across each is measured individually using a resistance bridge. The signal is amplified, converted to digital logic, and stored in OUTPUT.DAT for later processing.

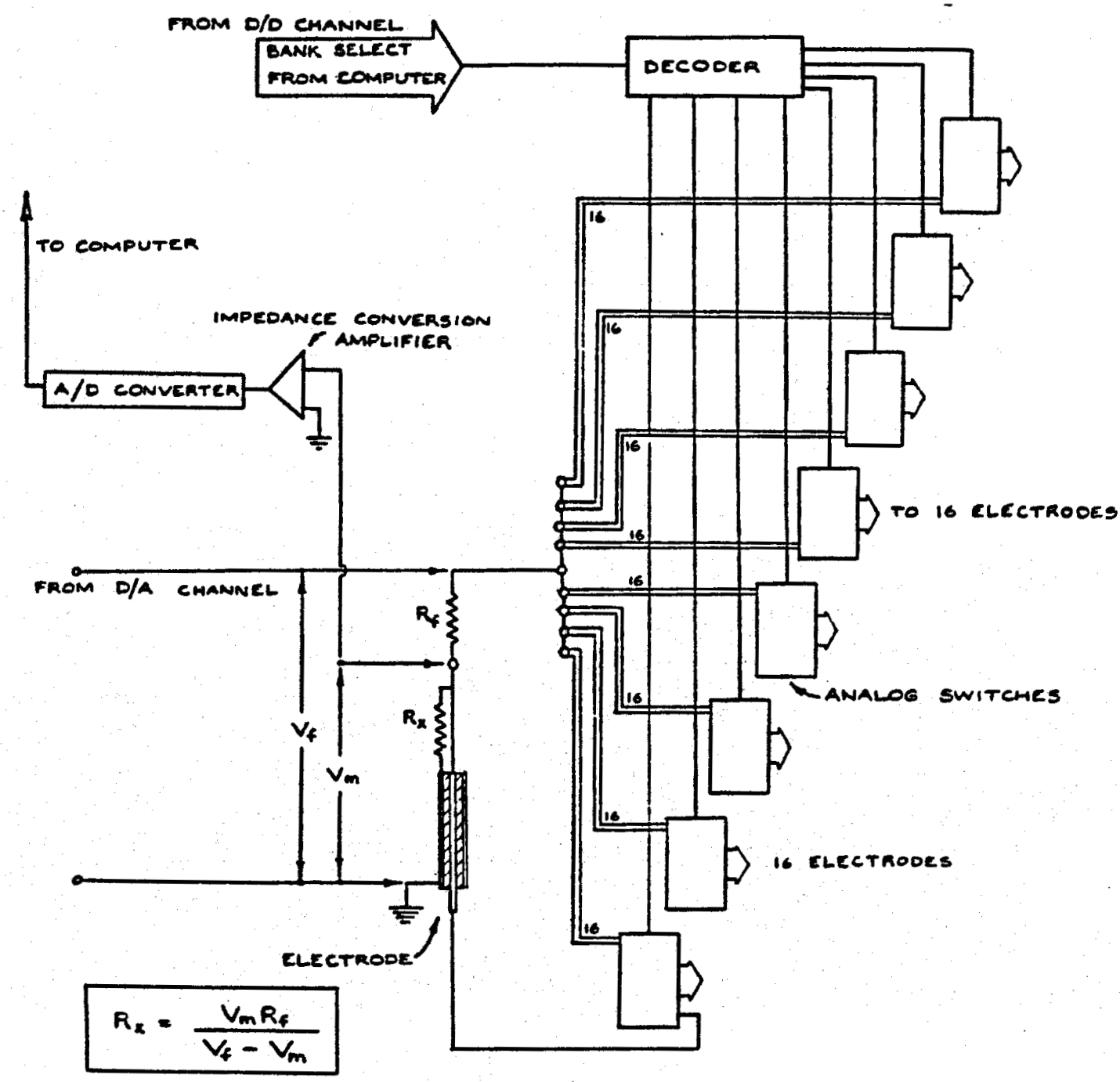

Fig. A.1.1. Multiplexer Board Design 
APPENDIX B: COMPUTER SCANNING ALGORITHMS

Figure B.1.1 shows a flow diagram describing the computer scanning algorithms used for data aquisition, transmission, curve fitting and plotting.

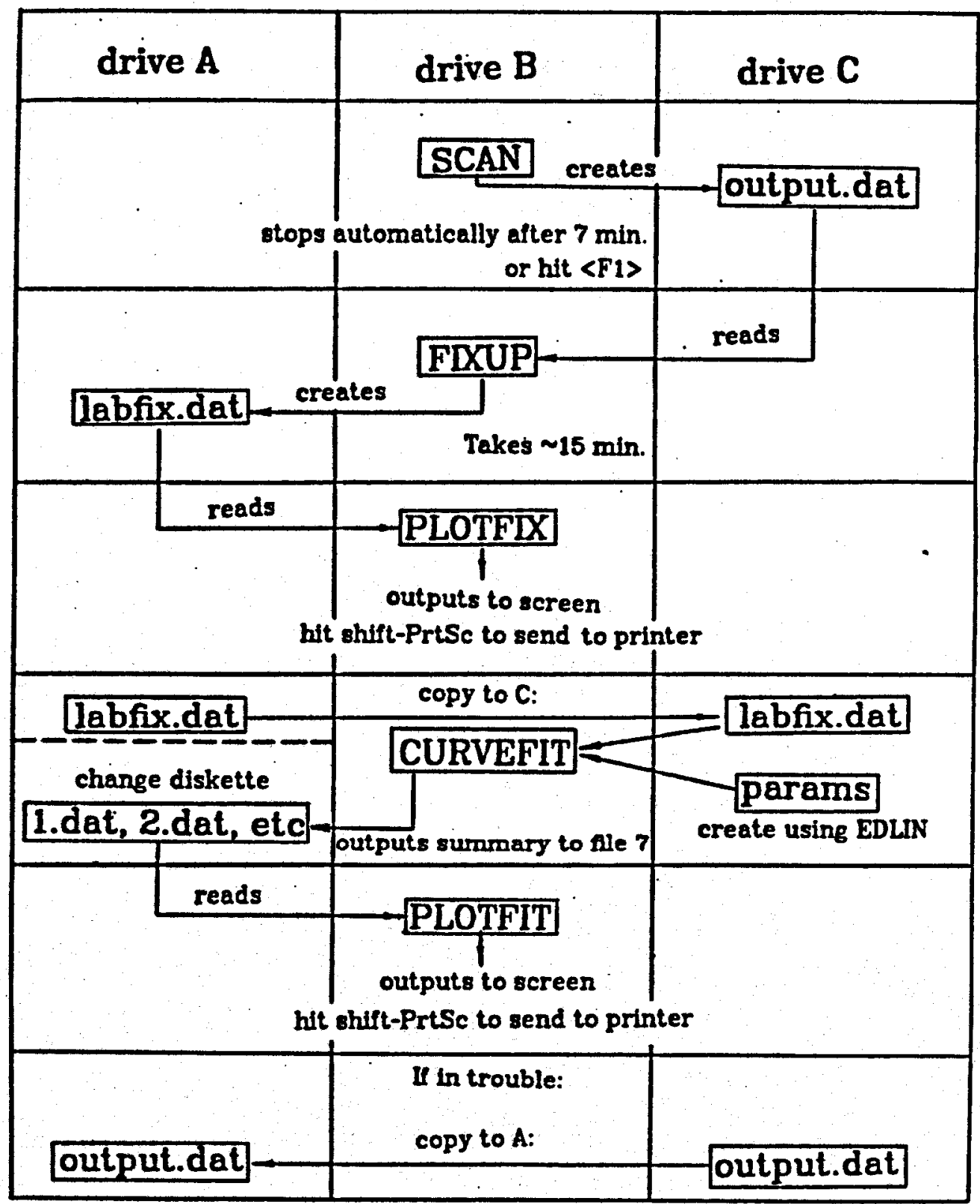

Fig. B.1.1. Computer Scanning Algorithms 
Appendix C: COMPUTER PROGRAMS AND SUBROUTINES

\section{Directory of Lab Control Diskette}

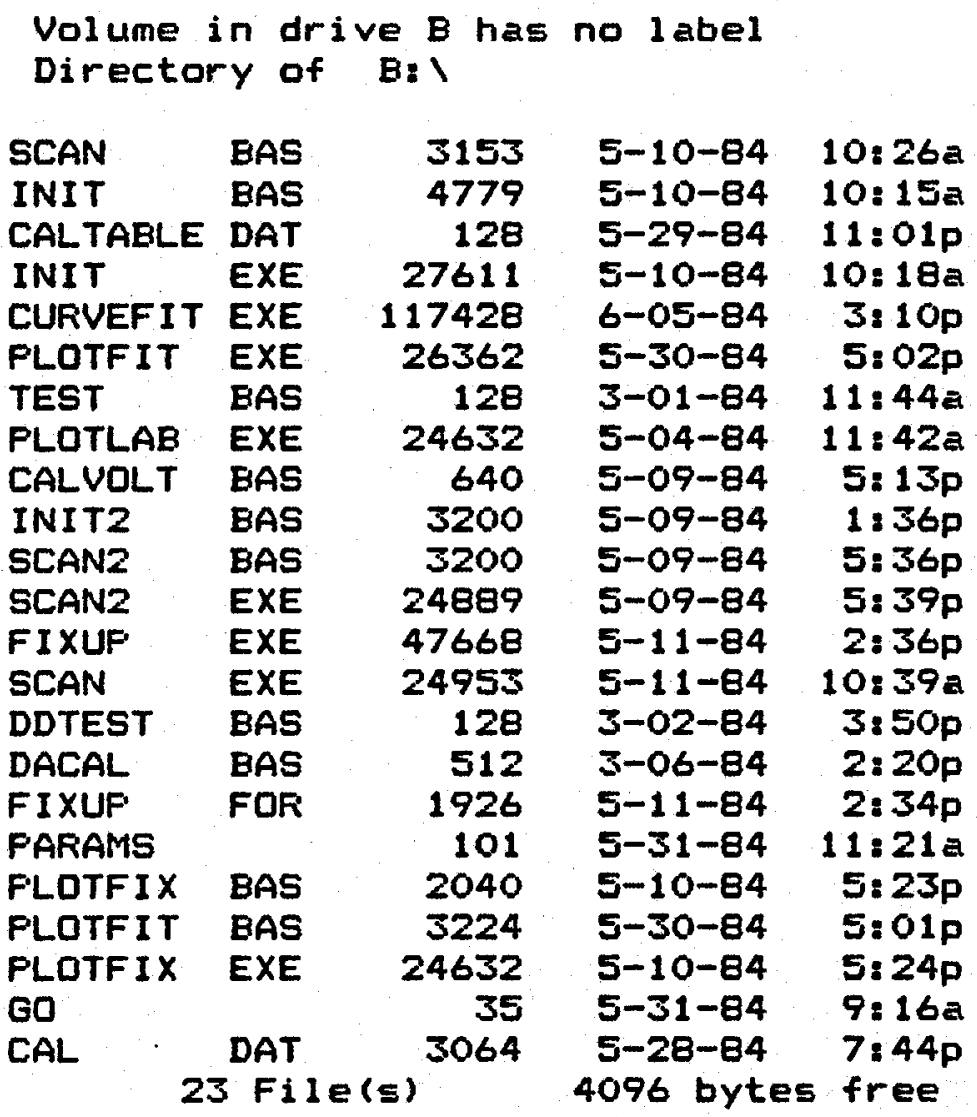




\section{SCAN}

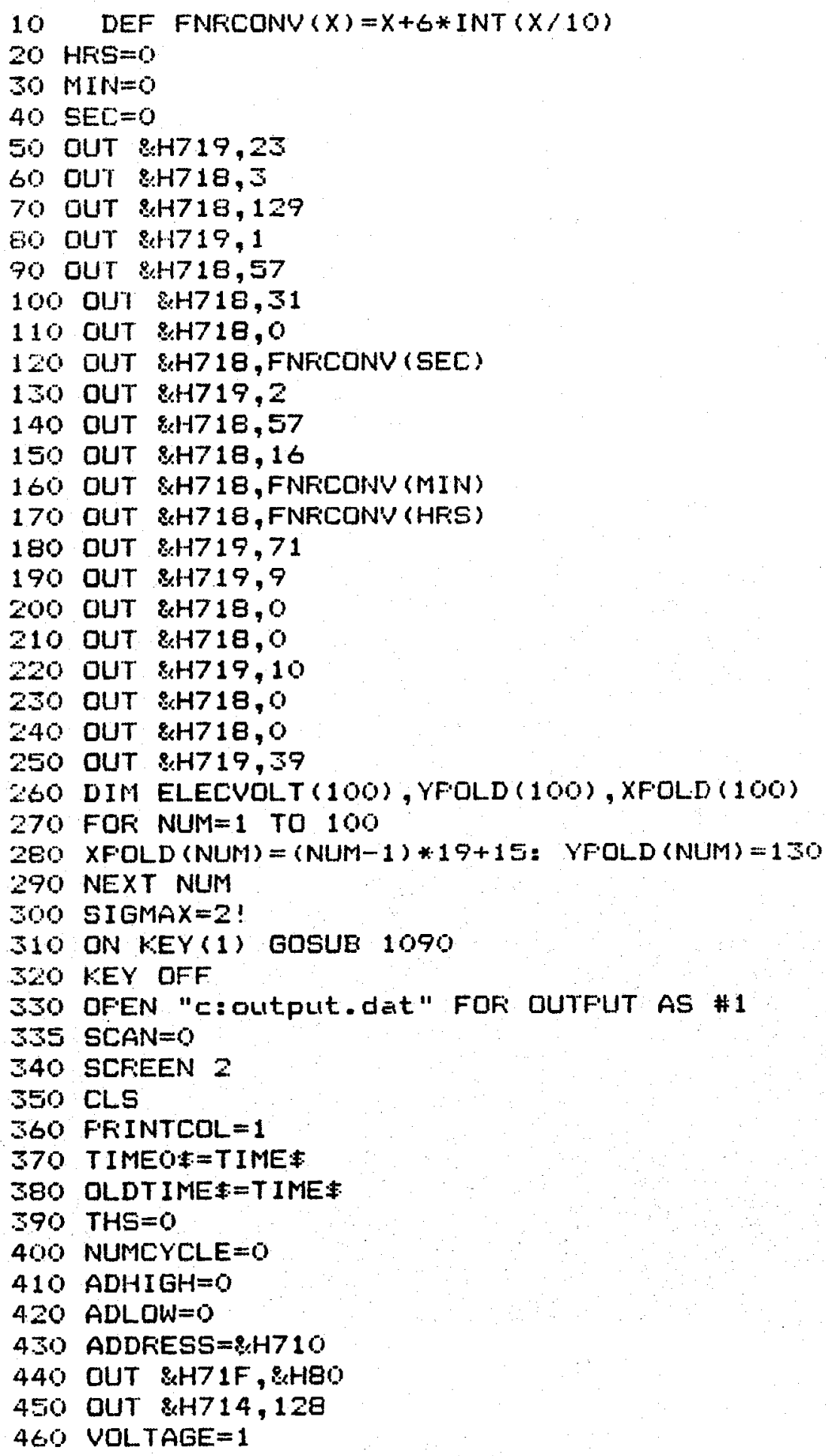




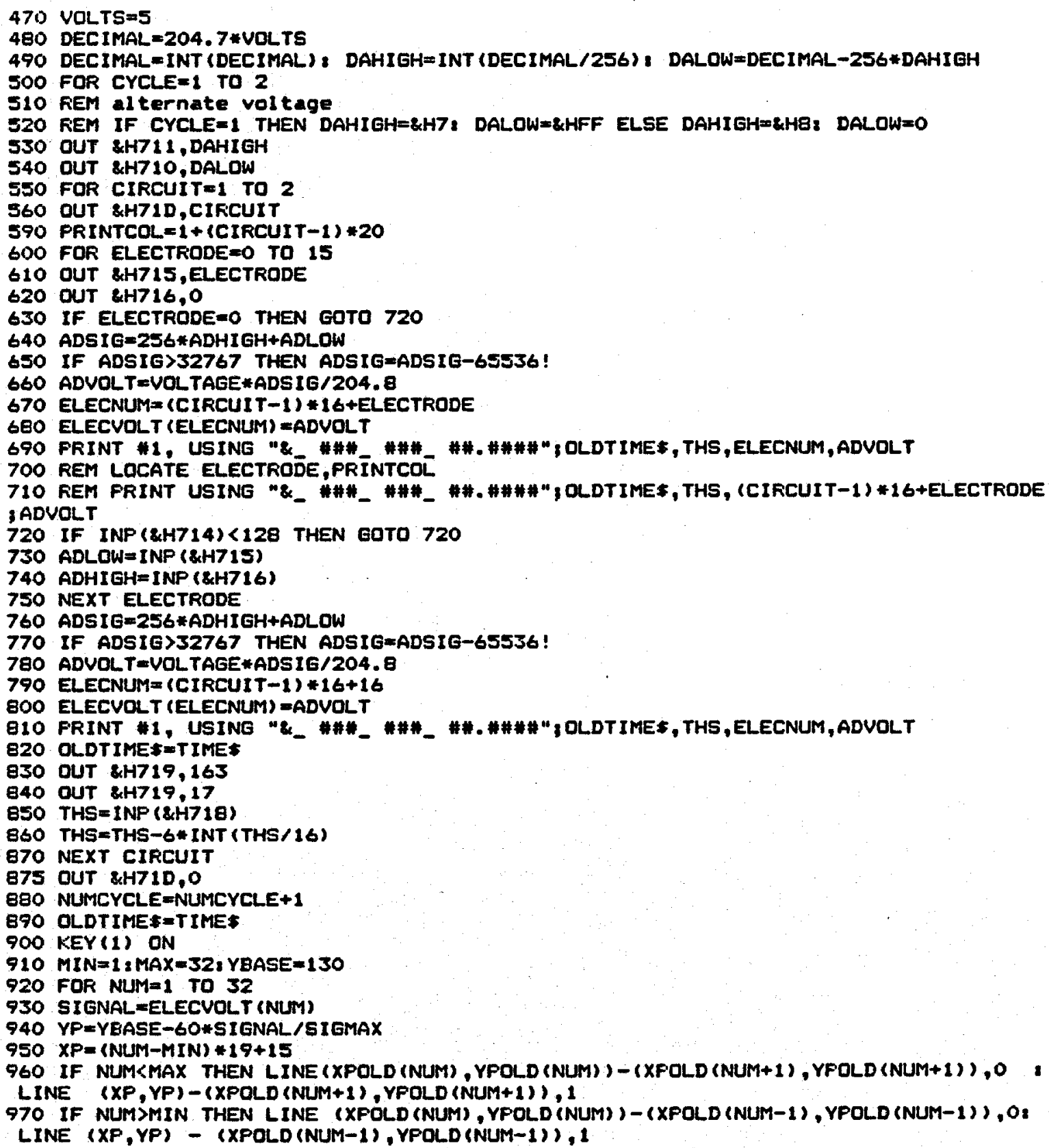


980 XFOLD (NUM) $=X F \&$ YFOLD (NUM) $=Y P$

990 REM IF NUMK17 THEN LOCATE NUM, 1 ELSE LOCATE NUM-16,40

1000 REM FRINT NUM-1, 5IGNAL

1010 NEXT NUM

1020 LINE (15, YBASE-60)-(624, YBASE-60)

1030 LINE (15, YBASE) - (624, YBASE)

1040 LINE (15, YEASE) - (15, YBASE-60)

1050 LINE (624, YBASE)-(624, YEASE-60)

1055 SCAN=SCAN+1, IF SCAN $>440$ THEN GOTO 1090

106O KEY (1) STOP

1070 NEXT CYCLE

1080 GOTO 500

1090 KEY (1) STOP

1100 CLOSE 1

1110 PRINT "start time",TIMEOs, "finish time",OLDTIME*, "No, of cycles" "NUMCYCLE

1120 STOP

\author{
FDXUP
}

COMMON /A/VOLT $(32,500)$

INTEGER ELEC, ELECN, HR, MIN, SEC, THS, RECND

DIMENSION TIME $(500)$, CTEL $(20), \operatorname{VTBL}(20,32)$

CALERT $=0$

IF (CALERT.EQ.0) GO TO 200

C Next section skipped if no calibration desired

OPEN (3,FILE='Cal . dat' "STATUS= 'OLD' ,ACCESS=' SEQUENT I AL') READ (3,103) NPTS

103 FORMAT (I2)

DO 10 ELEC $=1,32$

DO $11 \mathrm{~N}=1, \mathrm{NPTS}$

102 FORMAT (14,11X,F6.4)

CTEL $(N)=N D U M M Y$

11 CONTINUE

10 CONTINUE

$$
\text { END FILE } 3
$$

200 OFEN (1,FILE='cloutput.dat', status='old', access= 'direct'

\& reel $=24$, form= 'formatted')

READ $(1,100, R E C=1): H R, M I N$, SEC, THS, ELEC, SIG

100 FOFMAT $(12,1 X, 12,1 X, I 2,2 X, 12,2 X, I 2,2 X, F 6.4)$ 
TZERO=3600.*HR+60.*MIN+SEC

DD 1 ELEC $=1,32$

RECND=ELEC

$I=1$

3 READ ( 1,100, REC=RECNO, END=2) HR, MIN, SEC, THS, ELECN, SIG

IF (ELEC.EQ. 1) TIME $(I)=3600$. *HR+60.*MIN+SEC-TZERO

IF (CALBRT. NE. O) CONCN=CONVRT (SIG, NPTS, ELEC, CTBL, VTBL ( 1 , ELEC)) VOLT (ELEC, I) $=S I E$

C. write $(*, \cdot(f 7.1,1 \times, f 10.4) \cdot)$ time $(1)$, concn

$I=I+1$

RECNO=RECNO+32

GO TO 3

2 CONTINUE

WRITE (*, (I4) ) ELEC

1 CONTINUE

END FILE 1

OPEN (2,FILE='as labfix.dat' status "new', access"'sequential ')

DO 4 ELEC $=1,32$

DO $5 \quad I I=1, I$

WRITE (2,101) TIME (II), VOLT (ELEC, II)

101 FORMAT (F7.1,1X,F10.4)

5 CONTINUE

END FILE 2

STOP

END

FUNCTION CONURT (SIG, NPTS, ELEC, CTEL, V)

DIMENSION CTEL $(20), V(20)$

NFTS1 $=$ NPTS-1

IF (SIG.GT.V(1)) GO TO 1

DO $2 I=1$, NPTS1

IF (SIG.GT.V(I+L)) GO TO 3

2 CONTINUE

SLOPE $=1$. / (V (NPTS) $-V$ (NPTS-1) ) / (CTBL (NPTS) -CTBL (NPTS-1))

CONURT =CTBL (NPTS) +SLOPE* (V (NPTS) -STE)

RETUFN

$3 \quad$ SLOPE $=(C T B L(I+1)-C T E L(I)) /(V(I+1)-V(I))$

CONURT $=C T B L(I+1)+S L O P E *(S I G-V(I+1))$

RETURN

$1 \quad$ SLOFE $=(C T E L(2)-C T E L(1)) /(V(2)-V(1))$

CONURT $=$ CTEL $(1)+$ SLQPE* (SIG-V(1))

RETURN

END 


\section{PLOTYTT}

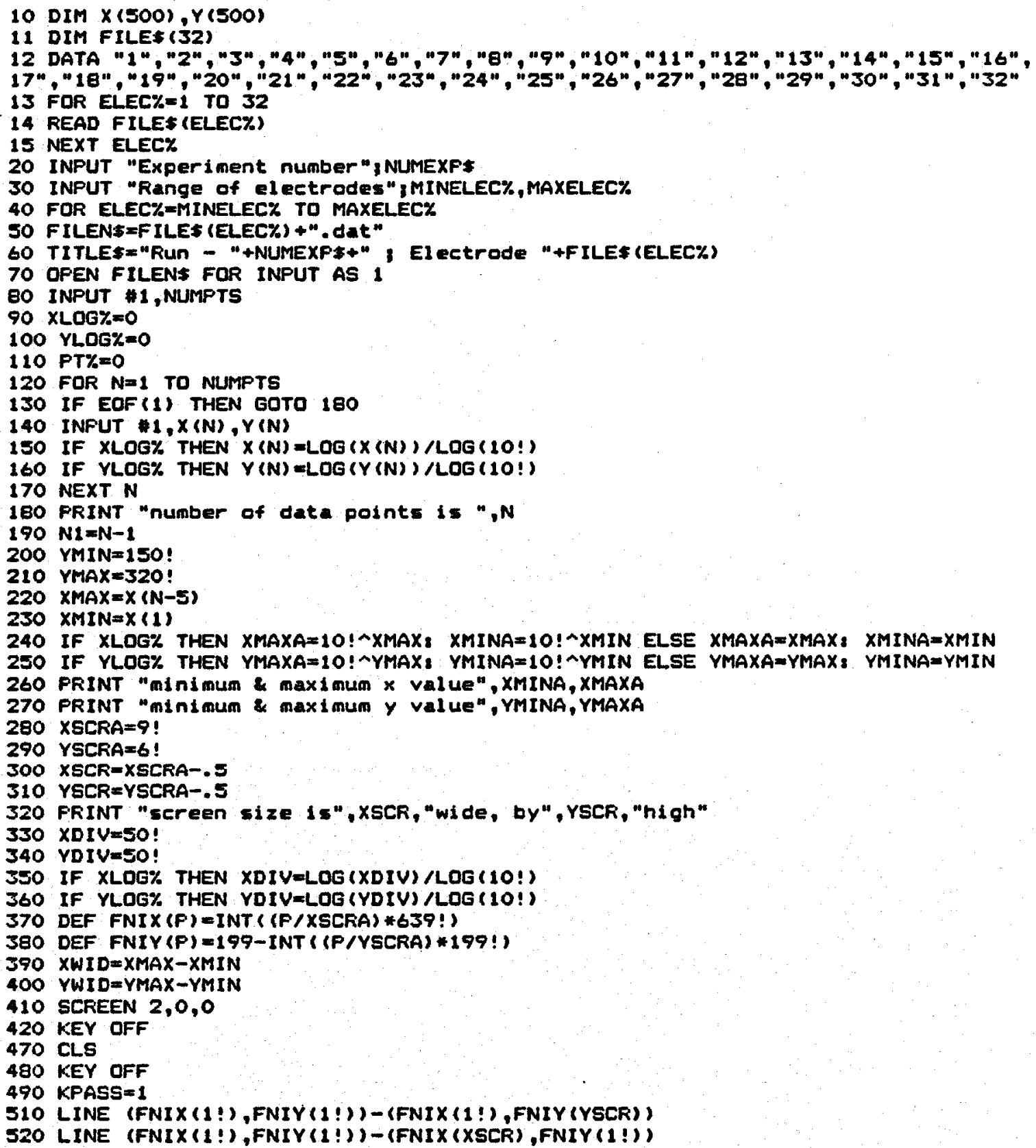




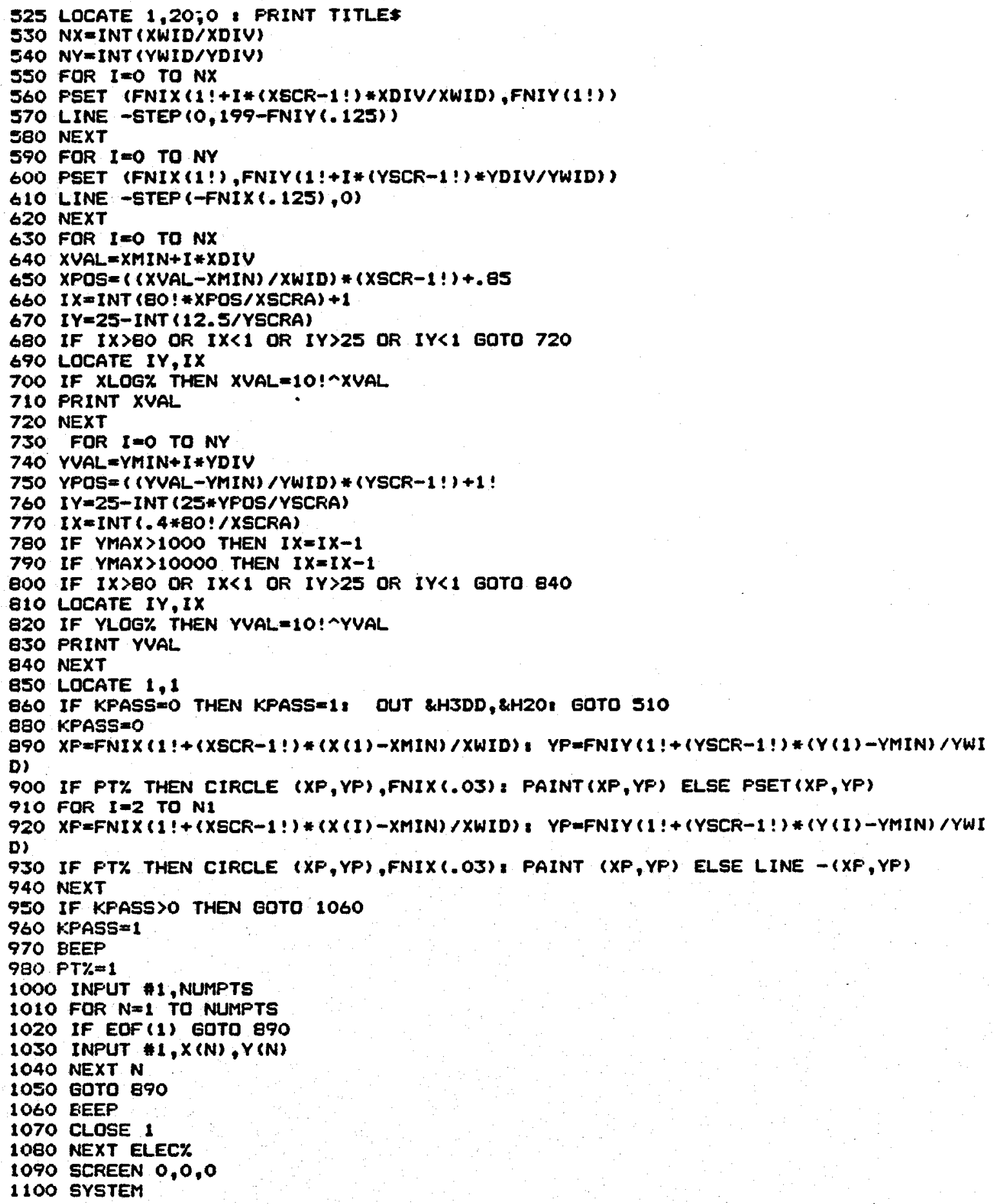


PLorTtX

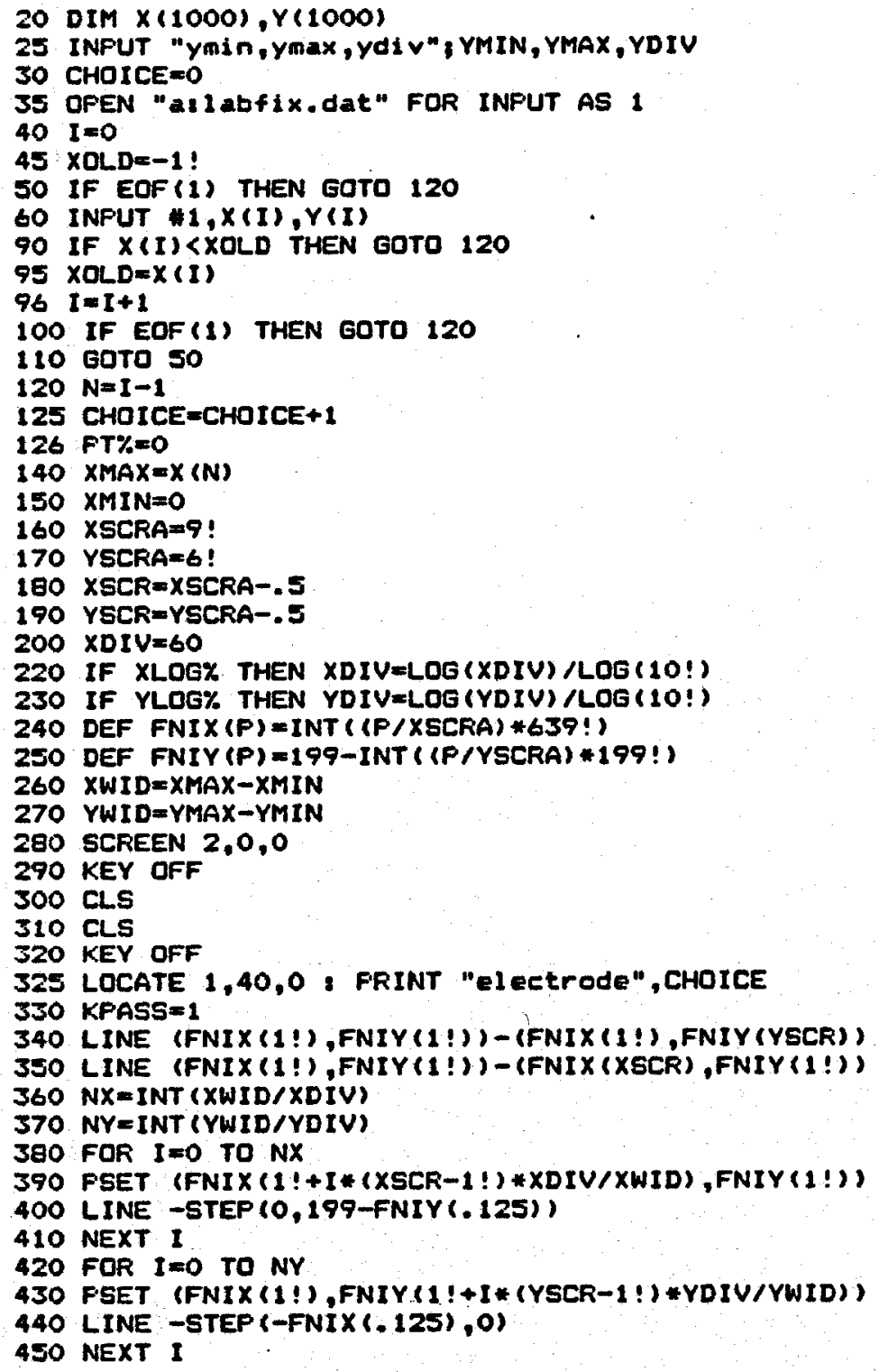




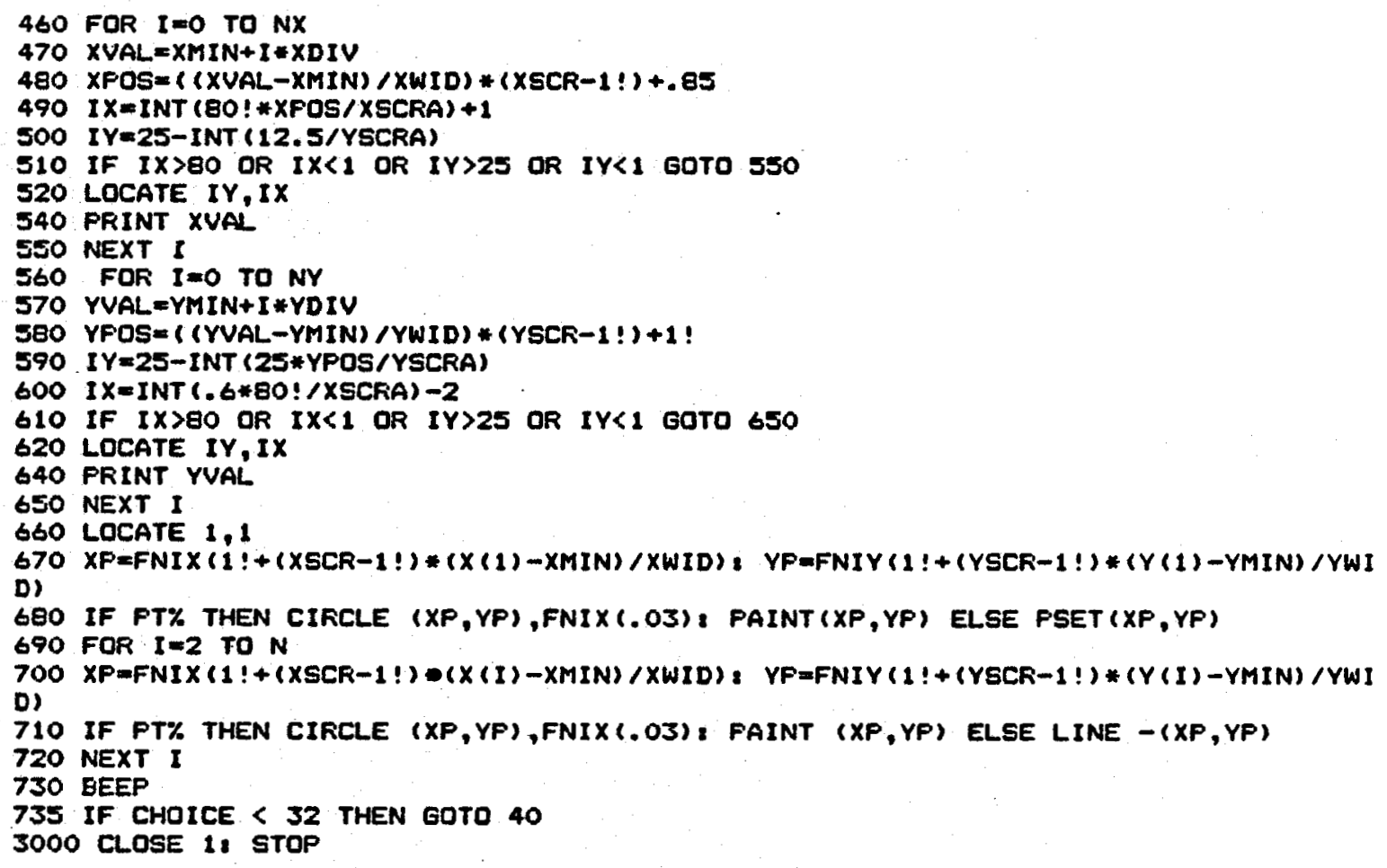


$C$
$C$
$C$
$C$
$C$
$C$
$C$
$C$
$C$
$C$
$C$
$C$
$C$

C
$C$
$C$
$C$
$C$
$C$
$C$
$C$
$C$
$C$
$C$
$C$

*******************************************************************1

FROGRAM BEGINS -Gilardi experiment analysis

IMPLICIT REAL*B(A-B,D-H,D-Z)

C

C

SET DIMENSIONS FOR VARFRO. BE CAFEFUL WHEN SETTING THE DIMENSIONS FOR THE INCIDENCE MATRIX INC. SEE NOTE.

DIMENSION $Y(500), T(500), A L F(3)$, BETA $(2), W(500), A(500,7)$, * INC $(12,8), N E L T R Y(32), N G O(32)$

COMMON XFOS,TZERO

COMMON /DUMMY/C $(500,6)$

EXTERNAL ADA

CHARACTER*G CFILE (32)

DATA CFILE/'1.dat', '2.dat', '3.dat','4.dat','5.dat',

e '6.dat',7.dat', '8.dat','9.dat',

1 '10.dat','11.dat','12.dat','13.dat','14.dat','15.dat',

'16.dat', 17.dat', 18.dat', 19.dat',

2 '20.dat', '21.dat','22.dat','23.dat','24.dat', '25.dat',

'26.dat','27.dat','28.dat','29.dat",

C

3. '30.dat', '31.dat', 32.dat'/

c

C

C

$$
\text { SET PARAMETERS FOR VARPRO. }
$$

IFLDT $=0$

NMAX $=500$

IFRINT $=50$

C

C

C

C

C

C

C

C

C

C

FIEAD $(5,311) \mathrm{NL}$

READ DATA SEQUENTIAL ORDERING AND PROPER FORMATTING ARE IMPORTANT.

NL IS THE NUMEER OF NONLINEAR FAFAMETEFS

311 FORMAT (I1)

WFITE $(6,12)$ NL

12 FOFMAT ( 1 HO, $10 \mathrm{X}$, 'NUMBER OF NONLINEAR FARAMETERS $/ / /(13)$ )

C

C

C

C

L IS THE NUMEER OF LINEAR PARAMETEFS

C

C 
c

C

ESTIMATES DF THE NONLINEAR FARAMETERS

C

$P O S O=9.8425$

310

READ $(5,310)$ VELOC, DIFFS, TZEFO, DCO,DC 1

FORMAT (F10.4)

READ $(5,312)$ NTRIES, (NELTRY $(K), k=1$, NTRIES)

312 FORMAT (33I2)

DO $314 K=1,32$

$314 \quad N G O(K)=1$.

DO $313 K=1$, NTRIES

$313 \quad$ NGO (NELTRY (K)) $=0$.

WRITE $(6,20)$ VELOC,DIFFS, TZEFO

20

FORMAT ( $/, 0$ Mean Velocity (cm/sec) Diffusivity (cmz/sec)'

\# 'Time zero (sec),$/,(5 X, F 9.5,18 X, F 13.3,10 X, F 10.3$ ) )

c

C

\section{$L P F 2=L+N L+2$}

c

c

C

C

$N$ IS THE NUMBEF DF OBSEFIVATIONS

IV IS THE NUMBER OF INDEPENDENT VARIABLES $T$

IV $=1$

C

C

C

C

C

C

C

C

C

$T$ IS THE INDEFENDENT VARIABLE

$Y$ IS THE N-VECTOR OF OBSEFVATIONS

WRITE $(7,323)$

323

FORMAT $(2 X$, 'EleC

2

Di sp

$\mathrm{cm} / \mathrm{sec}$

DO 200 NELEC $=1,32$

$\mathrm{N}=\mathrm{O}$

TOLD $=0$.

$203 \quad N=N+1$

READ $(4,301, E N D=202) T(N), Y(N)$

301 FORMAT (2F10.4)

IF (TOLD.GT.T(N)) GO TO 202

TOLD $=T$ (N)

202 $N=N-5$

GD, TO 203

IF (NGO(NELEC).GT.0) GO TO 200

WRITE $(6,320)$ NELEC

320 FOFMAT $(/ /, 2 X, \cdot$ El ectrode number ',I3, $* * * * * * * * * * * * * * * * * \cdot)$ $X P O S=P O S O+5.08 *(N E L E C-1)$

$A L F(1)=V E L D C$

$A L F(2)=D I F F S$

ALF (3) $=$ TZERO 
W(I) ARE THE WEIGHTING FARAMETERS

C

C

DO $1 I=1, N$

c

$W(I)=1.0$

\section{IMINP=ID INT (TZEFID+XPOS/VELOC) - 100 \\ IMIN=IDINT (TZERD) \\ IF (IMIN.LT.IMINF) IMIN=IMINP}

IF (IMIN.GT.N-200) IMIN=N-200

$N=N-I M I N$

IF (N.GT. 200) $N=200$

DO $201 I=1, N$

$T(I)=T(I M I N+I)$

$Y(I)=Y(I M I N+I)$

C WRITE $(6, *) T(I), Y(I)$

201 CONTINUE

CALL VARFRO IL, NL, N, NMAX, LFPZ, IV, T, $Y, W, A D A, A$,

c * IFRINT, ALF, BETA, IERR, 10)

$V O=B E T A(1)$

$V 1=B E T A(1)+2 . * B E T A(2)$

$B P A R=\left(V_{1}-V O\right) / D L D G(D C O / D C 1)$

$A P A R=V 1+B P A R * D L D G(D C 1)$

DO $211 I=1, N$

$211 \quad Y(I)=D E X P((A P A F-Y(I)) / B P A R)$

CALL VARFRO ( $L, N L, N, N M A X, L F F 2, I V, T, Y, W, A D A, A$,

C * IPFINT, ALF, BETA, IERR, 100)

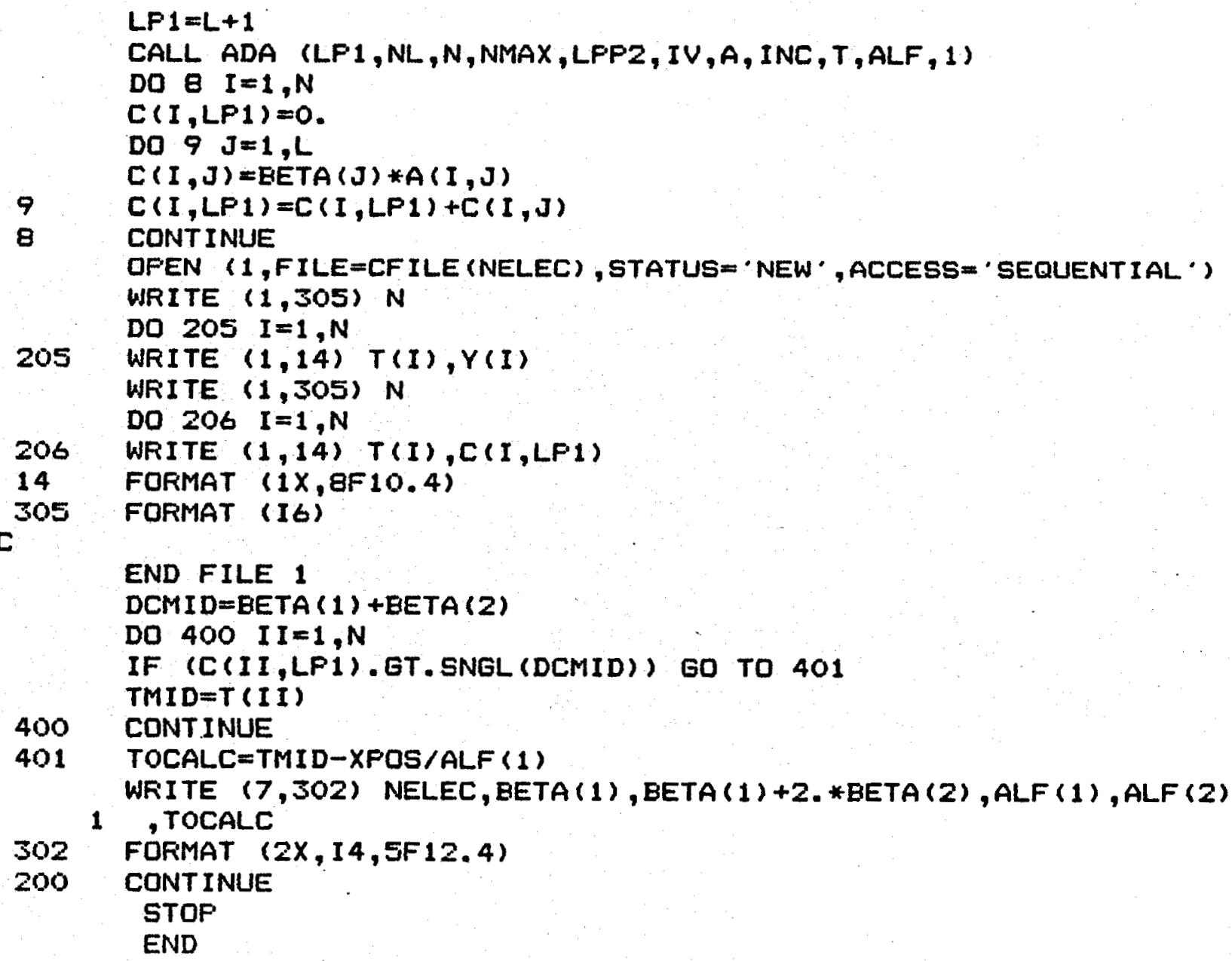




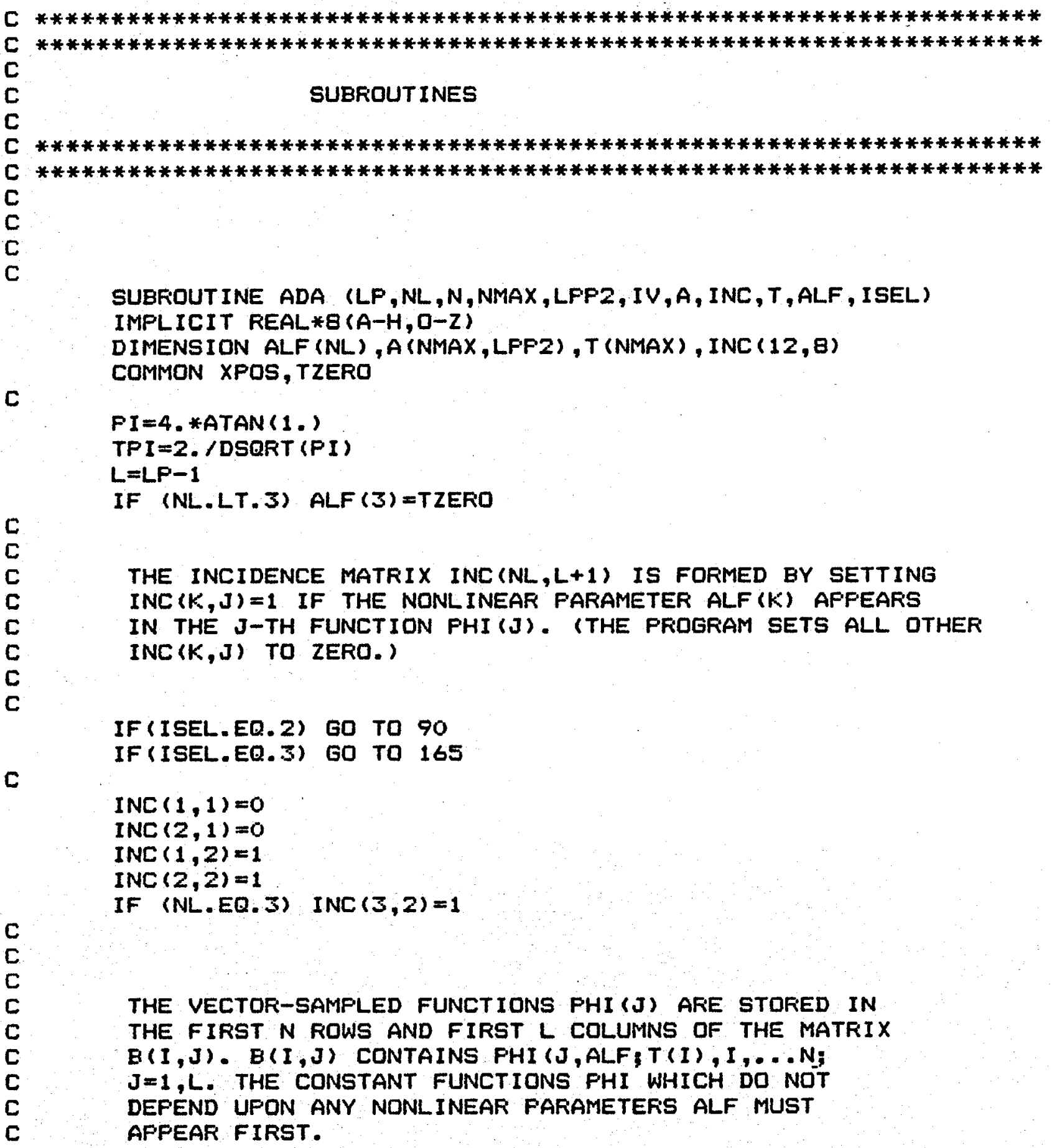

$\operatorname{INC}(1,1)=0$

$\operatorname{INC}(2,1)=0$

$\operatorname{INC}(1,2)=1$

$\operatorname{INC}(2,2)=1$

IF (NL.EQ.3) INC $(3,2)=1$

THE VECTOR-SAMPLED FUNCTIONS PHI (J) ARE STORED IN THE FIRST $N$ ROWS AND FIRST L COLUMNS OF THE MATRIX $E(I, J) . B(I, J)$ CONTAINS PHI $(J, A L F, T(I), I, \ldots N$; $J=1, L$. THE CONSTANT FUNCTIONS PHI WHICH DO NOT DEPEND UPON ANY NONLINEAR FARAMETEFS ALF MUST APPEAR FIRST.

C

C

C

C

C

C

C

C

C

C

C

C

C

C

C 
90

DO $81 I=1, N$

IF (ISEL.EQ. 1$) \quad A(I, 1)=1.0$

$A(I, 2)=0$.

$\operatorname{TTI}=T(I)-A L F(3)$

IF (TTI.LE. O.) GO TO 81

TFUNC $=$ DSQRT $(A L F(2) *$ TTI $)$

$A(I, 2)=D E R F C((X P O S-A L F(1) * T T I) /(2$ * *TFUNC $))$

IF (XPQS*ALF (1)/ALF (2).GT. 20.) A(I, 2) =A $(I, 2)+D E X P$ (ALF

1

(1)*XPOS/ALF (2))*DERFC $((X P Q S+A L F(1) * T T I) /(2$ * *TFUNC $))$

c

c

81 CONTINUE

C

$\mathrm{C}$

IF (ISEL.EQ.2) GO TO 200

C

C

c

C

C

C

C

DO $170 \quad I=1, N$

C

$A(I, 4)=0$.

$A(I, 5)=0$.

$A(I, 6)=0$.

$\operatorname{TTI}=T(I)-A L F(3)$

IF (TTI.LE.O.) GO TO 170

$E 1=\operatorname{DEXP}(-((X F O S-A L F(1) * T T I) * * 2) /(4 . * A L F(2) * T T I))$

E2 $=D E X P(-((X F O S+A L F(1) * T T I) * * 2) /(4 . * A L F(2) * T T I))$

$E 3=0$.

IF (ALF (1)*XFOS/ALF (2) . LT. 20.) ES=DEXP (ALF (1)*XFOS/ALF (2))

ERF $1=D E R F C((X F O S+A L F(1) * T T I) /(2 . * D S Q R T(A L F(2) * T T I)))$

FUNC $=2$. *DSQRT (TTI*ALF $(2) * * 3)$

$A(I, 4)=-T P I * E I *(-T T I /(2 . * D S Q R T(A L F(2) * T T I)))$

IF (E3.GT.0.) A $(I, 4)=A(I, 4)+(X P Q S / A L F$

(2))*E3*ERF 1 +E3*(-TPI*E2)*TTI/(2.*DSQRT (ALF (2)*TTI))

$A(I, 5)=$ TPI $* E 1 *(X P O S-A L F(1) * T T I) / F U N C$

IF (E3.GT.0.) $A(I, 5)=A(I, 5)-E 3 * E R F 1 * A L F(1) * X F O S$ /

1 ALF (2)**2+E3*TPI*E2*(XFOS+ALF (1)*TTI)/FUNC

IF (NL.LT.3) GO TO 170

$A(I, 6)=-T P I * E 1 *(X F O S /(2 . * D S Q R T(A L F(2) * T T I * * 3))+A L F(1) /$

1 FUNC)

IF (ES.GT.0.) $A(I, 6)=A(I, 6)+E 3 *(-T P I * E 2)$

2

* (XFOS/ (2.*DSQFT (ALF (1)*TTI**3))-ALF (1)/FUNC)

$\mathrm{C}$

C 


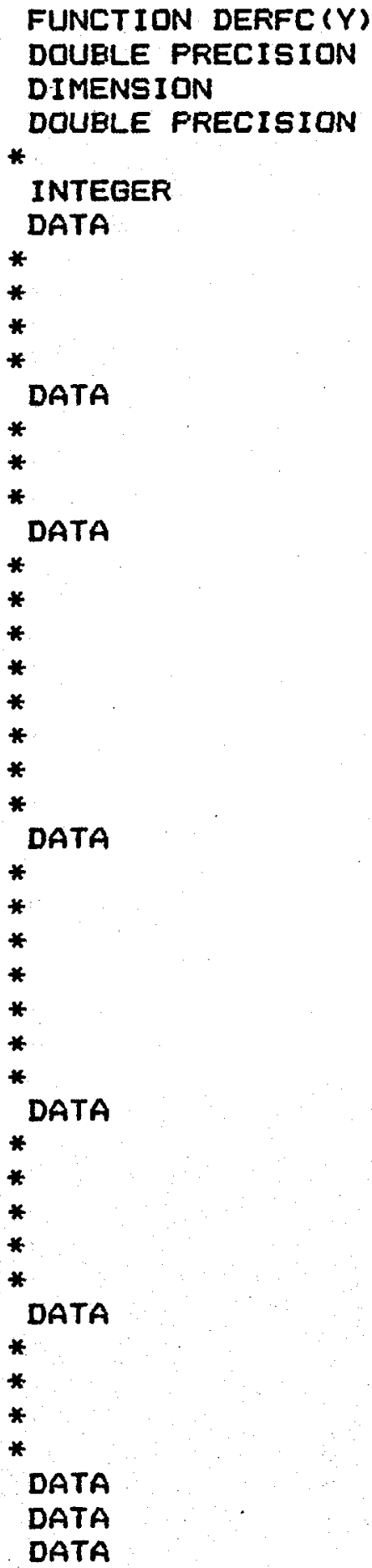

DERFC, $Y$

$P(5), Q(4), P 1(9), Q 1(8), P 2(6), Q 2(5)$

$P, Q, P 1, Q 1, P 2, Q 2, X M I N, X L A R G E$, SQRP $I, X$, RES, XSQ, XNUM, XDEN, XI, XBIG ISW, I

$P(1) / 113.8641541510502 \mathrm{DO} /$, $P(2) / 377.485237685302000 /$, $P(3) / 3209.37758913846900 /$, $P(4) / .185777706184603200 /$, $P(5) / 3.16112374387056600 /$ Q(1) /244.0246379344442DO/, $Q(2) / 1282.616526077372 \mathrm{DO} /$, $Q(3) / 2844.236833439171 \mathrm{DO} /$, $Q(4) / 23.60129095234412 \mathrm{DO} /$

$P 1(1) / 8.88314979438837600 /$, $P_{1}(2) / 66.11919063714163 \mathrm{DO} /$, $P_{1}(3) / 298.635138197400100 /$, $P_{1}(4) / 881$. $9522212417691 \mathrm{DO} /$, P1 (5) /1712.04761263407100/, $P 1(6) / 2051.078377826071 \mathrm{DO} /$, $P_{1}(7) / 1230.33935479799700 /$, $P 1(8) / 2.153115354744038 D-8 /$, $P_{1}(9) / .564188496988670100 /$ Q1 (1)/117.693950891312500/, Q1 (2) /537.181101862009900/, Q1 (3) / $1621.389574566690 \mathrm{DO} /$, Q1 (4) /3290.799235733460DO/, Q1 (5) /4362.61909014324700/, Q1 (6) /3439.36767414372200/, Q1 (7) /1230.33935480374900/, Q1 (8)/15.74492611070983DO/

P2(1)/-3.603448999498044D-01/, $P 2(2) /-1$.257817261112292D-01/, $\mathrm{P} 2(3) /-1.608378514874228 \mathrm{D}-02 /$, $P 2(4) /-6.587491615298378 D-04 /$, $P 2(5) /-1.631538713730210 D-02 /$, P2 (6) $/-3.053266349612323 \mathrm{D}-01 /$ $\mathrm{Q2}(1) / 1.872952849923460 \mathrm{DO} /$, Q2 (2) /5.279051029514284D-01/, Q2 (3) /6.051834131244132D-02/, 02 (4) /2.335204976268692D-03/, Q2(5)/2.568520192289822DO/ XMIN/1. OD-10/, XLARGE/6.375DO/ XBIG/13.3DO/ SQRPI/.5641895835477563DO/ 


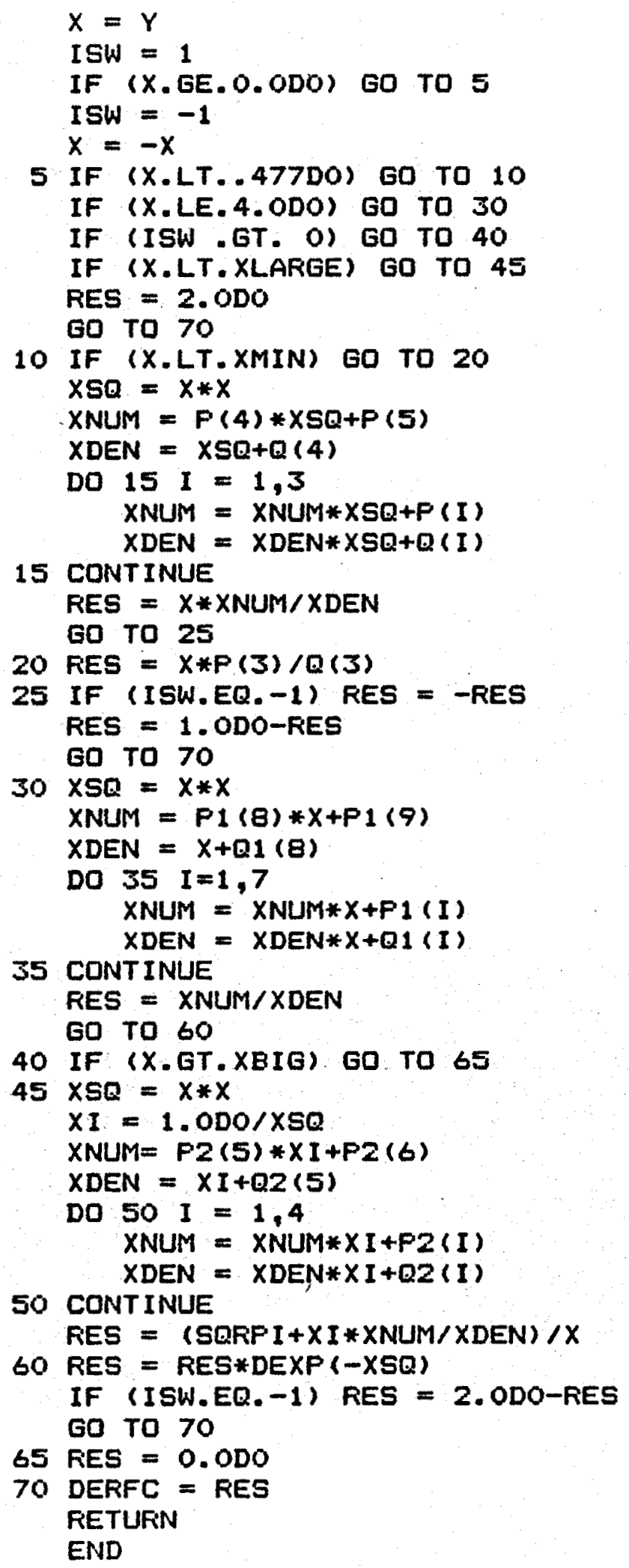


SUBROUTINE VAFPFI (L, NL, N, NMAX, LPPZ, IV, T, Y, W, ADA, A, $X$ IPRINT, ALF, BETA, IERR, ITMAX)

DOUBLE PRECISION A (NMAX, LPF2), BETA(L), ALF (NL), T (NMAX, IV), $2 W(N), Y(N), A C U M, E P S 1$, GNSTEP, NU, PRJRES, R, RNEW, XNORM,

2 AS, BS, S

INTEGER B1, OUTPUT

LOGICAL SKIP

EXTERNAL ADA

DATA EFS1/1.D-6/, OUTFUT/6/

IERR $=1$

ITER $=0$

$L P 1=L+1$

$B 1=L+2$

LNL2 $=L+N L+2$

NLP1 $1=N L+1$

SKIP $=$.FALSE.

MODIT = IPRINT

IF (IPRINT . LE. O) MODIT = ITMAX + 2

NU $=0$.

$N U=1$.

5 CALL DPA (L, NL, N, NMAX, LFPZ, IV, T, Y, W, ALF, ADA, IERR,

$X$ IPRINT, $A, B E T A, A(1, L P 1), R)$

GNSTEP $=1.0$

ITERIN $=0$

IF (ITER . GT. O) GO TO 10

IF (NL . EQ. O) GO TO 90

IF (IERR . NE. 1) GO TO 99

IF (IFRINT .LE. O) GO TO 10

WFITE (DUTPUT, 207) ITERIN, $R$

WRITE (OUTPUT, 200) NU

10 CALL OFFAC1 (NLP1, NMAX, N, L, IPRINT, A(1, B1), FRJFES, IERFi)

IF (IERR . LT. O) GO TO 99

IERR $=2$

IF (NU .EQ. O.) GD TO 30

25 CALL ORFAC2 (NLP1, NMAX, NU, A(1, B1))

30 CALL BACSUB (NMAX, NL, $A(1, B 1), A(1, L N L 2)$ ) DO $35 K=1$, NL

$A(K, B 1)=A L F(K)+A(K, L N L 2)$

35

40

$\mathrm{x}$

CALL DPA (L, NL, N, NMAX, LFPZ, IV, T, Y, W, A(1, B1), ADA,

IERR, IPRINT, $A$, BETA, A (1, LPI), FNEW)

IF (IERR .NE. 2) GO TO 99

ITER = ITER + I

ITERIN = ITERIN + 1

SKIF = MOD (ITER, MODIT) . NE. 0

IF (SKIP) GO TO 45

WRITE (QUTPUT, 203) ITER

WRITE (OUTPUT, 216) (A(K, B1), $K=1, N L)$

WRITE (OUTPUT, 207) ITERIN, FINEW

45 IF (ITER . LT. ITMAX) GO TO 50

IERR $=-1$

CALL VARERR (IFRINT, IERR, 1)

GO TO 95

50 IF (RNEW - R .LT. EPS1* $(R+1 . D O))$ GO TO 75

IF (NU.NE. O.) GO TO 60

GNSTEF $=0.5 *$ GNSTEP

IF (GNSTEF . LT. EPS1) GO TO 95

DO $55 K=1, N L$ 
55

$$
\text { GO } \mathrm{ACK}, \mathrm{BO}
$$

60

$\mathrm{NU}=1.5 * \mathrm{NU}$

IF (.NOT. SKIF) WFITE (OUTFUT, 206) NU

IF (NU .LE. 100.) GO TO 65

IERR $=-2$

CALL VARERR (IPRINT, IERR, 1)

GO TO 95

65

DO $70 K=1, \mathrm{NL}$

$K S U B=L P 1+K$

DO $70 \mathrm{~J}=K, \mathrm{NLP1}$

JSUB $=$ LP $_{1}+\mathrm{J}$

ISUB $=$ NLPI $1+J$

70

$A(K, J S U E)=A(I S U B, K S U E)$

$75 \mathrm{R}=\mathrm{RNEW}$

GO TO 25

DO $80 K=1, N L$

$80 \quad A L F(K)=A(K, B 1)$

ACUM $=$ GNSTEP*XNORM(NL, A(1, LNL2) $) / X N O R M(N L, A L F)$

IF (ITERIN .EQ. 1) $N U=0.5 * N U$

IF (SKIF) GO TO 85

WRITE (OUTPUT, 200) NU

WFITE (OUTFUT, 208) ACUM

Q5 IERR $=3$

IF (FRJRES . GT. EPS1*(R + 1.DO)) GO TO 5

90 IERR = ITER

95 IF (NL . GT. O) CALL DFA(L, NL, N, NMAX, LFF2, IV, T, Y, W, ALF, $X$ ADA, 4, IPRINT, $A, B E T A, A(1, L P 1), R)$

CALL POSTPFIL, NL, N, NMAX, LNL2, EFS1, R, IFRINT, ALF, W, A,

$X A(1, L P 1), B E T A$, IERR)

99 RETURN

200 FORMAT (9H NU $=, E 15.7$ )

203 FORMAT (12HO ITERATION, I4, 24H NONLINEAR PARAMETERS)

206 FORMAT (25H STEP RETRACTED, NU $=$, E15.7)

207 FDRMAT ( 1 HO, IS, $20 \mathrm{H}$ NOFM OF RESIDUAL $=$, E15.7)

208 FORMAT (34H NOFM (DELTA-ALF) / NORM (ALF) =, E12.3)

216 FORMAT (1HO, TE15.7)

END

C

SUBFOUT INE DFFAC1 (NLF1, NMAX, N, L, IFRINT, B, FFIJFES, IEFR)

DOUBLE PRECISION ACUM, ALFHA, B(NMAX, NLP1), BETA, DSIGN, FRJRES,

C

$X U, X N O F M, A S, B S, S$

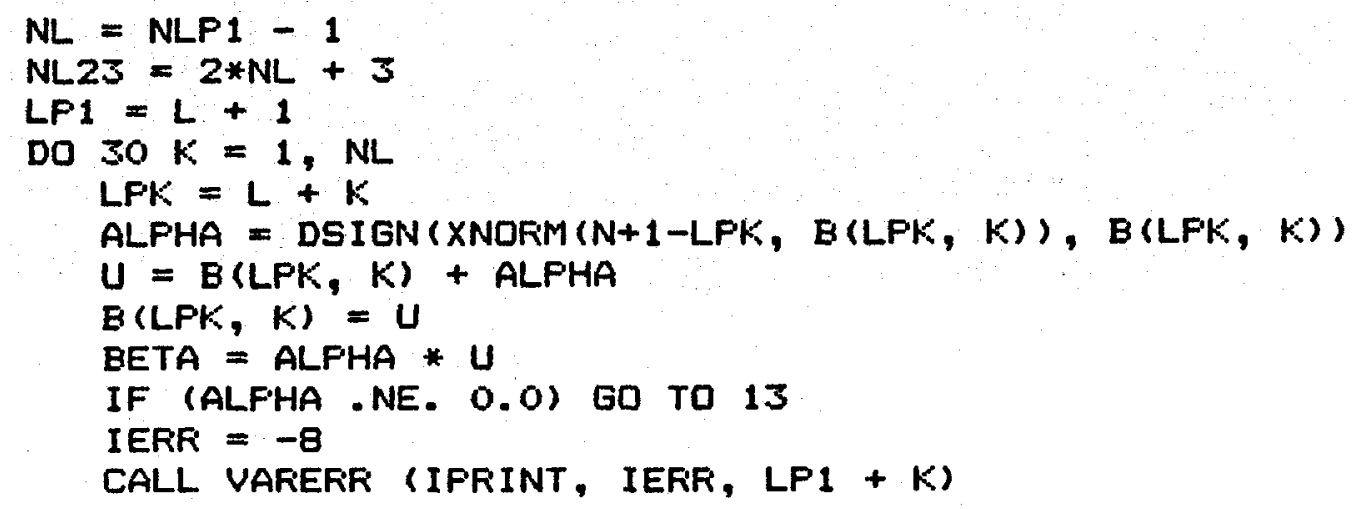




$$
\text { GO TO } 99
$$

$$
K F_{1}=K+1
$$

DO $25 \mathrm{~J}=K \mathrm{P}_{1}, \mathrm{NLP1}$

ACUM $=0.0$

DO $20 I=$ LPK, $N$

20

$A C U M=A C U M+B(I, K) * B(I, J)$

$A C U M=A C U M /$ BETA

DO $25 I=L F K, N$

25

$B(I, J)=B(I, J)-B(I, K) * A C U M$

$30 \quad B(L P K, K)=-A L F H A$

PRJRES = XNORM (NL, B(LP1, NLF1))

IF (IERR .EQ. 4) GO TO 99

DO $50 K=1, \mathrm{NL}$

$L P K=L+K$

DO $40 \mathrm{~J}=K$, NLP1

JSUE $=$ NLP1 $+J$

$B(K, J)=E(L P K, J)$

$40 \quad B(J S U B, K)=B(L F K, J)$

50 $\quad B(N L 23, K)=\operatorname{XNORM}(K, B(L P 1, K))$

99 RETURN

END

C

SUBRDUT INE ORFAC2 (NLP1, NMAX; NU, B)

DOUBLE PRECISION ACUM, ALPHA, B(NMAX, NLP1), BETA, DSIGN, NU, $U$,

$X$ XNORM, AS, BS, S

$N L=N L P 1-1$

$N L 2=2 * N L$

$N L 23=N L 2+3$

DO $30 K=1$, NL

$K P 1=K+1$

NLPK $=N L+K$

NLPKM1 $=$ NLPK -1

$B(N L P K, K)=N U * B(N L 23, K)$

$B(N L, K)=B(K, K)$

ALPHA $=\operatorname{DSIGN}(X \operatorname{NOFM}(K+1, B(N L, K)), B(K, K))$

$U=B(K, K)+A L F H A$

BETA = ALFHA *U

$B(K, K)=-A L P H A$

DO $30 \mathrm{~J}=K P 1, N L P 1$

$B(N L P K, J)=0$.

$A C U M=U * B(K, J)$

20

DO $20 I=$ NLP1, NLPKM 1

$A C U M=A C U M+B(I, K) * B(I, J)$

$A C U M=A C U M /$ BETA

$B(K, J)=B(K, J)-U * A C U M$

30

DO $30 I=N L P 1, N L P K$

RETURN

$B(I, J)=B(I, J)-B(I, K) * A C U M$

C END

SUEROUTINE DPA \&L, NL, N, NMAX, LFPZ, IV, T, Y,W, ALF, ADA, ISEL, $X$ IPRINT, $A, U, R$, RNORM)

DOUELE PRECISION A(NMAX, LPP2), ALF (NL), T(NMAX, IV), $W(N), Y(N)$, $X$ ACUM, ALPHA, BETA, RNORM, DSIGN, DSQRT, SAVE, R(N), U(L), XNORM,

$X$ AS, BS, S

INTEGER FIRSTC, FIRSTR, INC (12, 8)

LOGICAL NOWATE, PHILP1

EXTERNAL ADA 
IF (ISEL . NE. 1) GO TO 3

$L F 1=L+1$

$L N L 2=L+2+N L$

$L P 2=L+2$

LPP1 $=$ LPP2 - 1

FIRSTC $=1$

LASTC = LPP 1

FIRSTR = LPI

CALL INIT (L, NL, N, NMAX, LPP2, IV, $T, W, A L F, A D A, I S E L$,

$X$ IPRINT, $A$, INC, NCON, NCONP1, PHILP 1, NOWATE)

IF (ISEL.NE. 1) GO TO 99

GO TO 30

3 CALL ADA (LP1,NL, N, NMAX,LFF2, IV, A, INC, T, ALF, MINO (ISEL, 3))

IF (ISEL .EQ. 2) GO TO 6

FIRSTC $=$ LF2

LASTC $=$ LPP1

FIRSTR $=(4-$ ISEL $) * L+1$

GO TO 50

6 FIRSTC $=$ NCONP 1

LASTC = LPI

IF (NCON . EQ. O) GO TO 30

IF (A 1, NCON) .EQ. SAVE) GO TO 30

ISEL $=-7$

CALL VARERR (IFRINT, ISEL, NCON)

GO TO 99

30 IF (FHILF1) GO TO 40

DO $35 I=1, N$

$35 \quad R(I)=Y(I)$

GO TO 50

40 DO $45 I=1, \mathrm{~N}$

$45 \quad R(I)=Y(I)-R(I)$

SO IF (NOWATE) GO TO 58

DO $55 . I=1, N$

$A C U M=W(I)$

DO $55 \mathrm{~J}=$ FIRSTC, LASTC

55

$A(I, J)=A(I, J) * A C U M$

58 IF (L . EQ. O) GO TO 75

DO $70 K=1$, L

$K P 1=K+1$

IF (ISEL .GE. 3 .OR. (ISEL .EQ. 2 .AND. K .LT.NCONF1)) GO TO 66

$A L P H A=D S I G N(X N O R M(N+1-K, A(K, K)), A(K, K))$

$U(K)=A(K, K)+A L P H A$

$A(K, K)=-A L P H A$

FIRSTC $=$ KP1

IF (ALPHA . NE. 0.0 ) GO TO 66

ISEL $=-8$

CALL VARERR (IFFINT, ISEL, $K$ )

GO TO 99

66 $\quad B E T A=-A(K, K) * U(K)$

DO $70 \mathrm{~J}=$ FIFSTC, LASTC

$A C U M=U(K) * A(K, J)$

DO $68 I=K P 1, N$

68. $\quad A C U M=A C U M+A(I, K) * A(I, J)$

ACUM = ACUM / BETA

$A(K, J)=A(K, J)-U(K) * A C U M$

DO $70 I=K P I, N$ 


$$
A(I, J)=A(I, J)-A(I, K) * A C U M
$$

75 IF (ISEL . GE. 3) GO TO 85

RNOFM $=$ XNORM $(N-L, R(L F 1)$

IF (ISEL .EQ. 2) GO TO 99

IF (NCON . GT. O) SAVE $=A(1, N C D N$ )

85 IF (L.GT. O) CALL BACSUB (NMAX, L, $A, R$ )

DO $95 I=F I F S T R, N$

IF (L. EQ. NCON) GO TO 95

$M=L F 1$

DO $90 K=1, N L$

$A C U M=0$.

DO $88 \mathrm{~J}=$ NCONP $1, L$

IF (INC(K, J) .EQ. O) GO TO $8 Q$

$M=M+1$

88

$A C U M=A C U M+A(I, M) * R(J)$

90 CONT INUE

KSUB $=$ LPI $1+K$

IF (INC(K, LPI) .EQ. O) GO TO 90

$M=M+1$

$A C U M=A C U M+A(I, M)$

95

$A(I, K S U B)=A C U M$

99 RETURN

$A(I, L N L 2)=R(I)$

END

C

SUEROUTINE INIT IL, NL, N, NMAX, LFF2, IV, T, $W, A L F, A D A, I S E L$, $X$ IPRINT, $A$, INC, NCON, NCONF1, FHILP1, NOWATE)

DOUELE FRECISION A(NMAX, LPF2), ALF (NL), T(NMAX, IV), $W(N)$,

$X$ DSQRT, AS, BS, S

INTEGER QUTPUT, $P, \operatorname{INC}(12,8)$

LOGICAL NOWATE, PHILP1

EXTEFINAL ADA

DATA OUTPUT $16 /$

$L F 1=L+1$

$L N L 2=L+2+N L$

IF (L . GE. 0 . AND. NL . GE. 0 . AND. L+NL .LT. $N$. AND. LNL2 . LE.

$X$ LFF2 - AND. $2 * N L+3$. LE. NMAX . AND. N . LE. NMAX . AND.

$X$ IV .GT. O .AND. .NOT. (NL .EQ. O .AND. L .EQ. O) GO TO 1 ISEL $=-4$

CALL VAFERR (IFRINT, ISEL, 1)

GO TO 99

1 IF (L .EQ. O .OR. NL .EQ. O) GO TO 3

DO $2 \mathrm{~J}=1$, LPI

DO $2 K=1, N L$

$2 \quad \operatorname{INC}(K, J)=0$

3 CALL ADA (LP1, NL, N, NMAX, LFF2, IV, A, INC, T, ALF, ISEL)

NOWATE $=$. TRUE.

DO $9 I=1, N$

NOWATE = NOWATE . AND. (W(I) .EQ. 1.0)

IF (W(I) .GE. O.) GO TO 9

ISEL $=-6$

CALL VAREFR (IPRINT, ISEL, I)

GO TO 99

$9 W(I)=\operatorname{DSQRT}(W(I))$

$N C O N=L$

NCONP1 $=$ LF 1

FHILP1 $1=L$ L.EQ. $O$

IF (FHILP1 .OR. NL . EQ. O) GO TO 99 


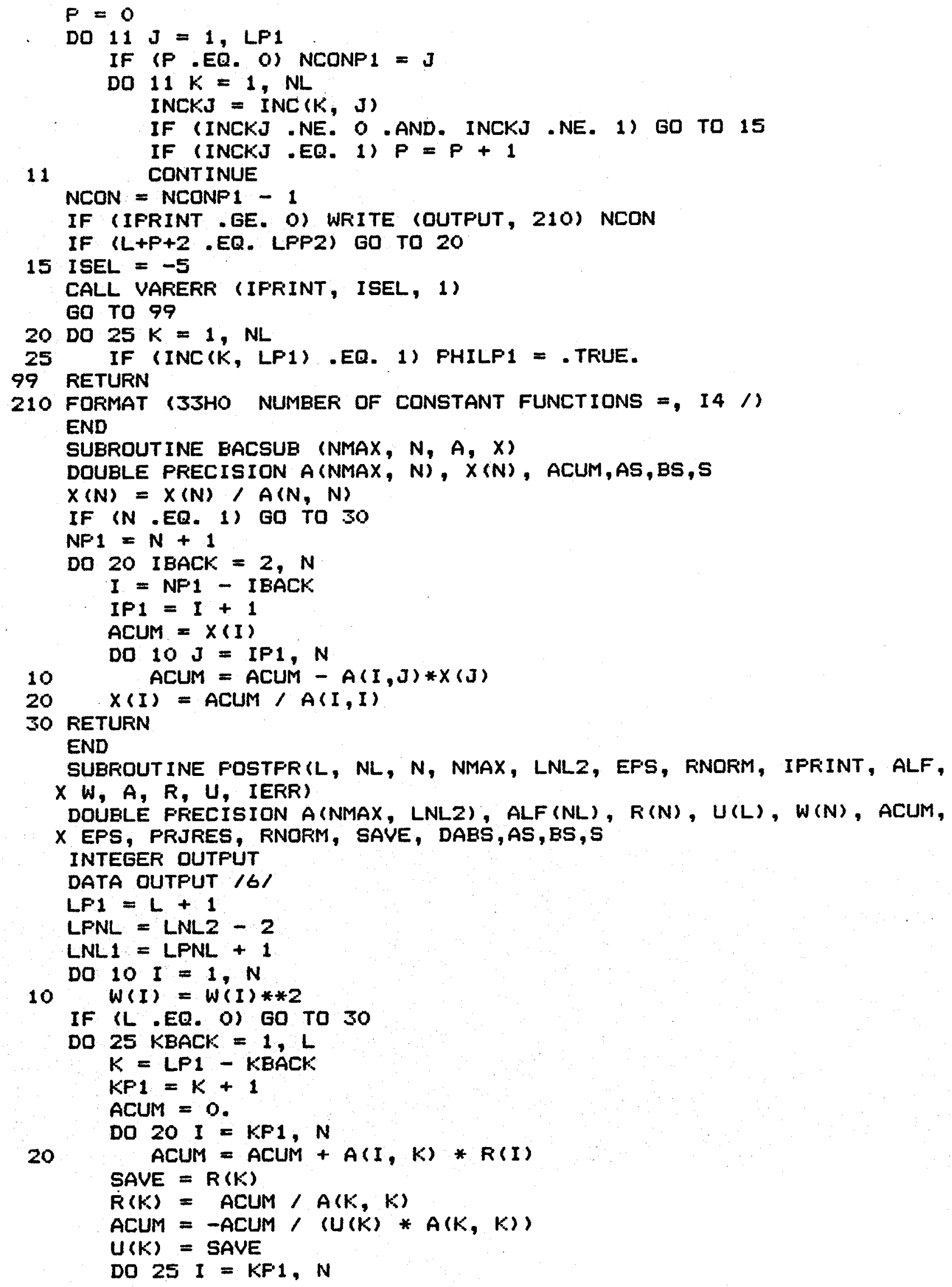




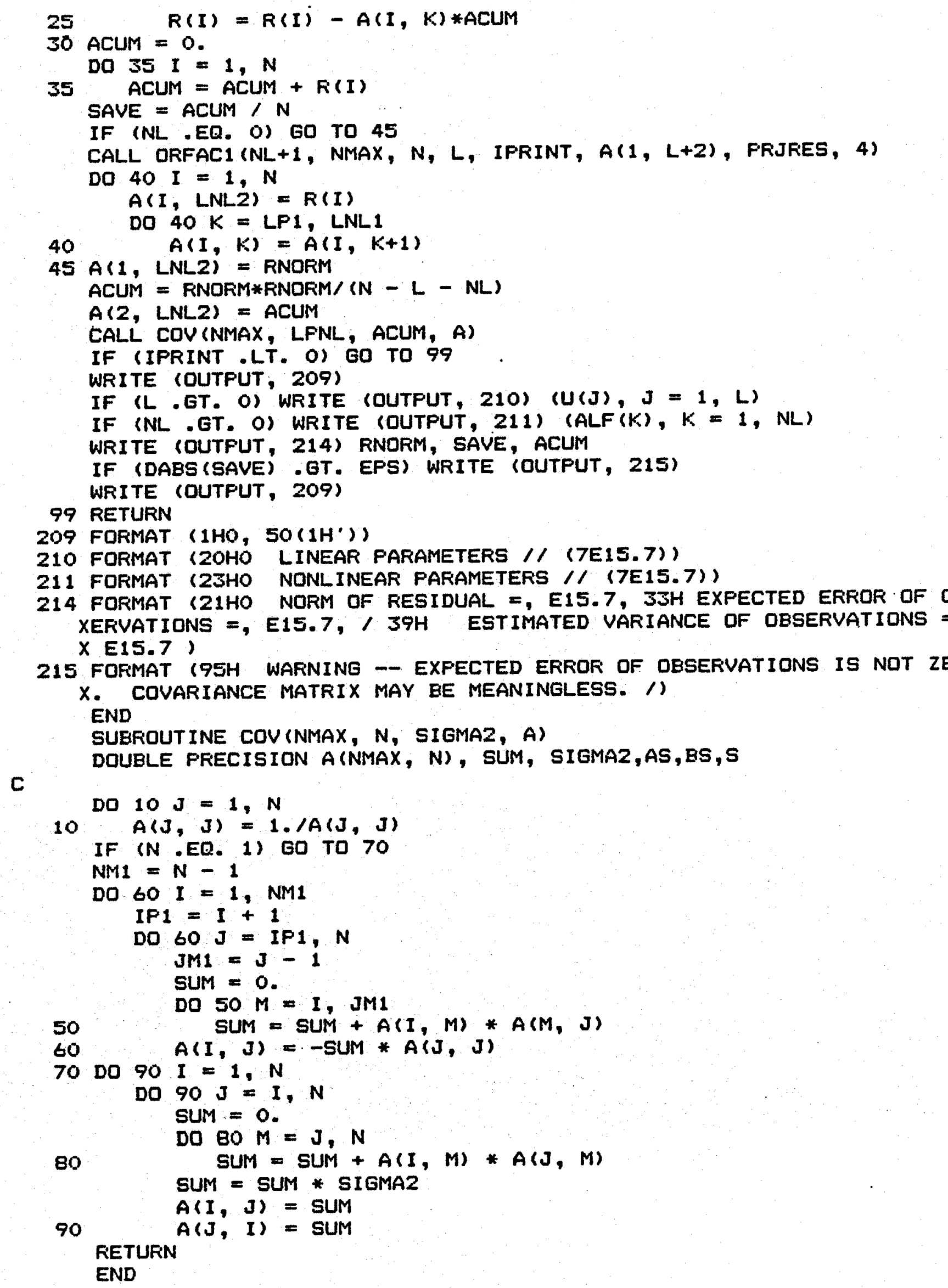


SUBROUTINE VARERF (IFFINT, IERR, K)

DOUBLE PRECISION AS,BS, $S$

INTEGER ERRND, DUTFUT

DATA OUTPUT / $/ 6 /$

IF (IPRINT .LT. O) GO TO 99

ERRND = IABS (IERR)

GO TO $(1,2,99,4,5,6,7,8)$, ERRNO

1 WRITE (OUTPUT, 101)

GD TO 99

2 WRITE (OUTPUT, 102)

GO TO 99

4 WRITE (OUTPUT, 104)

GO TO 99

5 WRITE (OUTPUT, 105)

GO TO 99

6 WRITE (OUTPUT, 106) $\mathrm{K}$

GO TO 99

7 WRITE (OUTPUT, 107) K

GO TO 99

8 WRITE (OUTPUT, 108) $K$

99 RETURN

101 FORMAT (46HO FROBLEM TERMINATED FOR EXCESSIVE ITERATIONS //)

102 FORMAT (49HO PROBLEM TERMINATED BECAUSE OF ILL-CONDITIONING / $/$ )

104 FORMAT (/ SOH INFUT EFROR IN FARAMETER L, NL, $N$, LFF2, DR NMAX. /)

105 FORMAT (6EHO ERROR - - INC MATRIX IMFROPERLY SPECIFIED, OR DISAGRE XES WITH LPFZ. 11

106 FORMAT (19HO ERFOR -- WEIGHT (, I4, 14H) IS NEGATIVE. $/$ )

107 FORMAT (28HO ERROR - CONSTANT COLUMN, I3, 37H MUST BE COMPUTED XONLY WHEN ISEL $=1$. $/$

108 FOFMAT (33HO CATASTROFHIC FAILURE -- COLUMN, I4, 28H IS ZEFO, SE

XE DOCUMENTATION. $/)$

END

DOUBLE FRECISION FUNCTION XNORM $(N, X)$

DOUBLE PRECISION $X(N)$, RMAX, SUM, TERM, DABS, DSQRT

c

RMAX $=0$. FIND LARGEST (IN ABSOLUTE VALUE) ELEMENT

DO $10 I=1, N$

10. CONTINUE

IF (DABS $(X(I))$. GT. RMAX) FMAX $=\operatorname{DABS}(X(I))$

SUM $=0$.

IF (RMAX .EQ. O.) GO TO 30

DO $20 I=1, N$

TERM $=0$.

IF (RMAX + DABS $(X(I)$ ). NE. RMAX) TERM $=X(I) / R M A X$

20 SUM $=$ SUM + TERM*TERM

30 XNORM $=$ RMAX *DSQRT (SUM)

99 RETURN

END 


\section{APPENDIX E: EIECTRODE MOUNTING PROCHDURE}

1. Drill .250 in. hole in plate.

2. Measure electrode 0.D. with micrometer.

3. Using hand reamer with block to keep it aligned, ream hole so that the electrode can be press fit (if the fit is too tight. the electrode will deform and be wasted).

4. Clean electrode and hole with acetone.

5. Using the silver disc on the top of the electrode and the rubber hammer, tap the electrode part way into the plate.

6. Apply a bead of loctite cement around the electrode O.D.,

7. Tap electrode until it is flush with plate (+.0015 in.). A dial indicator can be used to check this tolerance.

B. Wipe clean with acetone. 


\section{APPENDIX F: MATERIALS SUPPLIERS}

The cast aluminum plate was purchased from Castle Metals, San Francisco, $321-2500$.

The plate was anodized at Sanford Metal Processing, Menlo Park, 327-5172.

The float glass was purchased at Acme Glass, Palo Alto, 321-7781.

If thicker, pyrex glass is desired, try Heussner Optics, Santa Clara, 9884214.

The brass parts used to construct the electrodes were purchased at Don's Hobby shop, Menlo Park. 322-7176.

The electrodes were gold plated at Hansen Labs, on campus. 